\title{
22. PLANKTONIC FORAMINIFERS AND CALPIONELLIDS FROM GULF OF MEXICO SITES, DEEP SEA DRILLING PROJECT LEG 77
}

\author{
Isabella Premoli Silva, Dipartimento di Scienze della Terra, Università di Milano, via Mangiagalli, 34, Milan, Italy \\ and \\ Charles L. McNulty, Department of Geology, University of Texas at Arlington, Arlington, Texas
}

\begin{abstract}
Drilling on Leg 77 resulted in eight single-bit holes at five sites extending across the Yucatan Channel in the southeastern Gulf of Mexico. Sites 535, 539 (aborted hole of $7.5 \mathrm{~m}$ depth), and 540 were grouped as basin sites, whereas location on up-faulted blocks at Sites 536,537 , and 538 led to their grouping as basement sites.

The sedimentary record encountered across the Channel is short, intermittent, and laterally erratic, reflecting both the general instability of sedimentation and the depositional contrast between basin and basement sites. The combined record for the Cenozoic is incomplete, and that for most of the Upper Cretaceous is missing. The Lower Cretaceous record is relatively long at basin sites, including apparent Berriasian at Site 535, but the record is still discontinuous and the biostratigraphic data are sparse, frequently contradictory, and complicated by displacement and reworking. The Lower Cretaceous record is again short and erratic at the basement Sites 536, 537, and 538, where displaced shelf grainstones, with very poor recovery, and variably minor interbedded lime mudstones and marls lie on continental basement.

Cenozoic cores are mostly pelagic calcareous oozes, except at Site 535 , where more than $150 \mathrm{~m}$ of upper Pleistocene distal fan and deltaic mudstones were drilled. The Cenozoic successions are thin, fragmentary, and variable laterally, except for the Oligocene, which is well developed in basin Hole 540 and basement Hole 538A. Planktonic foraminifers are typically abundant and well preserved, but reworking is persistent. No Cenozoic except Pleistocene was encountered at basin Site 535. The Cretaceous/Tertiary boundary was recovered in Hole 536, where a complete foraminiferal zonal sequence of the lowermost Paleocene overlies ill-defined Maestrichtian without perceptible lithic change.

The Maestrichtian through Turonian interval is represented by only a few meters at Sites 540, 536, 537, and 538, and ranges from upper Maestrichtian to Santonian. Nannofossil-foraminiferal chalk is typical, but volcanogenic sandstone and coarse bioclastic limestone also occur in relative abundance. No record of this interval was found at Site 535. The Cenomanian is missing at basement Sites 536, 537, and 538, but is thick and gradational into the Albian at basin Sites 535 and 540 . The passage into the Albian at Site 540 is accompanied by a change from coarse skeletal to pelagic limestones. The Cenomanian and Albian of Site $535(535-17, \mathrm{CC}$ to $535-43, \mathrm{CC})$ form a continuous, mystifying succession that may be a huge slump or canyon fill.

The Lower Cretaceous of basin sites differs markedly from that of basement sites. At the latter, the Albian to Aptian displaced shelf grainstones and minor interbeds of lime mudstone are typical. Rare calpionellids in grainstone matrix, displaced trocholinid grains, and rare planktonic specimens in interbeds and grainstone matrix provide approximate ages for layers proximal to the basement, layers which range from upper Aptian (Site 536) to Valanginian (Site 537) and Berriasian (Hole 538A).

The Cretaceous of Site 535 is the most complex of the major intervals drilled during Leg 77. The sequence from 535-17, CC, at the base of the Pleistocene, through Section 535-42-2 $(240 \mathrm{~m})$ is composed of laminated limestones with some discrete biogenic turbidites and uncommon marly interbeds. Displaced and reworked biogenic materials are common, particularly in the turbidites, but definitely autochthonous planktonic foraminifers are infrequent and rare. Those found indicate a normal succession of middle and lower Albian foraminiferal zones, but rare ammonitic material indicates that the interval is Cenomanian to upper Albian. This contradiction, the extensive reworking, and the rare, small size-graded planktonic foraminifers undermined the validity of the planktonic zones and raised the possibility of an exotic origin of the interval.

At Core 535-43 the lithofacies changes to seemingly autochthonous limestone and marls with periodic dark organic and pyritic marls, which continue to total depth at Core 535-79. Small recrystallized planktonic foraminifers are common in indurated limestones at the top (Cores 535-43 to 535-47), indicating an Aptian succession, but planktonic specimens are tiny and rare below. Calpionellids appear in Core 535-64 and become common to abundant in Core 535-71, below which calpionellid Zones E and D occur. Their temporal implications are contradicted, however, by rare Globuligerina and Trocholina, which suggest a lesser age than that implied by the calpionellids, and in turn undermine the ages inferred for the medial part of the interval. In the end, the discontinuous but normal succession of planktonic foraminifer and calpionellid zones identified for the Cretaceous of Site 535 during shipboard and early post-cruise work has become suspect; and the composition of the sedimentary record, the nature of the depositional environment, and the possible structural effects are uncertain.
\end{abstract}

\section{INTRODUCTION}

During Leg 77, marine sediment spanning the interval from Recent to lowermost Cretaceous was recovered from eight single-bit holes in the Yucatan Channel of

\footnotetext{
${ }^{1}$ Buffler, R. T., Schlager, W., et al., Init. Repts. DSDP, 77: Washington (U.S. Govt. Printing Office).
}

the southeastern Gulf of Mexico (Fig. 1). Sites 535, 539, and 540 are on the Florida side; Site 536 is on the Campeche side; Sites 535,539 , and 540 were considered basin sites; and Sites 536, 537, and 538 were considered basement sites because of their position on high-standing basement blocks.

Recent through Tertiary sediments are in general represented by calcareous oozes, except at Site 535, where 


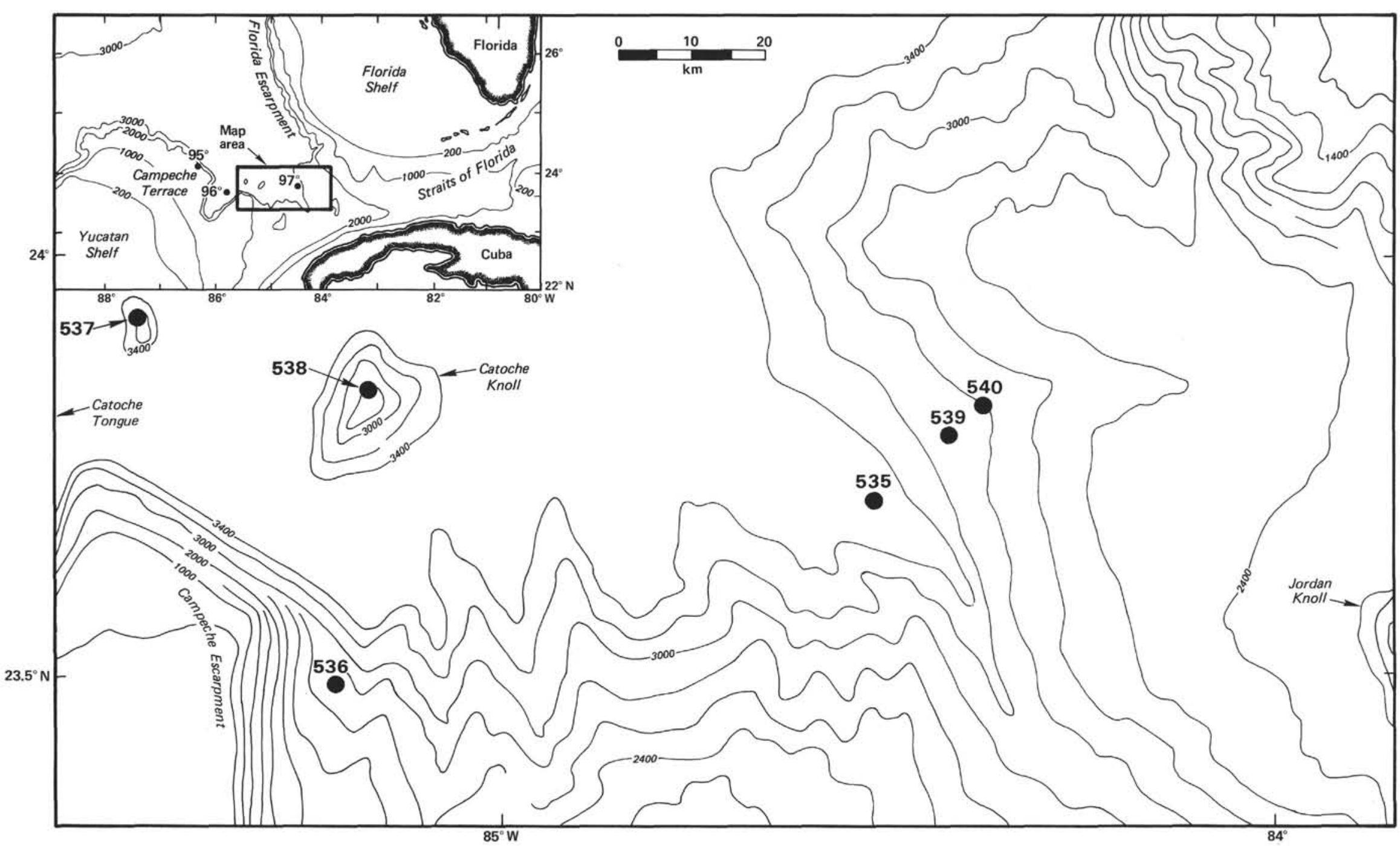

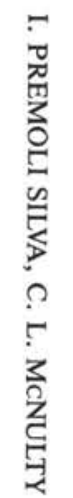

Figure 1. Map showing locations of sites drilled during Leg 77. Bathymetric contours in meters. 
over $150 \mathrm{~m}$ of poorly fossiliferous upper Pleistocene mudstone, representing the distal fan-delta deposits of the Mississippi River, were encountered. Very thin Upper Cretaceous pelagic chalk and/or limestone was penetrated at all sites, but most of the Cretaceous is composed of laminated and skeletal limestones of poor core recovery, poor fossil preservation, and both ecologically and temporally mixed populations.

Planktonic foraminifers are in general well preserved and show little sign of dissolution in the Tertiary and the brief uppermost Cretaceous, but they are mainly poorly preserved and size-sorted in the older Cretaceous sediments. Preservation of calpionellids varies from level to level, but is generally fair to good.

Long hiatuses are conspicuous features of all holes. Most of the Neogene and Upper Cretaceous are missing; shorter gaps also occur in the Paleogene and Lower Cretaceous. A few hardgrounds and some discrete slumpings also affected the sedimentary sequences, further complicating the biostratigraphic signal.

\section{BIOSTRATIGRAPHY}

Major difficulties were encountered in dating the Cretaceous sediments, because of their resedimented character and displaced and/or reworked faunal content (see also Sliter and Premoli Silva, this volume). Because the correct dating of the Early Cretaceous, both on basement high and in the deeper basins, was the key point for reconstructing the geological evolution of the Gulf of Mexico, this study is concentrated on the Cretaceous faunas. Only a few observations on the very incomplete Tertiary sequences will be added to the descriptions reported in the site chapters.

Planktonic foraminifer and calpionellid zonations used in the present paper are those included in the introductory part of this volume, to which the reader should refer.

\section{Holocene through Tertiary}

\section{Holocene}

The record of Holocene through Tertiary sediments recovered at all sites drilled during Leg 77 is plotted in Figures 2 and 3.

Only at Site $535(535-1-1,0-60 \mathrm{~cm})$ and in Hole 539A (539A-1-1, 0-135 cm) were present-day sediments recovered. At Site 535 they consist of $60 \mathrm{~cm}$ of a coarse, possibly graded, foraminifer-pteropod sand, which contains common terrestrial detritus as well as rich planktonic foraminifer and pteropod assemblages. Among the common planktonic foraminifers are Orbulina universa, Hastigerina siphoniphera, Globigerinoides ruber (pink), G. conglobatus, Globorotalia tumida, G. cultrata group, Pulleniatina sp., etc. At all other sites present-day sediments, if present, could not be separated from the underlying Pleistocene.

\section{Pleistocene}

Uppermost Pleistocene planktonic foraminiferal faunas were identified at all drill sites except Site 538, but they occur in two different lithologies: (1) nannofossil mud and marly ooze of upper slope (Sites 539 and 540) and of middle slope (Sites 536, 537, and 538), and (2) a turbiditic clay to sand of a canyon at the base of the Florida Escarpment (Site 535). Planktonic foraminiferal assemblages are very rich, and specimens are well preserved in the oozes. The turbiditic sand and clay yielded planktonic faunas of variable abundance, often sizesorted, poorly preserved, and containing reworked Miocene and Pliocene planktonic foraminifers and common shallow-water debris. The thickness of upper Pleistocene sediments varies with lithology, from $10 \mathrm{~cm}$ to about $6 \mathrm{~m}$ for the nannofossil mud and marly ooze to over $150 \mathrm{~m}$ for the turbidites.

The planktonic foraminiferal faunas consist mainly of tropical forms such as large Globorotalia tumida, $G$. cultrata group, Pulleniatina finalis, Hastigerina siphoniphera, and Globigerinoides ruber. However, at Site 535 (Samples 535-3-4, 15-18 cm and 535-5-4, 114-116 $\mathrm{cm}$ ), in Hole 539 (Sample 539-1,CC), and in Hole 539A (539A-1-1, $136 \mathrm{~cm}$ to 539A-2-2, $78 \mathrm{~cm}$ ), tropical forms are missing, and the assemblages are dominated by cooler-water species such as left-coiled Globorotalia truncatulinoides, Neogloboquadrina dutertrei, and N. pachyderma.

At all the drill sites, uppermost Pleistocene sediments rest unconformably on much older sediments. The hiatus varies from about $2 \mathrm{Ma}$ in Hole 539 to about $100 \mathrm{Ma}$ at Site 535 .

\section{Pliocene}

The youngest sediments below the hiatus were recovered in Hole $539(539-2-2,130 \mathrm{~cm}$ to $539-2-3,60 \mathrm{~cm})$, and are uppermost Pliocene. The 80 -cm-thick foraminifer-nannofossil ooze contains a rich, well-diversified planktonic foraminiferal fauna attributable to the youngest Pliocene zone (MPL6 = top N21), which agrees with the age inferred from the calcareous nannofossils. It is worth mentioning that in Hole 539, as in the Mediterranean, Globorotalia truncatulinoides appears below the Pliocene/Pleistocene boundary; consequently, its entrance was a late Pliocene event (personal communication, Sprovieri and Rio, 1982).

Older Pliocene faunas were found only in nannofossil-foraminifer ooze, and were recovered from the following holes (young to old):

1. Hole 538A: Interval $1-1,12-53 \mathrm{~cm}$ is upper Pliocene Zone MPL4 ( = top N19), on the basis of the concurrence of Globorotalia puncticulata and Sphaeroidinellopsis spp. and the absence of Globorotalia margaritae. The $41 \mathrm{~cm}$ rest unconformably on about $4 \mathrm{~m}$ (538A-1-1, $54 \mathrm{~cm}$ to $538 \mathrm{~A}-1-4,10 \mathrm{~cm}$ ) of nannofossil ooze of lower Pliocene Zone MPL2 (= lower N19), characterized by Globorotalia margaritae and Globigerina nepenthes. Planktonic foraminiferal faunas are well preserved at the top of the interval, but become progressively more dissolved downward.

2. Site 537: Interval $537-1-2,0 \mathrm{~cm}$ to $537-1, \mathrm{CC}(5.30$ $\mathrm{m})$ yielded a rich planktonic foraminiferal fauna of the lower Pliocene Zone MPL2 (= lower N19). As in Hole 538A, specimens are affected by dissolution in the lower part of the interval. Below Core 537-1, a Core 537-H1 was washed from 7.0 to $54.5 \mathrm{~m}$ sub-bottom. Seven of the 13 samples from washed Core $537-\mathrm{H} 1$ yielded rich 


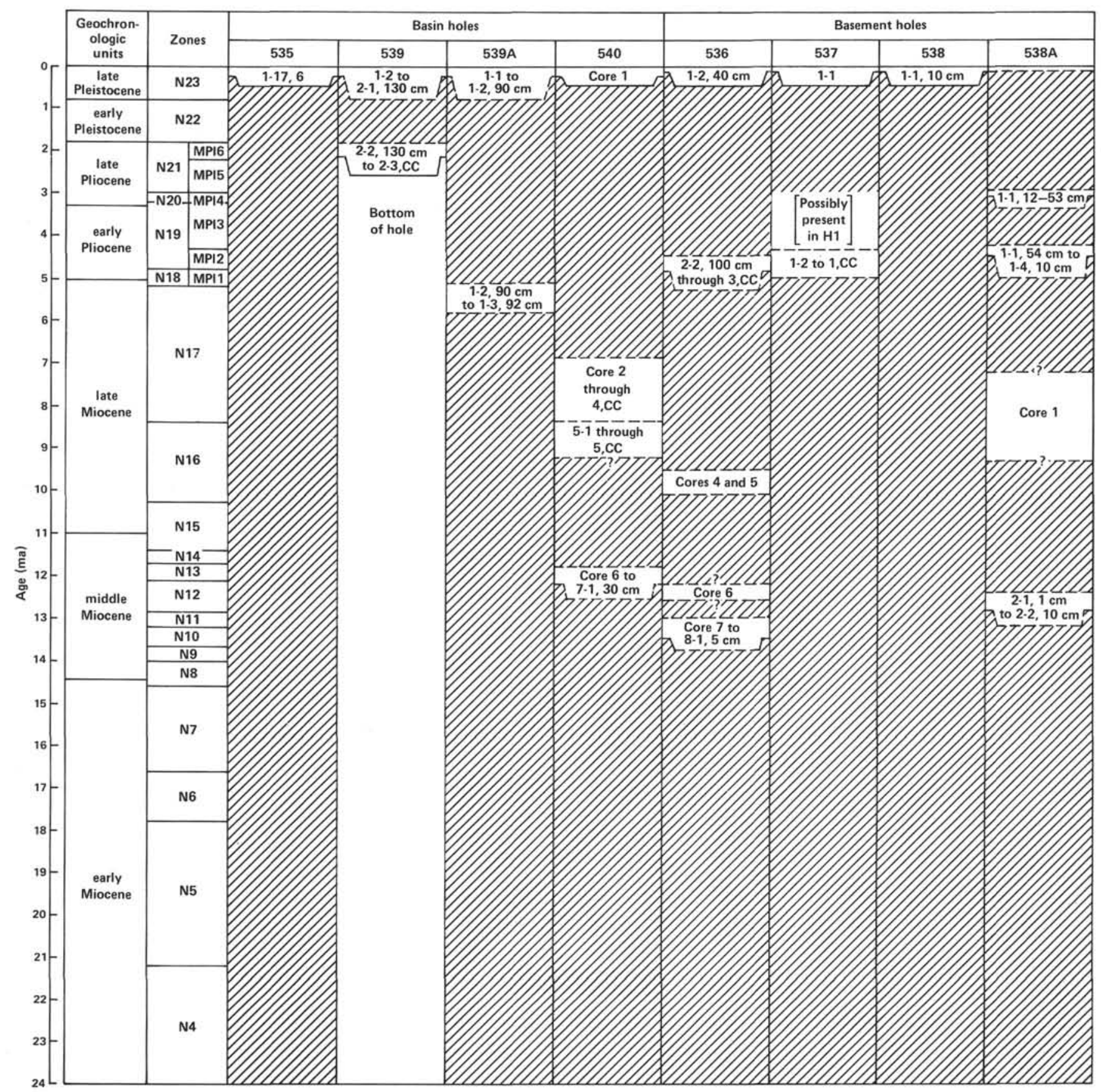

Figure 2. Age, geochronology, and foraminiferal zonation of Neogene sediments cored during Leg 77. Diagonal pattern $=$ hiatus.

planktonic foraminiferal assemblages of the upper Pliocene MPL4 and the lower Pliocene MPL3 zones, which are younger than the bottom of Core 537-1. Moreover, planktonic faunas attributable to these two zones were not recovered in Core 537-1. The remaining six samples from the lower part of the washed Core 537-H1 yielded generally well preserved planktonic faunal assemblages of the lower Pliocene MPL2 Zone, similar to those in Core 537-1. Some reworked faunas (mid-Miocene), detrital quartz, and biotite occur in Sample 537-H1-4, 5-7 cm. Such contradictory data suggest contamination from drilling procedure.
3. Site 536: The lower Pliocene MPL2 assemblage occurs from 536-2-2, $100 \mathrm{~cm}$ through 536-3-CC. Planktonic foraminiferal faunas are rich and well preserved. Characteristic species are Globorotalia margaritae, Globigerina nepenthes, and Sphaeroidinella dehiscens.

Pliocene sediments are completely missing at Sites 535 and 540 and in Holes 539A and 538A.

\section{Miocene}

The Miocene interval, almost $20 \mathrm{Ma}$ long, is very poorly represented on both sides of the Yucatan Channel. The entire Miocene is missing at Sites 535 and 537 


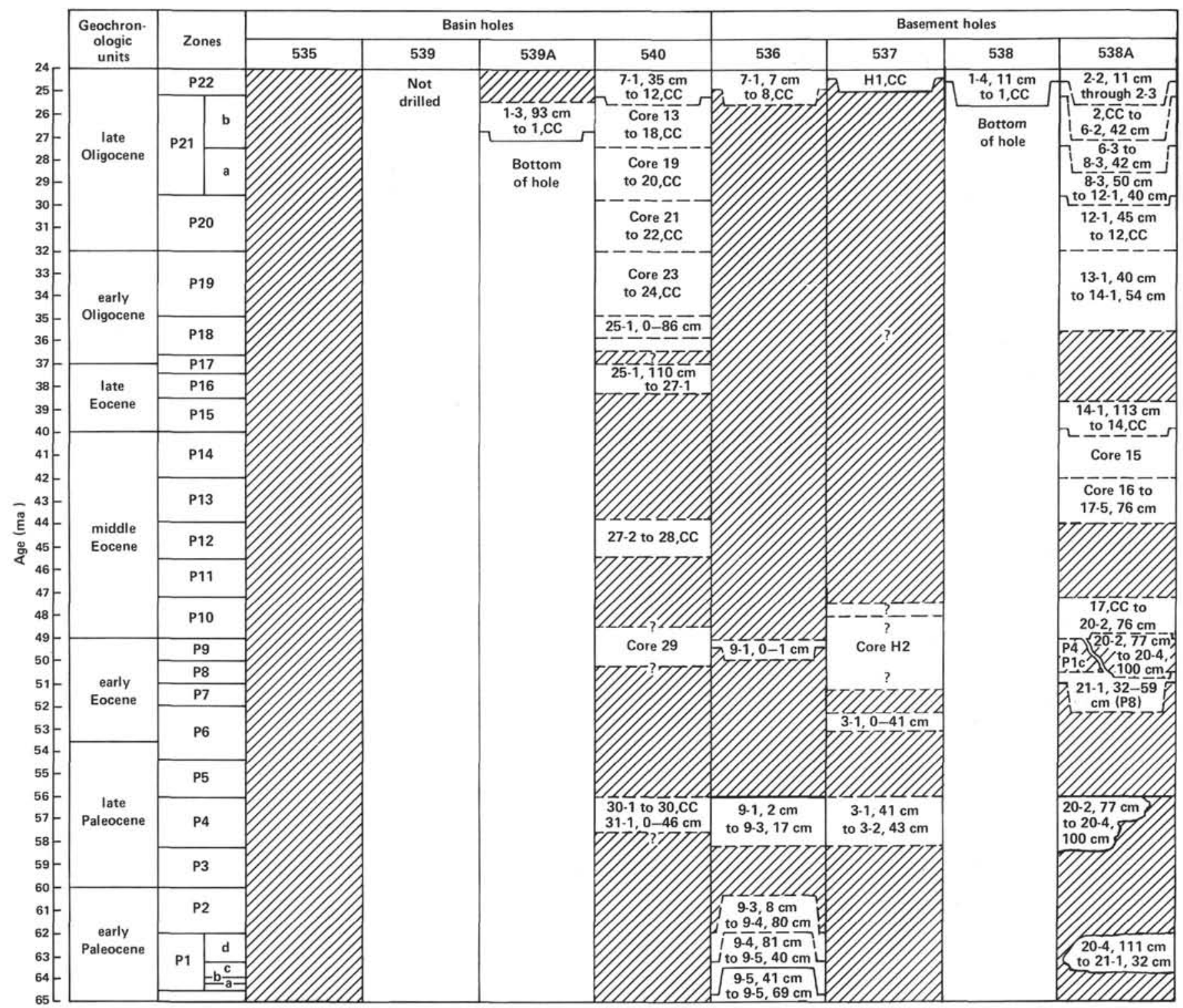

Figure 3. Age, geochronology, and foraminiferal zonation of Paleogene sediments cored during Leg 77. Diagonal pattern = hiatus.

and in Hole 538. In the remaining holes, the record is fragmentary for the upper and middle Miocene, and the lower Miocene is missing. Moreover, the upper and middle Miocene fragments encountered are of different ages, except for the middle upper Miocene from Holes 538A and 540 .

The youngest planktonic faunas of the Miocene belong to the top part of Zone N17, and include the N18/ N17 boundary in Hole 539A (539A-1-2, $90 \mathrm{~cm}$ to 539A$1-3,92 \mathrm{~cm}$ ). Planktonic faunas may be largely dissolved. Often the tests are filled with pyrite, which occurs also as isolated lumps or in burrows (Sample 539A-1-3, 8-10 $\mathrm{cm})$. Common species are primitive Globorotalia margaritae, G. plesiotumida, G. cultrata gr., G. scitula, Globigerina nepenthes, Globigerinoides extremus, G. peramplus, Neogloboquadrina acostaensis, and Sphaeroidinellopsis spp.

The lower part of Zone N17 and the top part of Zone N16, of the upper Miocene, were encountered at Site
540, from Core 540-2 through Core 540-5, and in Hole $538 \mathrm{~A}$ in Core 1 . At Site 540, planktonic foraminiferal assemblages are rich and diversified. Although largely dissolved in Cores 540-2 and 540-3, they become progressively better preserved downward. Common species present throughout the interval are Globorotalia merotumida, G. cultrata gr., Globoquadrina altispira, G. dehiscens, Neogloboquadrina acostaensis, $N$. humerosa, Globigerina nepenthes, and Sphaeroidinellopsis spp. Globorotalia plesiotumida appears in the lower part of Core $540-4$, marking the base of Zone N17. Volcanic glass, differently altered, occurs throughout. Some reworked mid-Miocene specimens and displaced shallow-water materials were encountered in Cores 540-4 and 540-5.

The core-catcher sample of Core 540-5 contains only a few fragments of foraminifers but a large amount of volcanic glass and clay.

The intensely deformed Core 1 in Hole 538A yielded the same foraminiferal assemblages as Site 540 , but they 
are admixed by drilling disturbances, and no boundary could be placed between Zones N17 and N16.

The oldest upper Miocene from all drill sites was recovered at Site 536 in Cores 536-4 and 536-5. This inter$\mathrm{val}$ is attributed to the older part of Zone N16, on the basis of concurrence in Core 536-4 of N. acostaensis and Globorotalia merotumida and the first representatives of Globigerinoides extremus and $N$. humerosa.

Considering all the sites together, a gap of a little less than 2 Ma separates the oldest upper Miocene from the youngest mid-Miocene.

Four zonal assemblages of the middle Miocene (Zones N13 to N10) could be identified from the drill sites, but they never occur in a regular sequence in a single hole. The record is as follows (from young to old):

Zone N13. Hole 540: Core 540-6 through 540-7-1, 30 $\mathrm{cm}$. The abundant, well-preserved planktonic foraminiferal assemblages contain Globorotalia fohsi, G. lobata, G. praemenardii, G. siakensis, common globoquadrinids, and Globigerinoides subquadratus. Volcanic glass, biotite, and a few radiolarians also occur throughout.

Zone N12 (top part). Hole 536: Core 536-6. Planktonic populations are very poor and mainly dissolved. Only a few species could be identified, including Globorotalia praemenardii, G. siakensis, Globoquadrina altispira, Neogloboquadrina continuosa, and Orbulina universa. The zonal attribution is inferred through correlation with nannofossil zonation. Glauconite is common to abundant, sometimes associated with large amounts of quartz $(536-6, C C)$ and fish debris.

Zone N12 (middle-lower part). Hole 538A: 538A-2-1, $1 \mathrm{~cm}$ to $538 \mathrm{~A}-2-2,10 \mathrm{~cm}$. Planktonic assemblages are well preserved and rich in diagnostic species, particularly the Globorotalia fohsi group.

Zones N11 to N10. Hole 536: Core 536-7 through $536-8-1,5 \mathrm{~cm}$. Planktonic foraminiferal assemblages contain a few Globorotalia praemenardii and G. peripheroacuta, common $G$. archaeomenardii and $G$. peripheroronda, Orbulina universa, rare Globorotalia praefohsi, and common globoquadrinids.

No lower Miocene sediments were recovered at any of the drill sites.

\section{Oligocene}

The late Oligocene was a time of deposition all over the southeastern Gulf of Mexico. The top part of Zone P22 was recovered in five holes out of seven on both sides of the Yucatan Channel. The top of the Oligocene is only a little older in Hole 539A (Zone P21b), but it and all of the Tertiary are missing at Site 535. The thickness of sediments attributable to Zone P22 varies from a few centimeters (Site 537, core-catcher sample of washed Core H1) to about $55 \mathrm{~m}(540-7-1,35 \mathrm{~cm}$ to $540-12, \mathrm{CC})$.

Planktonic foraminiferal faunas are rich and well preserved. Common species are the index species Globigerina angulisuturalis, G. ciperoensis, Globoquadrina praedehiscens, G. tripartita, G. baroemoenensis, G. altispira, Globorotalia siakensis, G. pseudokugleri, G. mendacis, and Globigerinoides primordius.

Below Zone P22 the record varies from site to site. Hole 538 was bottomed at that level. At Sites 536 and 537, uppermost Oligocene sediments rest unconform- ably on lower and middle Eocene, respectively. In Holes 540 and 538A, a remarkable, almost complete Oligocene sequence occurs beneath Zone P22. In these two holes, planktonic foraminiferal Zones P21 to P18 (top part), spanning the entire upper and most of the lower Oligocene, were encountered. The oldest Oligocene and the Eocene/Oligocene boundary are missing in both holes.

The planktonic foraminiferal assemblages, mainly from nannofossil-foraminiferal chalk, are rich and diversified throughout. Because of the occurrence of the index species, zonal boundaries were easily identified in both Hole 538A and Hole 540. Faunas change very gradually, except for two major breaks in the smaller components, which coincide with the abrupt extinction of Chiloguembelina spp. and Tenuitella spp. at the $\mathrm{P} 21 \mathrm{~b} / \mathrm{P} 22$ boundary and of Pseudohastigerina spp. at the P20/ P19 zonal boundary. Chiloguembelinids, dominant in Zone P21b, suddenly disappear, and are replaced by small globigerinids in P22, whereas pseudohastigerinids, abundant in P19, are replaced by chiloguembelinids of increasing abundance and, in minor amount, by Cassigerinella chipolensis and tenuitellids.

Although rich, the planktonic faunas are not well preserved throughout. Planktonic foraminifers in some intervals are dissolved to different degrees. This can be seen in the intervals $538 \mathrm{~A}-7-3,40 \mathrm{~cm}$ to $538 \mathrm{~A}-8-3,42 \mathrm{~cm}$ (upper Oligocene, Zone P21b) and 538A-14-1, 51-54 cm (lower Oligocene, Zone P18). Moreover, abundance and size of some taxa, such as Globorotalia opima opima and globoquadrinids, may vary from layer to layer several times within the same zone. Such variations are suggested to be the results of climatic fluctuations to which the area was subjected during most of the Oligocene. Preliminary quantitative analyses of the Oligocene faunas from Hole 538A suggest a positive correlation between the occurrence of cooler-water assemblages and lower weight percentage of the residue $>45 \mu \mathrm{m}$ and/or dissolution stages.

As mentioned in the site chapter for Site 538, the rate of sediment accumulation in Hole 538A during the Oligocene fluctuated from 1 to 5 Bubnoff in the lower portion of the sequence (Zone P20 to Zone P18 partim) to $36 \mathrm{~B}$ in Zone P22, with intermediate values of 9B and 19 B in Zones P21b and P21a, respectively. The lowest rates coincide with dissolution events and possibly with cooling episodes.

A biostratigraphic succession like that in Hole 538A was recovered in Hole 540, where, however, Oligocene sediments were deposited at a very different rate of accumulation, for a total thickness of over $170 \mathrm{~m}$, as compared with the $123 \mathrm{~m}$ of Hole 538A. Such differences are as follows:

\begin{tabular}{lcc}
\hline \multirow{2}{*}{$\begin{array}{c}\text { Planktonic } \\
\text { foraminiferal } \\
\text { zones }\end{array}$} & \multicolumn{2}{c}{ Accumulation rate (B) } \\
\cline { 2 - 3 } & Hole 538A & Hole 540 \\
\hline P22 & 36 & 55 \\
P21b & 9 & 18 \\
P21a & 19 & 9 \\
P20 & 5 & 9 \\
P19/P18 & 1 & 8 \\
partim & & \\
\hline
\end{tabular}


Highest rates at Site 540 are partially related to the occurrence of discrete slumpings of apparently penecontemporaneous material (see photograph of Core 14, site chapter, Sites 535,539 , and 540 , this volume) and of resedimented shallow-water debris with ash layers scattered throughout.

\section{Eocene and Paleocene}

The base of the Oligocene (base of Zone P18) and the Oligocene/Eocene boundary are missing both in Hole $538 \mathrm{~A}$ and in Hole 540, but the hiatus is very short in Hole 540, where a 4-cm ash layer overlies the interval between $540-25-1,110 \mathrm{~cm}$ and $540-27-1,150 \mathrm{~cm}$, which contains planktonic faunas of the uppermost Eocene Zone P16. Below Sample 540-25,CC, which contains Turborotalia cunialensis, planktonic foraminifers are poorly preserved, and assignment of the remainder of the interval is based on nannofossil data. A larger gap is recorded in Hole 538A, where the entire Zone P16 is missing and the youngest Eocene sediments recovered belong to the middle lower Zone P15.

The remaining Eocene through Paleocene of all sites, like the Neogene, is interrupted by frequent hiatuses of variable duration. We now summarize the planktonic foraminiferal zones recorded and identified, proceeding from young to old.

Zones P14 and P13, upper middle Eocene. Hole 538A: interval from Core 538A-15 to 538A-17-5, $76 \mathrm{~cm}$. This interval yielded moderately well-preserved planktonic faunas rich in diagnostic species. These two zones are in normal succession with the overlying upper Eocene Zone P15.

Zones P12, mid-middle Eocene. Hole 540: interval from 540-27-2 to 540-28,CC. Planktonic faunas are rich but poorly preserved. Common species are Globigerinatheka index, G. tropicalis, Morozovella spinulosa, Acarinina spinuloinflata, and Turborotalia boweri (common). This age is in agreement with that inferred from calcareous nannofossils.

Zone P10, lower middle Eocene. Hole 540: Core 540-29 (partim). Hole 537: Core 537-2 and washed interval 537-H2-1, 0-40 cm. Hole 538A: interval from 538A-17, CC to 538A-20-2, $76 \mathrm{~cm}$. Radiolarians are dominant in the washed residues from all three holes where this interval or part of it was recovered. Planktonic foraminifers are few to rare, very poorly preserved, and severely dissolved. Zonal assignment is inferred mainly from nannofossil data. The most complete record seems to occur in Hole 537 (see Watkins and Bowdler, this volume).

Zone P9, upper lower Eocene. Nannofossils indicate that this zone may be present in stratigraphic continuity with the overlying Zone P10 in Hole 540, Core 29 and in Hole 537 in the lower part of the washed Core $\mathrm{H} 2$, but planktonic foraminiferal faunas are too poor for reliable zonal identification. Unquestionable planktonic assemblages of Zone P9 were identified only in Hole 536 in the $2 \mathrm{~cm}$ of foraminiferal limestone coating a hardground at the very top of core 536-9. Radiolarians are abundant.

Zone P8, mid-lower Eocene. Hole 538A: interval 538A-21-1, 32-59 cm. A rich, well-preserved planktonic foraminiferal fauna belongs to the lower part of this zone. Associated with it are frequent upper Paleocene forms, either reworked or admixed mechanically during drilling operations. The upper part of Zone P8 may be represented in a core-catcher sample of washed Core $\mathrm{H} 2$ from Hole 537.

Zone P6, Morozovella subbotinae Subzone, lower Eocene. Hole 537: 537-3-1, 0-41 cm. Abundant and wellpreserved planktonic foraminifers indicate the upper part of the subzone.

Zone P4, upper Paleocene. Hole 540: interval from $540-30-1$ to $540-30, \mathrm{CC}$, and possibly in 540-31-1, 0-46 $\mathrm{cm}$. Hole 536: interval from 536-9-1, $2 \mathrm{~cm}$ to $536-9-3,17$ $\mathrm{cm}$. Hole 537: interval from 537-3-1, $41 \mathrm{~cm}$ to $537-3-2$, $43 \mathrm{~cm}$. Hole 538A: at 538A-21-1, $59 \mathrm{~cm}$ and from $538 \mathrm{~A}-20-2,77 \mathrm{~cm}$ to $538 \mathrm{~A}-20-4,100 \mathrm{~cm}$. In all four holes planktonic foraminifers are abundant, diversified, and well preserved. The upper limit of this zone coincides with an abrupt change in lithology or a hardground in all occurrences except in Hole 540. In Hole $538 \mathrm{~A}$, P4 zonal assemblages occur twice in the cored sequence, once within a manganese crust of the hardground at $59 \mathrm{~cm}$ in Section 538A-21-1, which is enclosed by lower Eocene sediments (above) and lower Maestrichtian (below), and again in the interval from 538A$20-2,77 \mathrm{~cm}$ to $538 \mathrm{~A}-20-4,100 \mathrm{~cm}$, which is part of a 7.5-m slumped interval within upper lower and lower Eocene sediments. The upper surface of the slump at $538 \mathrm{~A}-20-2,77 \mathrm{~cm}$ is marked by a prominent hardground.

In Hole 536 the upper limit of Zone P4 is coincident with the manganese crust of a hardground in Section 536-9-1 at $2 \mathrm{~cm}$. Planktonic foraminifers are abundant and well preserved. Common are the index species Planorotalites pseudomenardii, Morozovella velascoensis, M. pusilla, M. laevigata, Acarinina mckannai, and Zeouvigerina sp. Manganese nodules occur throughout the interval of the zone. A distinct lithic change marks the top of this zone in Hole 537 at 537-3-1, $41 \mathrm{~cm}$. As in Hole 536, planktonic foraminifers are abundant and well preserved throughout. In Section 537-3-2, the P4 zonal species are associated with reworked upper and lower Cretaceous planktonic and benthic foraminifers. Barren volcaniclastic sediments underlie the nannofossil-foraminiferal chalk of Zone P4. In Hole 540 the youngest planktonic foraminifers attributable to Zone P4 occur in nannofossil-foraminiferal chalk and the pebbly chalk recovered in Core 540-30, but they are absent at some levels, such as the interval $540-30-1,96-99 \mathrm{~cm}$. In other levels planktonic foraminiferal assemblages include forms of widely varying age. In 540-30, CC the youngest faunal elements belong to the upper Paleocene Zone P4, but the assemblage is dominated by forms of the lower Paleocene Zone P2 (Morozovella uncinata Zone), and a few upper Cretaceous globotruncanids are also present.

\section{Lower Paleocene and the Cretaceous/Paleogene Boundary}

Lower Paleocene sediments were recovered in Holes 536 and 538A. In Hole 538A almost three meters of orange-pink chalk, belonging to the lower part of the slump mentioned in the previous zone (538A-20-4, 111 
$\mathrm{cm}$ to $538 \mathrm{~A}-21-1,32 \mathrm{~cm}$ ), yielded an abundant, diversified, well-preserved planktonic foraminiferal fauna attributable to Zone P1c ("Subbotina" pseudobulloides Subzone) and possibly extending into the base of P1d ("Morozovella" trinidadensis Subzone). Common are the index species, "Morozovella" inconstans, Subbotina triloculinoides, Globoconusa daubjergensis, and chiloguembelinids. The evolutionary stage of the morozovellids suggests that the assemblage is close to the P1d/P1c boundary, but true "Morozovella" trinidadensis seems to be absent.

A more nearly complete sequence was recovered in Hole 536, where the lower part of the interval from $536-9-3,18 \mathrm{~cm}$ to $536-9, \mathrm{CC}$ contains a record across the Paleocene/Maestrichtian boundary, from the top of Zone P1 (M. trinidadensis Subzone) to the uppermost Maestrichtian Abathomphalus mayaroensis Zone, and includes the "Globigerina" eugubina Zone. Lower Paleocene planktonic foraminiferal faunas in the orange-pink chalk are rich and diversified. Zonal assemblages were recognized in the following intervals: $536-9-3,18 \mathrm{~cm}$ to 9-4, $80 \mathrm{~cm}-$ Morozovella trinidadensis Subzone (P1d); $536-9-4,81 \mathrm{~cm}$ to $9-5,40 \mathrm{~cm}-$ Subbotina pseudobulloides Subzone (P1c-a); 536-9-5, $41 \mathrm{~cm}$ to 9-5, $69 \mathrm{~cm}-$ "Globigerina" eugubina Zone; 536-9-5, $70 \mathrm{~cm}$ to 536 9,CC-Abathomphalus mayaroensis Zone.

The Maestrichtian/Paleocene boundary was placed at $70 \mathrm{~cm}$ in Section 536-9-5. No lithic change occurs at that level. But upper Cretaceous forms occur as high as 536-9-5, $57 \mathrm{~cm}$, and the lowermost Paleocene "Globigerina" eugubina fauna infills burrows for more than $10 \mathrm{~cm}$ below the boundary.

Preservation of planktonic foraminifers is moderately good from 536-9-3 down to 536-9-5, $30 \mathrm{~cm}$, where it be- gins to worsen progressively. The G. eugubina assemblage, particularly in the burrows, consists of heavily recrystallized forms, often encrusted with small abundant dolomite crystals. Below the Maestrichtian/Paleocene boundary, in the upper Maestrichtian sediments, foraminiferal preservation worsens rapidly with the change in lithology from chalk to a coarse foraminiferal, turbiditic, volcanogenic siltstone. In Sample 536-9,CC most of the foraminiferal tests are highly dissolved, consequently fragile, and infilled with altered volcanic glass (see Fig. 4).

Upper Maestrichtian assemblages lack several diagnostic species, including Abathomphalus mayaroensis. The assignment to this zone is supported, however, by the occurrence of the planktonic foraminifers Racemiguembelina fructicosa, Globotruncana contusa, and Pseudoguembelina excolata and by the nannofossil Micula prinsii in Sample 536-9,CC.

The interval from $536-9-5,70 \mathrm{~cm}$ to $536-9, \mathrm{CC}$ contains the only record of upper Maestrichtian sediments from all drill sites of Leg 77.

\section{Cretaceous}

Cretaceous sediments were recovered from all five single-bit holes that penetrated pre-Neogene layers (see Table 1 and Figs. 5-6). Two drill holes, at the basin Sites 535 and 540, are located $30 \mathrm{~km}$ apart on the side of an erosional valley on the flank of the Florida Escarpment. They were chosen to drill as much of the Mesozoic sequence below the so-called mid-Cretaceous unconformity $(\mathrm{MCU})$ as a single bit would allow. Drilling at Site 540 , the shallower site, began above and penetrated the MCU, whereas drilling at Site 535, located downslope, began beneath and penetrated deeper below the MCU

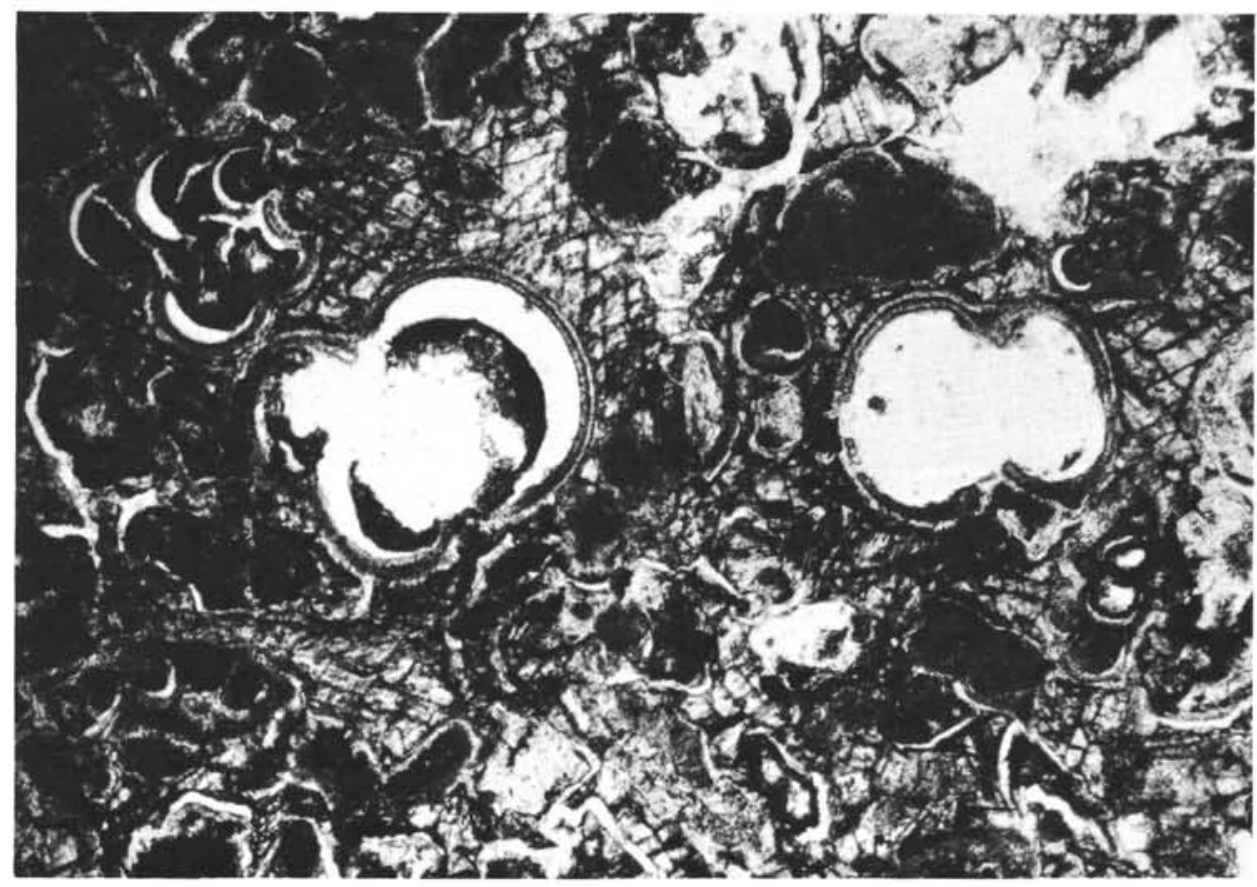

Figure 4. Microfacies with volcanic glass and Heterohelicidae, Maestrichtian. Sample 536-9,CC (3-6 $\mathrm{cm})$; magnified $\times 75$, 
Table 1. Operational data for Leg 77 holes.

\begin{tabular}{|c|c|c|c|c|c|}
\hline Hole & $\begin{array}{l}\text { Latitude } \\
\text { (all N) }\end{array}$ & $\begin{array}{l}\text { Longitude } \\
\text { (all W) }\end{array}$ & $\begin{array}{c}\text { Water } \\
\text { depth } \\
\text { (m) }\end{array}$ & $\begin{array}{c}\text { Total } \\
\text { drilled } \\
\text { depth } \\
\text { (m) }\end{array}$ & $\begin{array}{l}\text { Total } \\
\text { recovery }\end{array}$ \\
\hline \multicolumn{6}{|c|}{ Basin holes } \\
\hline 535 & $23^{\circ} 42.48^{\prime}$ & $84^{\circ} 30.97^{\prime}$ & 3450 & 714.0 & 505.07 \\
\hline 539 & $23^{\circ} 47.34^{\prime}$ & $84^{\circ} 25.19^{\prime}$ & 3089 & 7.0 & 4.40 \\
\hline $539 A$ & $23^{\circ} 47.20^{\prime}$ & $84^{\circ} 25.19^{\prime}$ & 3076 & 7.5 & 7.23 \\
\hline 540 & $23^{\circ} 49.73^{\prime}$ & $84^{\circ} 22.25^{\prime}$ & 2926 & 745.4 & 335.75 \\
\hline \multicolumn{6}{|c|}{ Basement holes } \\
\hline 536 & $23^{\circ} 29.39^{\prime}$ & $85^{\circ} 12.58^{\prime}$ & 2790 & 213.0 & 65.73 \\
\hline 537 & $23^{\circ} 56.01^{\prime}$ & $85^{\circ} 27.62^{\prime}$ & 3123 & 225.0 & 15.87 \\
\hline 538 & $23^{\circ} 50.98^{\prime}$ & $85^{\circ} 10.26^{\prime}$ & 2820 & 6.0 & 5.15 \\
\hline $538 \mathrm{~A}$ & $23^{\circ} 50.95^{\prime}$ & $85^{\circ} 09.93^{\prime}$ & 2742 & 332.5 & 137.67 \\
\hline
\end{tabular}

(see site chapters, this volume). Three other holes, 536, 537 , and 538A, at the basement sites, were located on high-standing fault blocks, and are characterized by a thin sedimentary cover on basement (Scientific Party of Leg 77, in press). They were drilled to reconstruct the tectonic history of this part of the Gulf of Mexico.

The oldest dated sediments are lowermost Cretaceous (Berriasian), and were recovered from Holes 535, 537, and 538A. A dolomitic unit recovered from Hole 537 appears to be older than Cretaceous, but the lack of diagnostic fossils prevented determination of how much older it is.

Characteristic of all drilled sequences is the rarity of post-Cenomanian Cretaceous sediments. The dominant lithotype is nannofossil-foraminiferal chalk (Holes 536 and $538 \mathrm{~A}$ ), but calcareous-volcanic sandstones (lower Maestrichtian) were recovered from Hole 540.

The Cenomanian to lowermost Cretaceous interval is better represented at some of the sites. No recovered sequence is complete, however, at any of the drill sites.

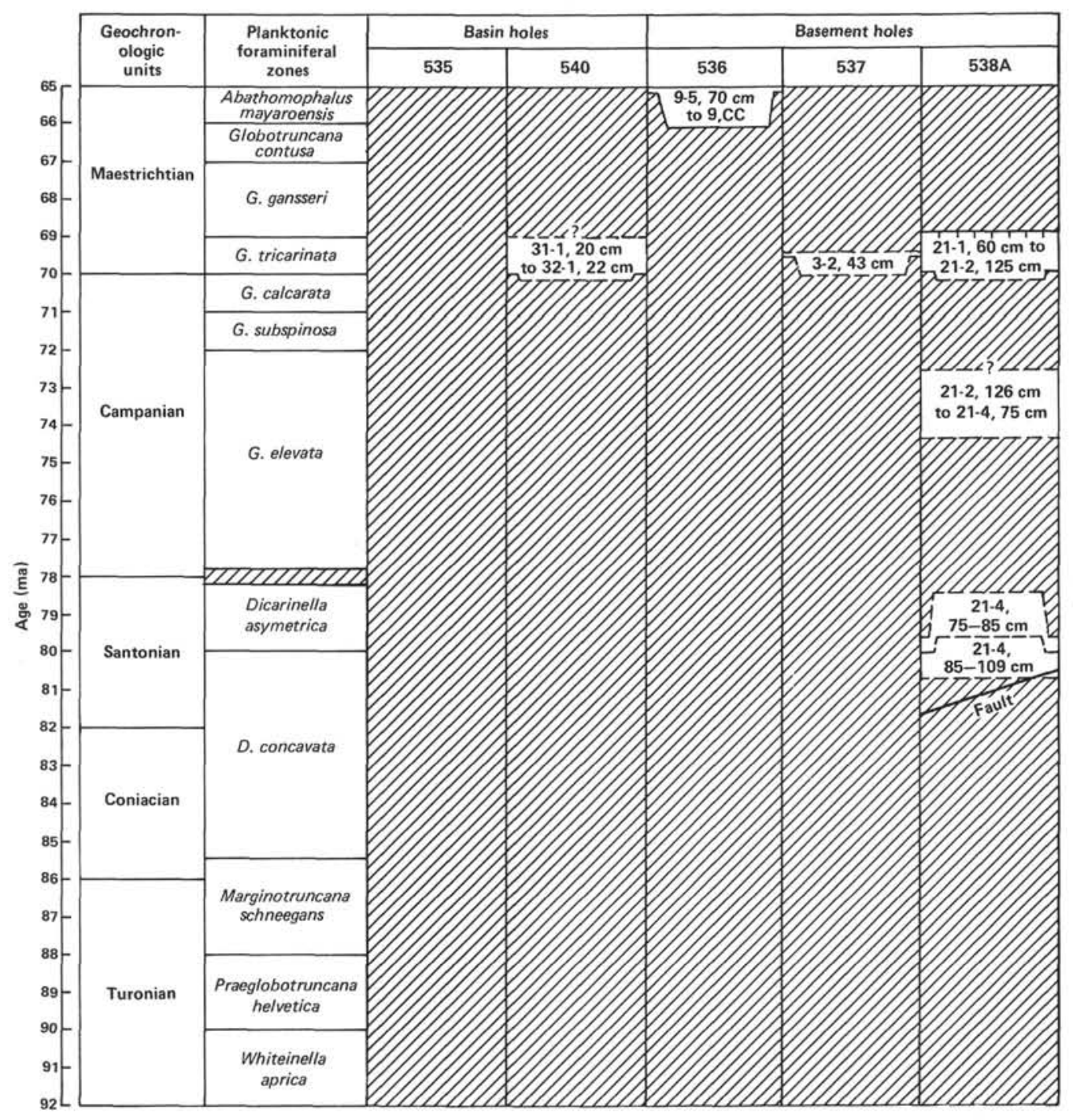

Figure 5. Age, geochronology, and foraminiferal zonation of Turonian-Maestrichtian sediments cored during Leg 77. Diagonal pattern $=$ hiatus; $\Pi \Pi T=$ hardground. 


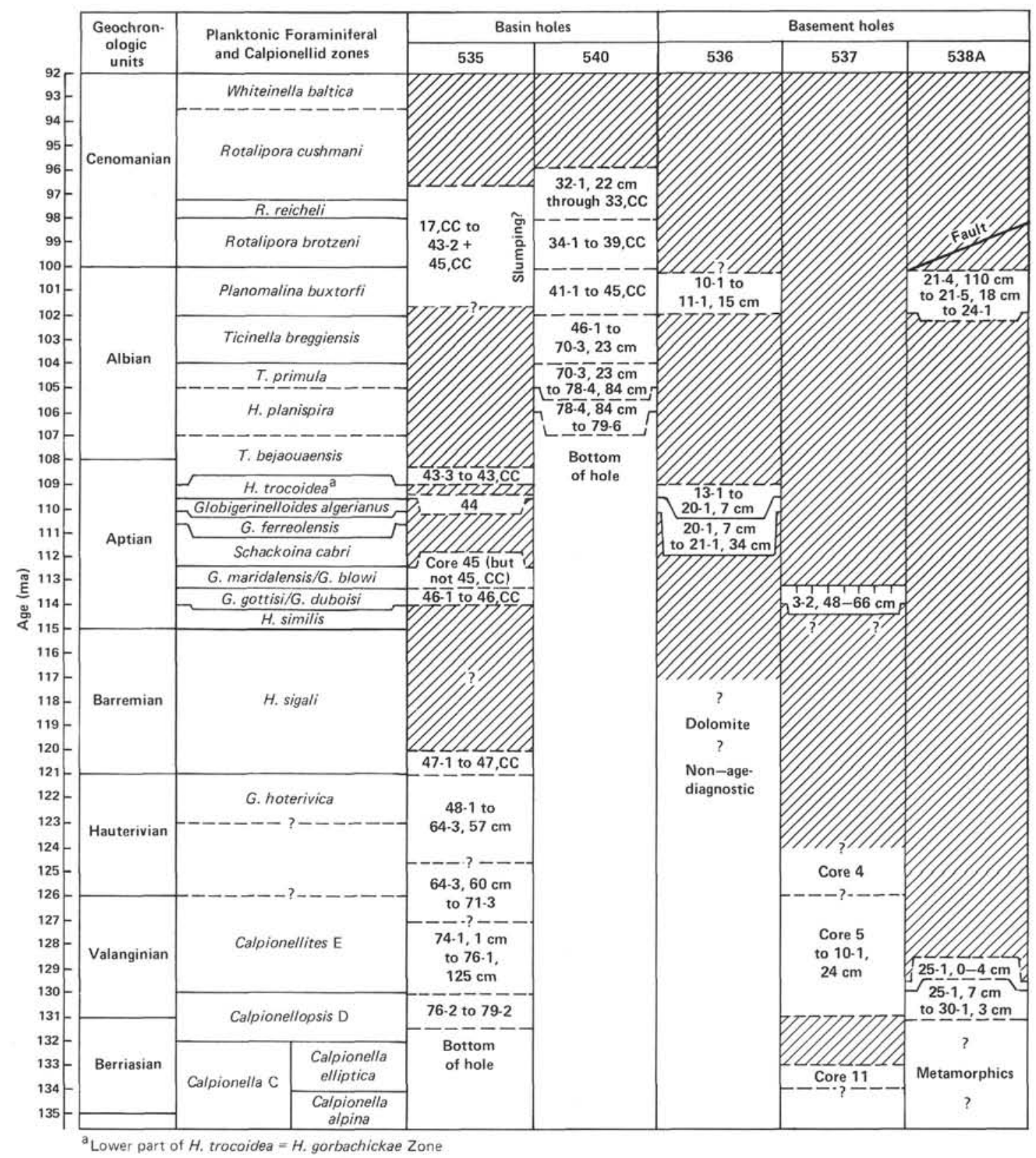

Figure 6. Age, geochronology, and foraminiferal and calpionellid zonations of Berriasian-Cenomanian sediments cored during Leg 77. Diagonal pattern $=$ hiatus; $\Pi \Pi T=$ hardground.

Several hiatuses, often many millions of years in duration, were identified at all of them (Figs. 5 and 6). As mentioned in the Introduction, sediments of this interval consist largely of laminated and bioclastic limestones, of which the latter are very coarse in texture (breccia). Autochthonous pelagic chalk and/or limestone are very limited spatially and temporally. Planktonic organisms (e.g., foraminifers, radiolarians, calpionellids) recovered from this interval are in the main poorly to very poorly preserved, very irregularly distributed, oriented, and sizesorted, and frequently reworked. Moreover, laminated and bioclastic limestones contain large amounts of displaced, often reworked, shallow-water debris, which mask and dilute the autochthonous pelagic and bathyal faunas (see Sliter and Premoli Silva, this volume).
To decipher the complex, contradictory faunal data, complicated by very poor recovery from some holes, over one thousand samples were processed. Some of them were barren and are omitted from Figures 7-11.

When possible, the biostratigraphic study was conducted on washed samples, but more frequently from thin sections cut, for some holes, from every single piece of indurated limestone (see Hole 538A). Distribution charts (see Fig. 7-11), constructed per single hole for the Cretaceous interval, include information on (1) occurrence and abundance of planktonic foraminifers and calpionellids, (2) their reworking, (3) occurrence and abundance of autochthonous bathyal benthic foraminifers, (4) occurrence and abundance of displaced and/or reworked shallow-water large and small benthic foramini- 
fers, (5) occurrence and abundance of remains of other mega- and microfossils, and (6) occurrence and abundance of inorganic components. In addition, detailed description of displaced and/or reworked neritic material is included in Figures 2 to 9 of the chapter by Sliter and Premoli Silva (this volume).

\section{Basin Sites 535 and $\mathbf{5 4 0}$}

\section{Site 540}

At Site 540, the shallowest of the Florida transect, several planktonic foraminiferal zones could be identified, in spite of the extremely complex succession of turbiditic Upper Cretaceous sediments, the presence of hardgrounds in the Lower Cretaceous portion, and the poor core recovery (see Fig. 7). We summarize them here, proceeding from young to old.

Globotruncana tricarinata Zone, lower Maestrichtian. The interval from $540-31-1,1 \mathrm{~cm}$ to $540-32-1,22 \mathrm{~cm}$ consists of laminated, often graded, calcareous-volcanic sandstone. Planktonic foraminiferal faunas may be abundant in some layers (Sample 540-31-1, 20-21 cm), scarce or absent in others. In spite of poor preservation, several critical species could be identified: G. arca, G. stuarti, G. stuartiformis, G. subspinosa, and Globotruncanella havanensis, among others, which indicate the lower Maestrichtian Globotruncana tricarinata zonal assemblage. Two specimens, however, one planktonic (Racemiguembelina fructicosa [Sample 540-31-1, 20-21 cm]) and one a large shallow-water benthic specimen (Lepidorbitoides $\mathrm{cf}$. socialis [Sample 540-31-2, 34-35 cm]), would suggest that this interval is in fact upper Maestrichtian (on the basis of the range of the two mentioned species) or younger, and that the lower Maestrichtian $G$. tricarinata zonal species are reworked, as are the lower Cretaceous planktonic species (Praeglobotruncana stephani) and the shallow-water forms (orbitolinids) recorded from some coarser layers (540-31-2, 137-144 cm).

From 540-32-1, $23 \mathrm{~cm}$ to the bottom of Hole 540, an apparently continuous succession was recovered at Site 540 , spanning the interval from middle Cenomanian to middle Albian. The identified zones follow.

Rotalipora cushmani Zone, R. appenninica Subzone, middle Cenomanian. Interval from $540-32-1,22 \mathrm{~cm}$ through 540-33,CC. Pebbly limestone and chalk and bioclastic limestone are the dominant sediments in this interval. In spite of their chaotic character, some finegrained layers yielded poorly preserved planktonic faunules characterized by rare specimens of $R$. greenhornensis, T. appenninica, $R$. brotzeni, $P$. stephani, and $P$. aumalensis, which indicate the $R$. cushmani Zone, $R$. appeninica Subzone, even in the absence of the nominal species. Pebbles of bioclastic limestone and of more common whitish chalk, imbedded in the finer matrix, yielded shallow-water debris and Albian planktonic foraminifers.

Rotalipora brotzeni Zone, lower Cenomanian. Interval from 540-34-1 to 540-39, CC, and possible Core 540-40. Pebbly limestone and bioclastic limestone continue into the upper part of the interval, but in Cores 540-37 to 540-39, sediments become finer and laminated.
Planktonic foraminifers are poorly preserved and rare. Zonal attribution is based mainly on negative evidence, such as the absence of younger rotaliporids and older Planomalina buxtorfi. Pebbles of bioclastic limestone yield shallow-water debris, including cuneolinids and orbitolinids, similar to and of the same age as that mentioned in the previous zone.

Planomalina buxtorfi Zone, uppermost Albian (Vraconian). Interval from 540-41-1 to 540-45,CC. Sediments in this interval are represented by laminated and/or mottled limestone with a few thin interbeds of dark marly limestone. Most of the limestones could not be disaggregated, and were studied in thin section. Washed material obtained from the softer dark beds yielded wellpreserved, although somewhat narrow, planktonic faunas characteristic of the Planomalina buxtorfi Zone. Besides the index species, Rotalipora appenninica, $R$. balernaensis, Praeglobotruncana delrioensis, Hedbergella lybica, $H$. delrioensis, $H$. planispira, and Globigerinelloides bentonensis are common. Heterohelix moremani occurs in the upper part of the zone, and the last representatives of Ticinella primula, T. raynaudi, Rotalipora ticinensis, and rare $R$. praebalernaensis are confined to the lower levels of this zone. Poorly preserved and recrystallized radiolarians are frequent throughout the interval. Calcisphaerulids are concentrated in thin bands made only by them (Sample 540-43-1, 137-138 cm) or are sparse in the matrix. Displaced, reworked shallow-water debris occurs in coarser layers $(540-45, C C)$ associated with reworked upper Aptian foraminifers and Favusella washitensis, which was not found in the finer pelagic layers.

Ticinella breggiensis Zone, upper Albian. Interval from $540-46-1$ to $540-70-3,23 \mathrm{~cm}$. As above, the dominant lithotypes in this interval are laminated limestones with rare soft, dark layers. Planktonic foraminifers become more poorly preserved and less abundant with increasing depth. Critical species, such as the nominal species and Ticinella raynaudi, are rare and irregularly distributed from layer to layer. The lower boundary of the zone was placed at the lowermost apparent occurrence of both taxa $(540-70-3,23 \mathrm{~cm})$. Several layers, which alternate with those containing the autochthonous faunas, yielded planktonic foraminifers from older Albian zones. Benthic foraminifers and other debris of shallow waters occur in coarser layers, always accompanied by Favusella washitensis. Radiolarians, frequently pyritized, were common in some samples.

Ticinella primula/Hedbergella rischi Zone, lower upper to middle Albian. Interval from $540-70-3,23 \mathrm{~cm}$ to $540-78-4,84 \mathrm{~cm}$. Planktonic foraminiferal faunules contain only Ticinella primula, Hedbergella rischi, and $H$. planispira, and were assigned to the $T$. primula/H. rischi Zone in absence of younger taxa. Radiolarians are still common in some layers, particularly in the upper part of the interval. In Core 540-77 and downward to the bottom of the zone, coarser skeletal layers containing large amounts of shallow-water debris and large, well-developed $F$. washitensis increase gradually down the section, replacing the progressively less frequent pelagic layers. 


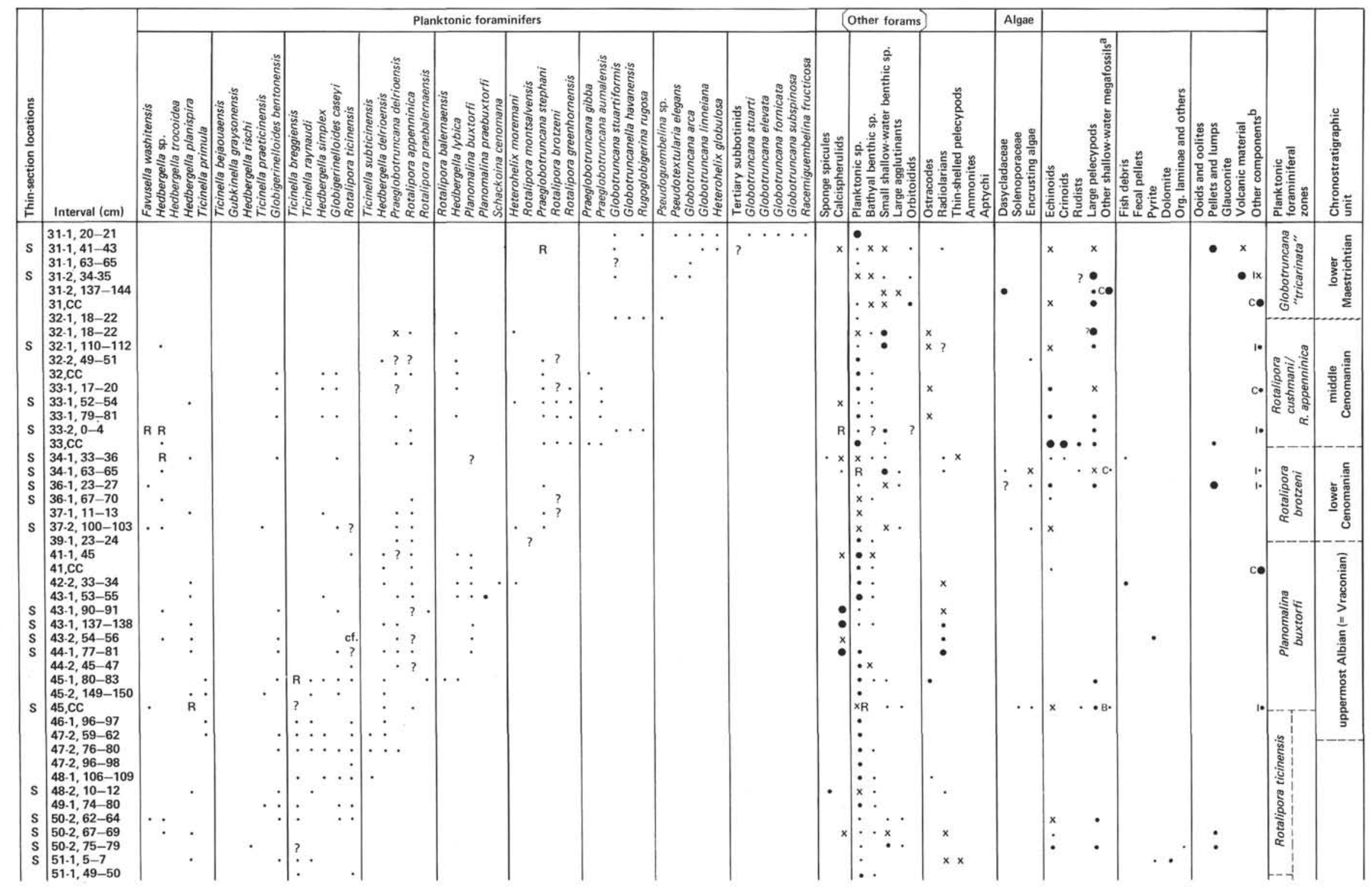




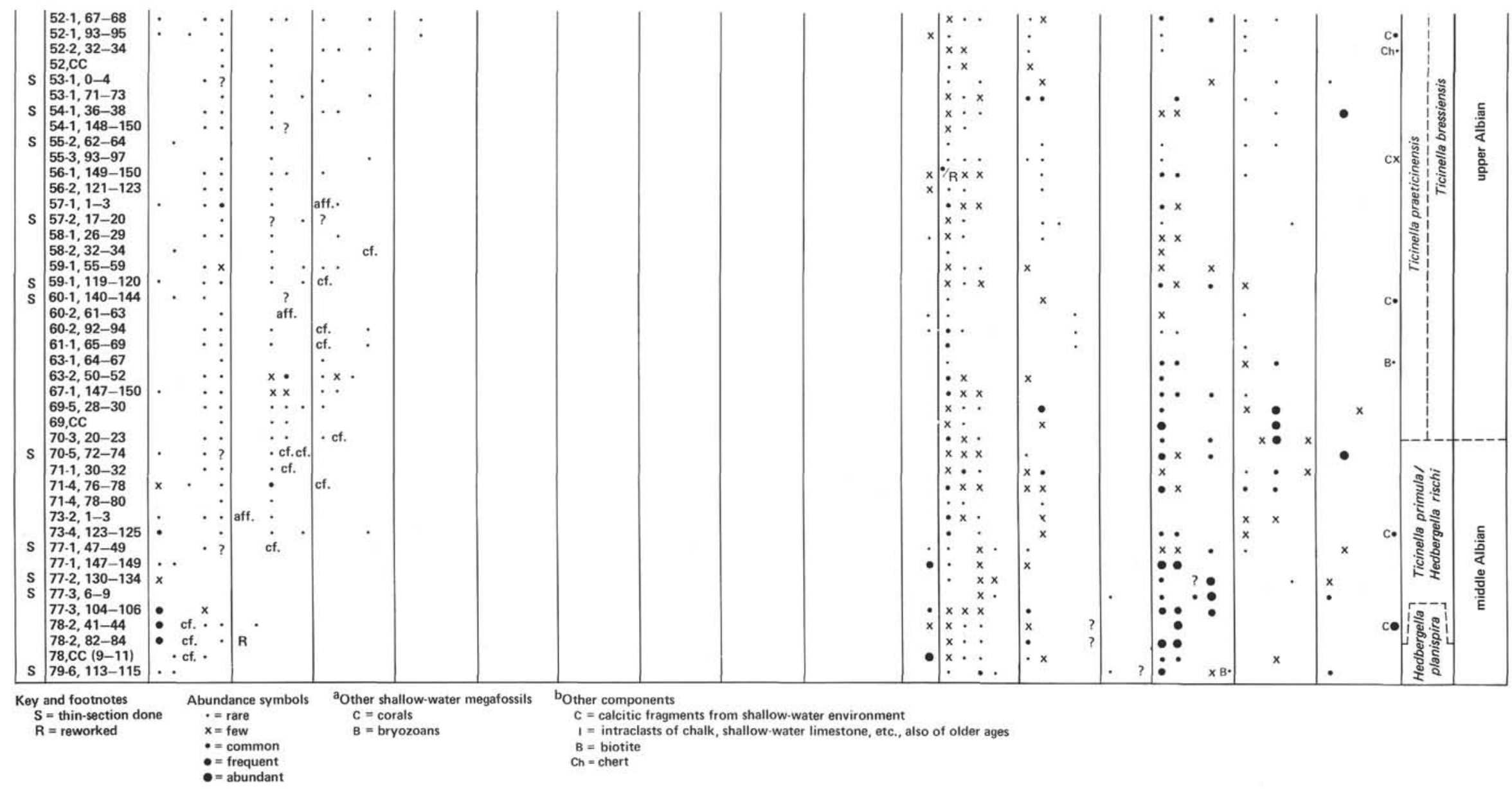

Figure 7. Distribution of Cretaceous planktonic foraminifers and associated organisms from Hole 540, Leg 77. 
Hedbergella planispira Zone, lower middle to lower? Albian. Interval from 540-78-4, $84 \mathrm{~cm}$ to 540-79-6 (bottom of hole). Planktonic foraminifers found in this interval belong to only two species, Hedbergella planispi$r a$ and Favusella washitensis, which latter taxon first evolved in the early Albian. This very poor assemblage is tentatively attributed to the $H$. planispira Zone, but it may belong to the $T$. primula/H. rischi Zone. Redeposited shallow-water materials become prominent in this lowermost portion of Hole 540.

\section{Site 535}

As mentioned, Site 535 was drilled downslope with respect to the shallowest Site 540, beneath the MCU, in the hope of reaching the Jurassic. Because of bit failure, however, Hole 535 was ended in sediments of the lowermost Cretaceous (upper Berriasian).

At Site 535 the Cretaceous succession is extremely complex, both sedimentologically and biostratigraphically. In particular, the interval from 535-17,CC through Section $535-43-2(240 \mathrm{~m})$ is dominantly limestone with abundant shallow-water components, whereas the interval from Section 535-43-3 to total depth of the hole $(714.0 \mathrm{~m})$ consists largely of laminated limestones that contain several layers of apparently pure to slightly argillaceous pelagic limestone. Some layers of the latter are limited by indurated surfaces, interpreted as possible hardgrounds. Black, organic, and pyrite-rich marly layers interbedded within this lower interval suggest in situ deposition. But they yielded a mixture of benthic fossils from different environments (see Sliter and Premoli Silva, this volume).

\section{Interval from 535-17, CC through 535-43-2}

In spite of the large number of samples investigated both in thin section and as washed residues, this upper interval could not be zoned on the basis of planktonic foraminifers, as shown in Figure 8A. Planktonic foraminifers, particularly those from laminated limestones, are rare here, and comprise mainly small species. Larger foraminifers occur infrequently as fragments at the base of coarser, laminated layers with abundant shallow-water debris.

Richer and better preserved planktonic faunas were recovered from some of the more clayey layers from Section 535-31-6 to Core 535-42. The largest population, recovered from Sample 535-32-3, 110-112 cm, is attributable to the middle Albian Ticinella primula/Hedbergella rischi Zone, on the basis of occurrence of the nominal species, Ticinella subbreggiensis, Hedbergella cf. infracretacea, and Favusella washitensis. In Cores 535-36 to 535-39, rare Hedbergella planispira and, again, Favusella washitensis were found. On the basis of this poor material, the interval is correlative with the lower Albian Hedbergella planispira Zone. From Core 535-40 to Section 535-43-3, scattered Ticinella bejaouaensis, associated with a few hedbergellids, indicate the upper part of the Ticinella bejaouaensis Zone (lower Albian).

The foraminiferal zonal succession is normal for the middle to lower Albian, and is similar to the nannofossil data, but the number of samples is small. Moreover, the dates given by the foraminifers are contradicted by ammonite occurrences (see Young, this volume), which include juvenile specimens of Acompsoceras in Cores 535-31 and 535-33, that indicate middle Cenomanian at the oldest. A single fragment of rotaliporid (Rotalipora greenhornensis?) from Sample 535-22-5, 134-136 cm is therefore worth mention as an indication of a late Cenomanian date for the upper part of the interval. Consequently, the middle and lower Albian planktonic assemblages may be reworked, although in such a way as to retain their zonal sequence.

A juvenile specimen of the ammonite Scaphites, recovered from 535-45, CC (see discussion of zonation for Core 535-45), also affects the interpretation of the interval from 535-17, CC to 535-43-2. It could have fallen from uphole to become incorporated in 535-45, CC, for drilling was uneven and core recovery very poor in the new lithofacies that began at Section 535-43-3. If so, it allows no older than an earliest Albian assignment for the oldest (basal?) part of the interval from 535-17,CC to 535-43-2. Ammonitic remains are more common, however, in the recoveries of Cores 535-42 to 535-46 (see core descriptions, Site 535, this volume), so the specimen may be in place. If so, it still contradicts the age of the planktonic foraminifers in Sample 535-45, CC and is another suggestion of reworking at Site 535 .

Finally, a residue from Sample 535-42-5, 130-135 cm contains small, poorly preserved Upper Cretaceous foraminifers, including Heterohelix globulosa, H. planata, $H$. sp., Rugoglobigerina rugosa, Pseudoguembelina sp., Globotruncana gagnebini?, Pseudovigerina seligi?, "Bolivinopsis rosula," Nonionella cretacea, Gavelinella ssp., and other benthic species, mixed with Hedbergella cf. infracretacea, $H$. planispira?, and ?Ticinella bejaouaensis. There were no Upper Cretaceous nannofossils in nearby samples, and it seems almost certain that the residue was contaminated in the laboratory; but it is mentioned because of the incongruities of this hole.

To recapitulate, the interval from $535-17, \mathrm{CC}$ to 535 43-2 is made up of laminated limestones containing much fine biogenic calcite but infrequent and few, apparently autochthonous, foraminiferal specimens, and these are suspect. Although a deep-water deposit, the lithofacies is not a typical pelagic ooze or chalk, and the entire interval may well be a reworked canyon fill and/or slump complex.

At Section 535-43-3 the lithofacies changes to seemingly autochthonous, more basinal limestones and marls, which continue with frequent, variably dark and organic, pyritic marls to total depth of the hole at Core 535-79. This succession was divided into three parts on the basis of general faunal aspect. The intervals are (1) $535-43-3$ to $535-47, \mathrm{CC}$; (2) $535-48-1,1 \mathrm{~cm}$ to $535-64-3$, $57 \mathrm{~cm}$; and (3) 535-64-3, $60 \mathrm{~cm}$ to $535-79$ (bottom of hole). We now discuss these in detail.

\section{Interval from 535-43-3 to 535-47, CC}

The sediments in this interval consist mainly of indurated, frequently laminated, limestones with rare softer, dark interbeds (see Fig. 8B). The indurated limestone, mainly whitish, is rich in planktonic foraminifers, am- 
monite protoconchs, and pelagic pelecypods, and the darker interbeds contain only rare autochthonous bathyal benthic foraminifers.

On the basis of the planktonic foraminifers, mainly identified in thin section, five biozones were recognized (summarized here from young to old).

Ticinella bejaouaensis Zone, uppermost Aptian-lowermost? Albian. Interval from 535-43-3 to 535-43,CC. Planktonic assemblages, moderately well preserved, contain the index species, Ticinella roberti, Planomalina $\mathrm{cf}$. cheniourensis, Hedbergella trochoidea, $H$. delrioensis, $H$. cf. similis associated with rare Favusella washitensis, and the calpionellid Colomiella mexicana. The absence of Globigerinelloides ferreolensis and the presence of Favusella washitensis and Colomiella recta suggest that this fauna is attributable to the middle part of the $T$. bejaouaensis Zone, which is close to the Aptian/Albian boundary.

Hedbergella gorbatchikae Zone, upper Aptian. Core 535-44. Planktonic assemblages, poorly to fairly well preserved, contain, besides the index species, Hedbergella trochoidea, $H$. infracretacea, $H$. similis, ferreolensis, G. aptiensis, G. barri, and Planomalina cf. cheniourensis.

Globigerinelloides maridalensis/Globigerinelloides blowi Zone, lower Aptian. Core 535-45 (excluding pebble in 535-45,CC). Planktonic species identified are the two nominal species, Globigerinelloides duboisi, Hedbergella infracretacea, $H$. similis, $H$. occulta, and Globuligerina hoterivica, an association that is characteristic of the zone. ${ }^{2}$

As mentioned, a pebble containing a small, juvenile specimen of Scaphites was recovered in 535-45,CC. It seems more likely to have caved from the basal part of the interval between 535-17, CC and 535-43-2 during the irregular drilling and poor recovery of the interval from 535-43-3 to 535-46, and therefore probably affects the age assignment of the former interval rather than that of the latter one. Ammonitic fossils are more common in the latter interval than in the former, however, and it is unclear where the base of the puzzling shallower section lies and what is the nature and continuity of the underlying one.

Globigerinelloides gottisi/Globigerinelloides duboisi Zone, lower Aptian. Core 535-46. Planktonic faunas are poorly preserved, and specimens are rare in most samples. The few species that were identified are Globigerinelloides gottisi, Hedbergella similis, $\mathrm{H}$. occulta, $\mathrm{H}$. sigali, and Globuligerina hoterivica, and these are characteristic of the Globigerinelloides gottisi/G. duboisi zonal assemblage.

Hedbergella sigali Zone, lower? Barremian. Core 535-47. Rare planktonic foraminifers were found in this interval. One specimen from Sample 535-47-2, 38-41 cm may be attributable to Hedbergella sigali, which ranges from the lower Barremian to the lower Aptian. On the basis of the occurrence of this taxon, Core 535-47 was dated as Barremian; but calcareous nannofossils suggest

\footnotetext{
${ }^{2}$ G. hoterivica is the new name for Caucasella hoterivica (see Appendix B).
}

lower Barremian at the youngest. A few other planktonic specimens of Globuligerina hoterivica and G. sp. 1 were also seen.

If age assignments are correct, the 43-m-thick interval from Section 535-43-3 to 535-47, CC represents an interval of about $20 \mathrm{Ma}$, from latest Aptian to early Barremian. The poor core recovery $(8.50 \mathrm{~m}=20 \%)$ prevented determination of whether the sequence is complete or interrupted by discrete hiatuses.

\section{Interval from $535-48-1,1 \mathrm{~cm}$ to $535-64-3,57 \mathrm{~cm}$}

In the sequence in this interval, rare globigerinids are the only planktonic foraminifers found in all the lithotypes (see Figs. 8B and 8C). All the foraminiferal taxa, including the rare small benthic species, are long-ranging and without biostratigraphic value; consequently, correlation of the sequence rests on the data for calcareous nannofossils. Radiolarians are much more abundant and persistent than the foraminifers, but are so poorly preserved, mainly recrystallized or pyritized, that they appear to be biostratigraphically useless.

According to nannofossil data, the sequence appears continuous, and represents the entire Hauterivian and possibly the upper Valanginian.

As mentioned, planktonic foraminifers are rare in this interval, but a single dark, softer layer from Sample $535-57-7,56-59 \mathrm{~cm}$ yielded a relatively rich assemblage of several species. In spite of their poor preservation as pyritized internal molds, Globuligerina hoterivica, $G$. cf. caucasica, Globuligerina sp. 1, Globuligerina sp. 2, and Hedbergella? sp. 1 could be identified (see Appendix B). Their generally accepted distribution (Grigelis and Gorbatchik, 1980) is consistent with an upper Hauterivian placement implied for this layer by its calcareous nannofossils (see Watkins and Bowdler, this volume).

\section{Interval from 535-64-3, $60 \mathrm{~cm}$ to 535-79 (Bottom of Hole)}

This lowermost part of the drilled sequence in Hole 535 is characterized by the occurrence of calpionellids, which provided age dating in addition to that provided by calcareous nannofossils (see Fig. 8C).

Calpionellids, first encountered at 535-64-3, $60 \mathrm{~cm}$, are most common in light-colored micritic limestones, which are more frequent in this interval than in the overlying ones. The interbedded dominant gray layers, mainly laminated, contain only poorly preserved radiolarians, frequently associated with minute dolomite crystals in some amount. Gray laminated layers become less frequent downward, whereas the whitish micritic limestones increase in total percentage. Dark, sometimes softer, layers are thicker and more frequent in this part of the sequence.

Calpionellids are sparse and rare down to Section 535-71-3, where their abundance increases considerably. They are common and sometimes even abundant (see Sample 535-76-1, 119-121 cm) for the remainder of the sequence, to total depth of the hole.

On the basis of distribution of calpionellids (see Fig. 12), two biozones, one of which is divided into two subzones, could be identified, and these range from Val- 


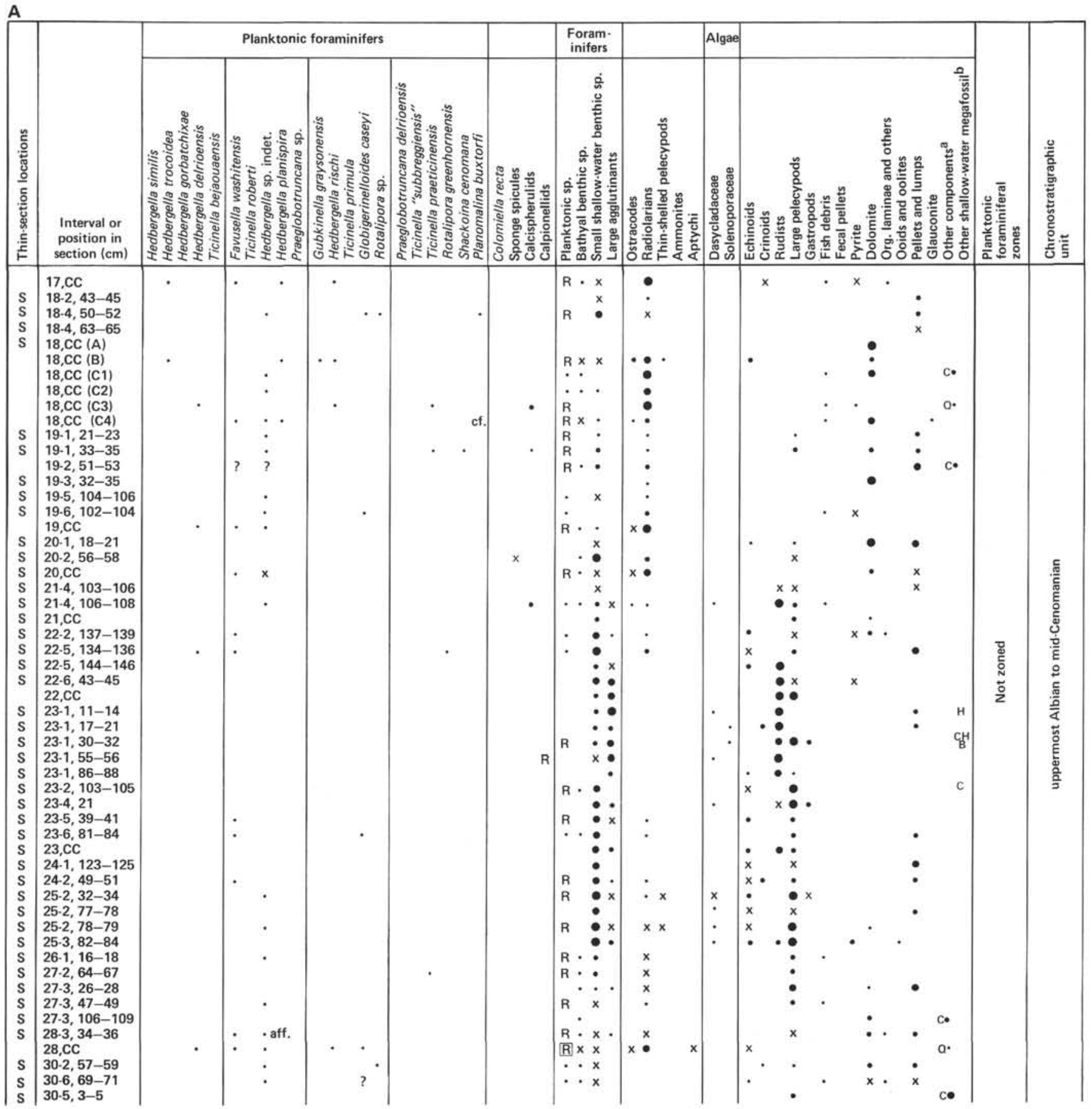

Figure 8A. Distribution of Cretaceous planktonic foraminifers, calpionellids, and associated organisms from Hole 535, Leg 77: upper part.

anginian to upper Berriasian. We discuss them now, beginning with the younger.

Calpionellites Zone $=$ Zone $\mathbf{E}$, Valanginian. Interval from $535-64-3,60 \mathrm{~cm}$ to $535-76-1,125 \mathrm{~cm}$. This zonal assemblage was traced securely from $535-71-4,39 \mathrm{~cm}$ to $535-76-1,125 \mathrm{~cm}$, on the basis of the almost constant occurrence of Calpionellites darderi, associated with Tintinnopsella longa, T. carpathica, Calpionellopsis oblon$g a$, and in the lower part with Remaniella cadischia$n a$ and rare $R$. dadayi. The upper part of the interval (535-64-3, $60 \mathrm{~cm}$ to 535-71-3) was attributed to this zone, despite the absence of Calpionellites darderi, be- cause of the occurrence of rare, long-ranging or late calpionellids (see Fig. 8C) and because nannofossil data suggest that this interval is still Valanginian (see Watkins and Bowdler, this volume). However, a dark, softer layer in Sample 535-70-1, 110-111 cm yielded a planktonic faunule consisting of poorly preserved pyritized molds of globigerinids, most of them attributable to the same species found in Sample 535-57-7, 56-59 cm, identified as upper Hauterivian. The identified species are Globuligerina hoterivica, Globuligerina $\mathrm{sp} .1$, Globuligerina sp. 2, Hedbergella? sp. 1, a single specimen of fivechambered hedbergellid, Hedbergella? sp. 2 (see Plate 1, 


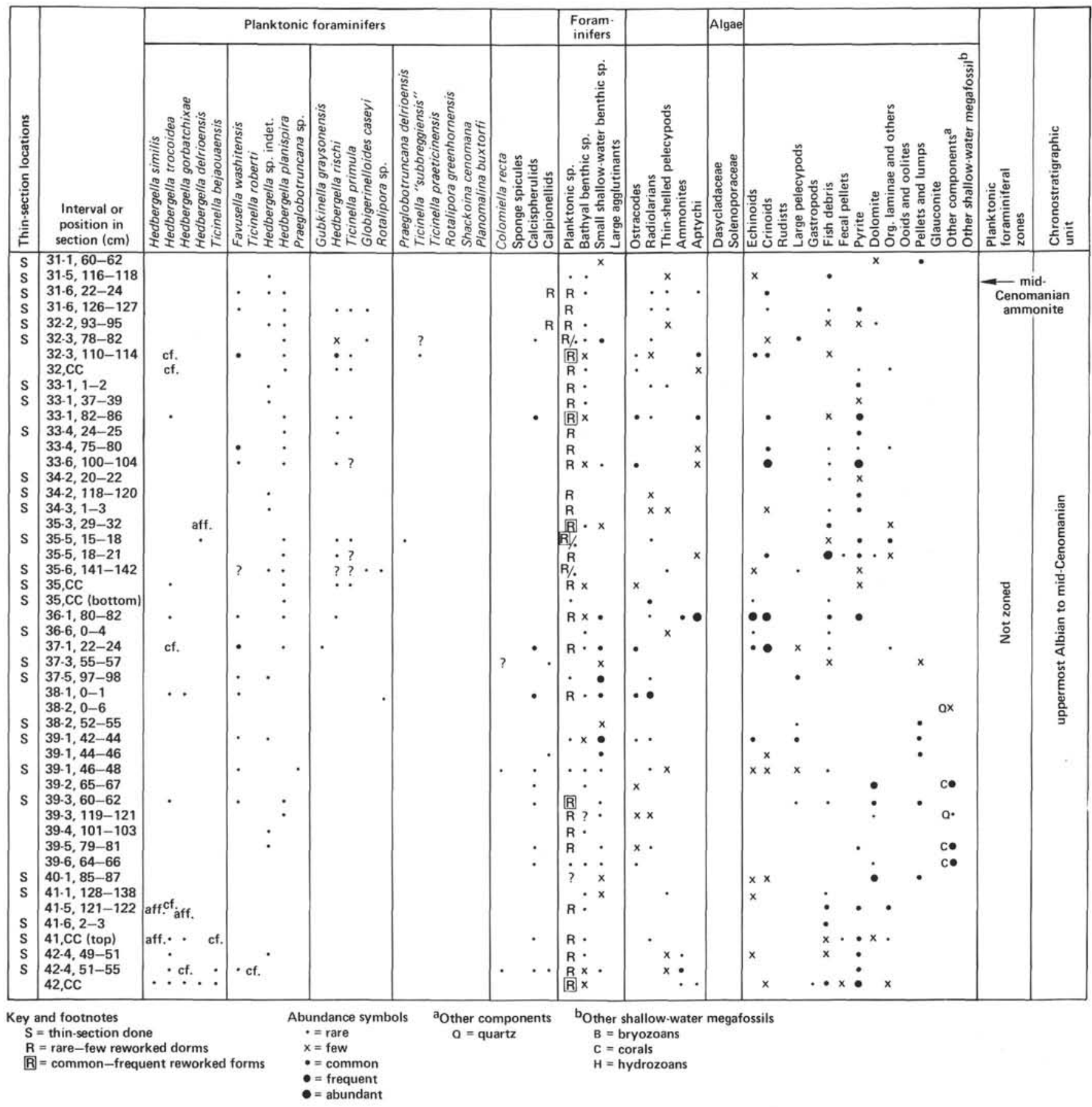

Figure 8A. (Continued).

Fig. 14), and Favusella cf. tardita. According to the recent literature (see Appendix B and Grigelis and Gorbatchik, 1980), comparable globuligerinids would not appear earlier than the Hauterivian, and the Hedbergel$l a$-like forms and Favusella tardita would indicate this section could be dated Barremian or late Hauterivian at the oldest. Consequently, their presence would contradict the Valanginian attribution inferred from calcareous nannofossils and sparse calpionellids. A possible interpretation, taking into account the transported, mixed character of the entire sedimentary sequence at Site 535 , is that nannofossils and calpionellids are reworked, and that Core 535-70-and possibly the entire sequence from Section 535-71-3, where calpionellids become rare and sparse, up to 535-64-3, $60 \mathrm{~cm}$-is in reality Barremian.

Calpionellopsis Zone $=$ Zone D, lower Valanginian to upper Berriasian (partim). Interval from 535-76-1, $125 \mathrm{~cm}$ to bottom of hole (Core 535-79-6). Calpionellids are common throughout, except in a few gray laminated limestones, which contain poorly preserved radiolarians, and in the dark, softer layers, which contain rare bathyal benthic foraminifers sometimes associated with displaced shallow-water debris. A few ammonite protoconchs and aptychi frequently occur with the calpionellids. 
Key and footnotes $S=$ thin-section don

Abundance symbols $=$ rar
$\mathrm{x}=$ few

$=$ commmon

$=$ frequent

= abundant

Other components $a=$ quartz

\footnotetext{
Figure 8B. Distribution of Cretaceous planktonic foraminifers, calpionellids, and associated organisms from Hole 535, Leg 77: middle part.
} 
On the basis of calpionellid assemblages, two subzones of Zone D were identified. They are (young to old) as follows.

1. Subzone D3: 535-76-2, $3 \mathrm{~cm}$ through 535-79-2, $28 \mathrm{~cm}$. This subzone was identified by the presence of Lorenziella hungarica (see Fig. 13) and the absence of Calpionellites darderi. Associated species are Calpionellopsis oblonga, Tintinnopsella carpathica, T. longa, and atypical Calpionella alpina. This subzone contains the Valanginian/Berriasian boundary, which falls in Section 535-77-1 between $139 \mathrm{~cm}$ and $143 \mathrm{~cm}$, corresponding to the appearance of Remaniella dadayi and Remaniella cadischiana in the upper sample. Rare Calpionellopsis simplex occurs in this interval, but the specimens are interpreted as reworked (see Fig. 12).

2. Subzone D2, upper Berriasian: $535-79-2,30 \mathrm{~cm}$ to total depth of hole. Identification of this subzone at the bottom of the hole was based on the occurrence of $\mathrm{Cal}$ pionellopsis simplex, the index species, associated with Calpionellopsis oblonga, Tintinnopsella carpathica, $T$. longa, and atypical Calpionella alpina, and the absence of Lorenziella hungarica.

\section{Basement Sites 536, 537, and 538 (Hole 538A)}

\section{Site 536}

The Cretaceous sequence recovered at Site 536, below the Paleocene/Maestrichtian boundary in Core 536-9, is somewhat different from the Cretaceous sequences at the other two basement sites, particularly because of the much younger sediments at the bottom of the hole.

Upper Maestrichtian volcaniclastic sandstones rest unconformably on bioclastic limestones, and alternate with radiolarian or planktonic foraminiferal limestones. The first lithotype dominates in the upper part of the interval, Core 536-10 to 536-15-1, $30 \mathrm{~cm}$, where pelagic limestones are rare. The lower part of the interval, above an unfossiliferous dolomite (536-15-1,31 cm to 536-21-1, $34 \mathrm{~cm}$ ), consists mainly of pelagic limestones with the minor bioclastic limestones confined to thin interbeds. The very poor core recovery prevented determination of the extent of these relations for all of the drilled interval.

Planktonic components of the pelagic limestones vary from core to core (see Fig. 9). Radiolarians dominate from 536-15-1, $31 \mathrm{~cm}$ through Core 536-19, where planktonic foraminifers are few. The remainder of the sequence (Core 536-20 to 536-21-1, $34 \mathrm{~cm}$ ) yielded few to common planktonic foraminifers, and was devoid of radiolarians. The preservation of radiolarians is very poor throughout, whereas planktonic foraminifers, although often recrystallized, could be reliably identified even in thin sections containing few samples.

Three planktonic foraminiferal zonal assemblages could be recognized; we list them from young to old.

Planomalina buxtorfi Zone, uppermost Albian (Vraconian). Interval from $536-10-1,0 \mathrm{~cm}$ to $536-11-1,15$ $\mathrm{cm}$. One layer of pelagic limestone recovered from the upper part of the considered interval yielded a few critical planktonic foraminiferal specimens, among which could be identified the zonal nominal species, Rotalipo- ra subticinensis, $R$. ticinensis, $R$. appenninica, Praeglobotruncana stephani, P. delrioensis, and Globigerinelloides caseyi. This assemblage characterizes the lower part of the Planomalina buxtorfi Zone. Radiolarians are absent.

Hedbergella gorbatchikae Zone, upper Aptian. Interval from 536-16-1, $1 \mathrm{~cm}$ to 536-20-1, 5-7 cm. Planktonic foraminifers, although never abundant, occur in most of the studied samples of this interval. Common species are the nominal species, Hedbergella trochoidea, $H$. similis, Globigerinelloides barri, and G. ferreolensis, accompanied by rare Planomalina cheniourensis and Globigerinelloides aptiensis.

Globigerinelloides algerianus Zone, upper Aptian. Interval from $536-20-1,7-8 \mathrm{~cm}$ to $536-21-1,34 \mathrm{~cm}$. The $G$. algerianus zonal assemblage was identified with certainty only in the lowermost sample of this zone (Sample 536-21-1, 32-34 cm), which yielded, besides the nominal species, several other critical forms, including Planomalina cheniourensis, Globigerinelloides barri, G. ferreolensis, Hedbergella trochoidea, $H$. similis, and $H$. delrioensis. In the studied samples above it, poorly preserved planktonic specimens could not be identified at specific levels, except for rare, long-ranging hedbergellids. The upper boundary was placed at the first occurrence of Hedbergella gorbatchikae, the index species of the overlying zone. Rare lower Aptian planktonic foraminifers are reworked into this interval.

As shown in Figure 9, the other portions of the Cretaceous sequence at Site 536 could not be zoned, because of the lack of planktonic foraminifers. Although transported from shallower environments, benthic foraminifers indicate that (1) the uppermost Albian section at Core 536-11 could be extended upward to include the entire Core 536-10, and (2) the interval from 536-13-1, $1 \mathrm{~cm}$ to $536-15-1,28 \mathrm{~cm}$ (Core 536-12 was empty) is possibly upper Aptian (see Sliter and Premoli Silva, this volume).

In conclusion, the Cretaceous sequence recovered from Hole 536 (536-10-1, $1 \mathrm{~cm}$ through 536-21-1, $34 \mathrm{~cm}$ ) ranges from uppermost Albian to upper Aptian, but it is not continuous. In fact, most of the Albian appears to be missing.

Site 537

At Site 537, which is on an unnamed, isolated, upfaulted, submarine knoll north of the Campeche Terrace, the cored contact between Cenozoic and Mesozoic sediments was strongly disturbed by coring, apparently because of different competence above and below it.

The $23 \mathrm{~cm}$ of volcaniclastic sandstone (interval 537-3-2, $20-43 \mathrm{~cm}$ ), underlying upper Paleocene chalk, is barren in the upper part, but yielded at its base foraminifers of different ages and a mixture of shallow-water debris, including (1) rare chalky globotruncanids, possibly Maestrichtian; (2) a few recrystallized lower Aptian small benthic and planktonic foraminifers; and (3) several fragments of large crinoids and echinoids, possibly lower Aptian. Below 537-3-2, $43 \mathrm{~cm}$, a piece of indurated limestone, $7 \mathrm{~cm}$ thick, was immersed in a whitish soupy chalk containing the following: a few poorly preserved 


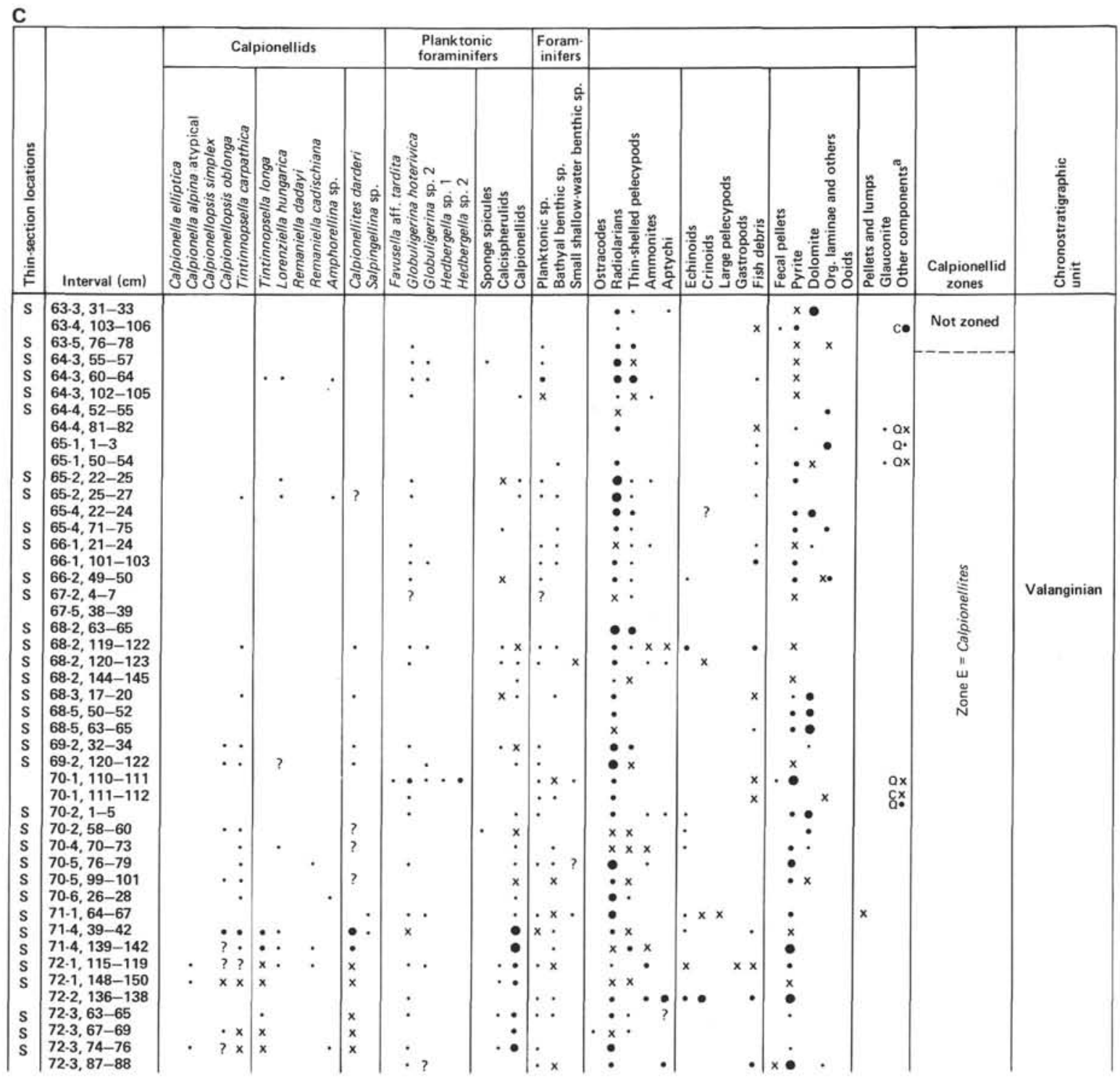

Figure 8C. Distribution of Cretaceous planktonic foraminifers, calpionellids, and associated organisms from Hole 536, Leg 77: base.

chalky planktonic foraminifers, broadly Maestrichtian; a rich, well-preserved lower Maestrichtian planktonic foraminiferal assemblage; a fairly well preserved lower Aptian planktonic foraminiferal fauna; fragments of large crinoids and echinoids; a single specimen of Pseudorbitoides (Campanian-lower Maestrichtian); and some heavily altered volcanic material. About $15 \mathrm{~cm}$ of undisturbed lower Aptian soft white chalk was recovered below 537-3-2, $57 \mathrm{~cm}$. Careful examination of the core and consideration of relative differences in preservation of the planktonic faunas in the soupy sediments led to tentative reconstruction of the sequence in Section 537-3-2, as follows (see Fig. 10):

1. From 20 to $43 \mathrm{~cm}$ : volcaniclastic sandstone yielding at the bottom rare Campanian-lower Maestrichtian shallow-water debris (Pseudorbitoides), rare Maestrichtian chalky planktonic foraminifers, and possibly some reworked lower Aptian shallow-water debris.

2. At $44 \mathrm{~cm}$ or $45 \mathrm{~cm}$ : a thin veneer, now destroyed, of soft, lower Maestrichtian chalk, containing a well- preserved planktonic foraminiferal assemblage. Species of this fauna are Globotruncana arca, G. caliciformis, G. elevata, G. fornicata, G. linneiana, G. stuartiformis, Globigerinelloides alvarezi, Rugoglobigerina sp., and Pseudoguembelina costulata, possibly of the lower Maestrichtian Globotruncana tricarinata Zone.

3. From $45 \mathrm{~cm}$ to $52 \mathrm{~cm}$ : a hardground consisting of indurated limestone with manganese and possibly phosphates, containing common, manganese-replaced tests of planktonic foraminifers, small ammonites, thin-shelled pelecypods, and rare radiolarians. Planktonic species identified in thin section are Hedbergella similis, Globigerinelloides maridalensis, Gubkinella sp., and Globuligerina hoterivica, among others. No globotruncanids were detected in this layer.

4. From $53 \mathrm{~cm}$ to $75 \mathrm{~cm}$ : soft white chalk yielding abundant recrystallized planktonic foraminifers, a few small, shallow-water and bathyal benthic foraminifers, and abundant fragments of large crinoids and echinoids. Planktonic species are correlative with the lower Apti- 


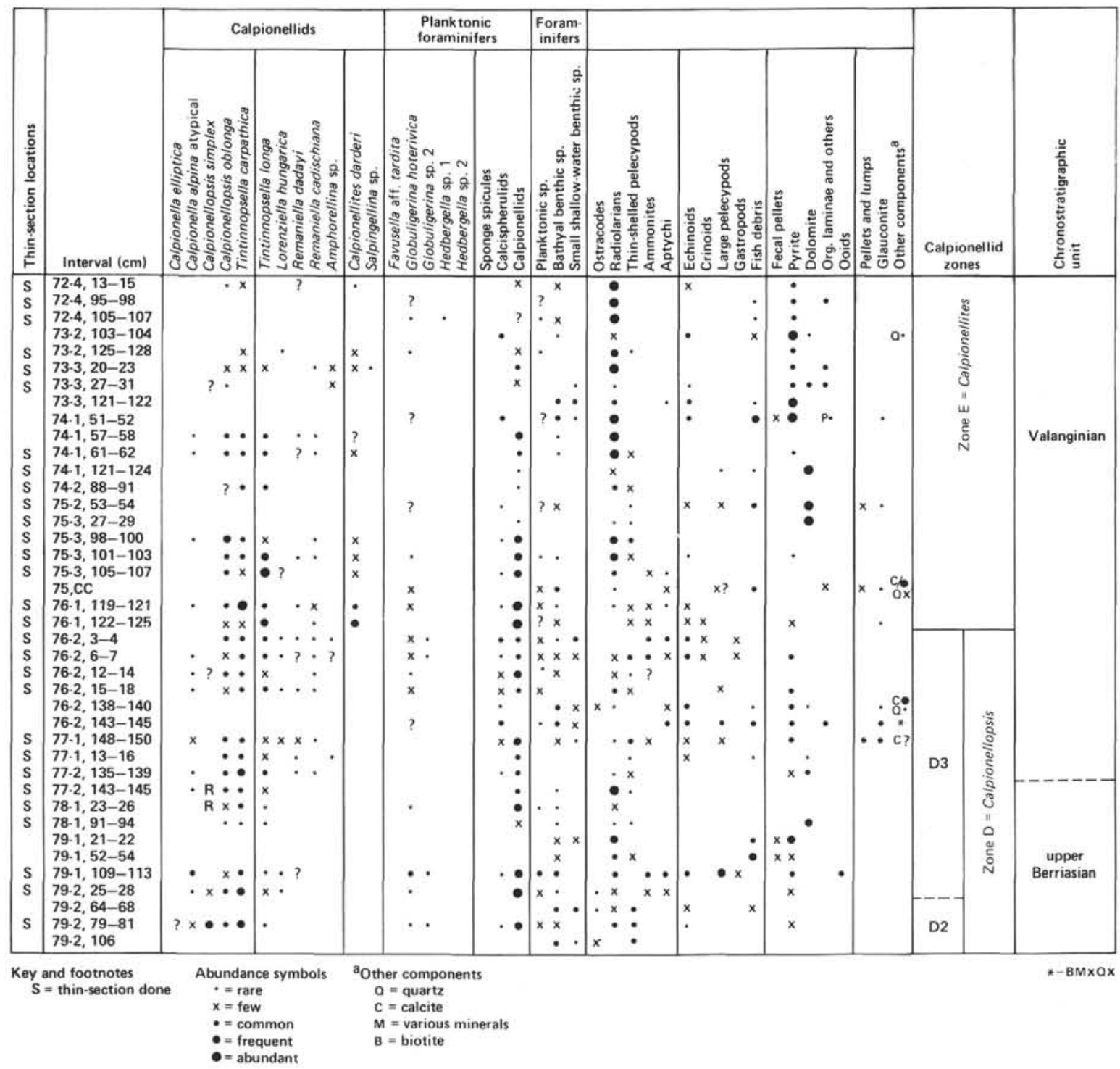

Figure 8C. (Continued).

an Globigerinelloides gottisi/Globigerinelloides duboisi Zone, on the basis of the presence of the two index species associated with Hedbergella similis, $H$. sigali, and Gubkinella sp.

Below the lower Aptian chalk is an interval (Cores 537-4 through 537-10) of bioclastic limestone, for which the core recovery was very poor (only $4 \%$ of the total interval). The only planktonic forms in the interval are rare calpionellids, which were found in several chips of the rubbly recoveries (see Fig. 10).

Several species of calpionellids were identified in thin section and found in the matrix between the large shallow-water bioclasts. They are missing in Core 537-4, occur from Core 537-5 through Core 537-10, but are represented mainly by one to very few specimens per sample.

Three assemblages, corresponding to the three subzones of the Calpionellopsis Zone (Zone D) could be recognized. From young to old, they are as follows.

Subzone D3. Cores 537-5 and 537-6, on the basis of the occurrence of Calpionellopsis oblonga, Tintinnop- sella carpathica, T. longa, and atypical Calpionella alpi$n a$. A single specimen of Remaniella dadayi was found in Sample 537-5-1, 37-38 cm, associated with $R$. cadischiana, whereas Lorenziella hungarica was found only in Sample 537-5-1, 24-25 cm.

Subzone D2. Core 537-7, on the basis of the occurrence of Calpionellopsis simplex and C. oblonga.

Subzone D1. Core 537-10, on the basis of the occurrence of Calpionellopsis simplex and Calpionella alpi$n a$. The $C$. elliptica and Remaniella ferasini found in Sample 537-10, 23-24 cm must be reworked.

According to the distribution of calpionellids (see Fig. 12), the interval from Cores 537-10 to 537-6 should be upper Berriasian, and Core 537-5 should be lowermost Valanginian because of the occurrence of Remaniella dadayi, but these attributions are in disagreement with those inferred from benthic foraminifers. For example, the lowermost sample of this interval, 537-10-1, 23-24 cm, yielded specimens of Trocholina infragranulata, which has not been reported below the Valanginian 


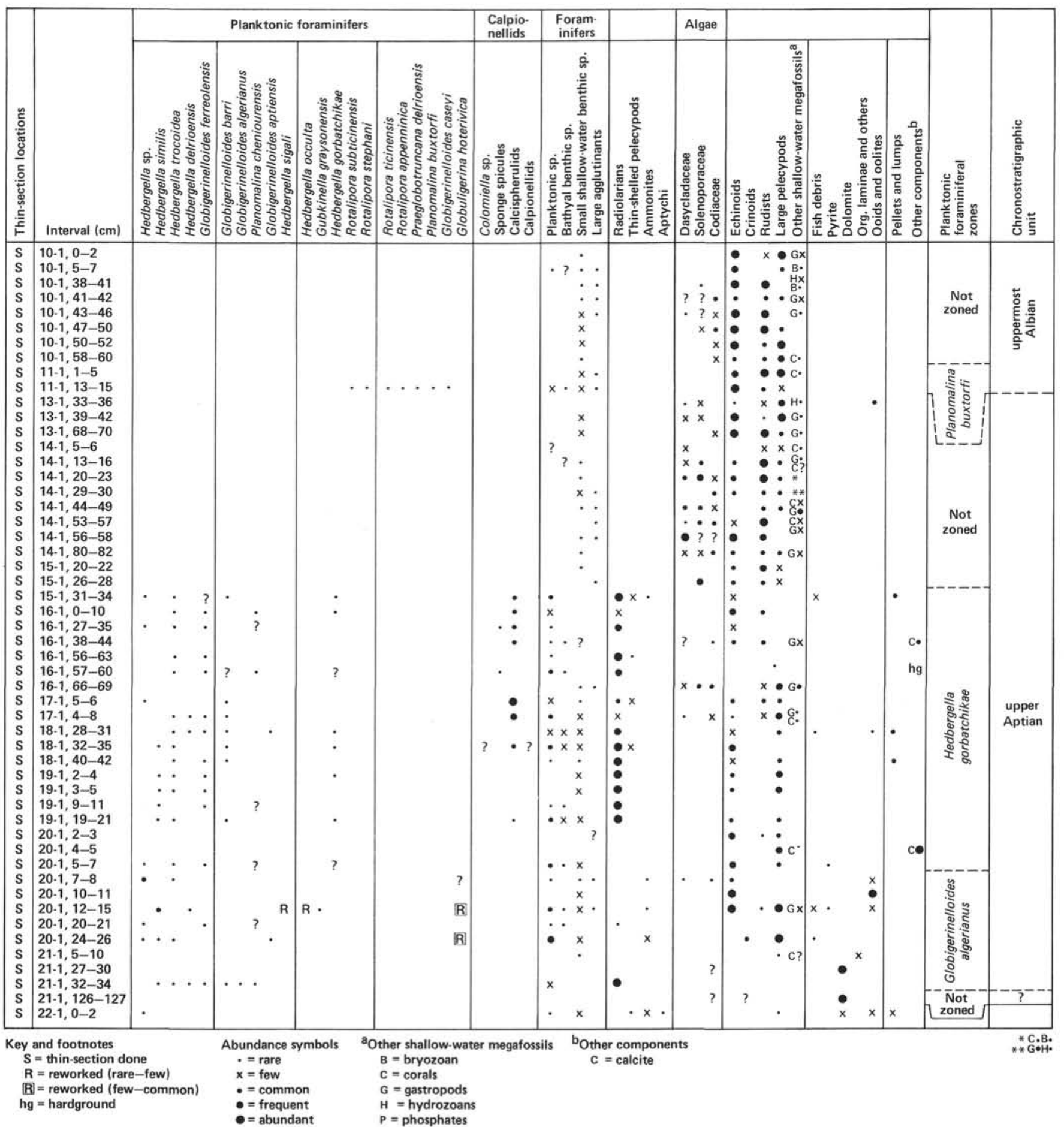

Figure 9. Distribution of Cretaceous planktonic foraminifers and associated organisms from Hole 536, Leg 77.

(see Sliter and Premoli Silva, this volume) and which suggests that the Berriasian calpionellids are reworked. Another trocholinid close to Trocholina friburgensis, found from $537-10-1,13 \mathrm{~cm}$ to $537-5-1,7-8 \mathrm{~cm}$, would suggest an age even younger than Valanginian. Also, benthic foraminifers indicate that reworking involved even Jurassic terrains. Consequently, for the time being, the interval is assigned to the Valanginian, but it may belong to a younger Lower Cretaceous unit.

The fossiliferous sequence in Hole 537 ends at 537$11-1,137 \mathrm{~cm}$. The $137 \mathrm{~cm}$ of silty marls yielded only rare, small bathyal benthic foraminifers in a large amount of crinoid fragments and ostracodes. According to Oertli (this volume), the ostracode fauna suggests that the up- 


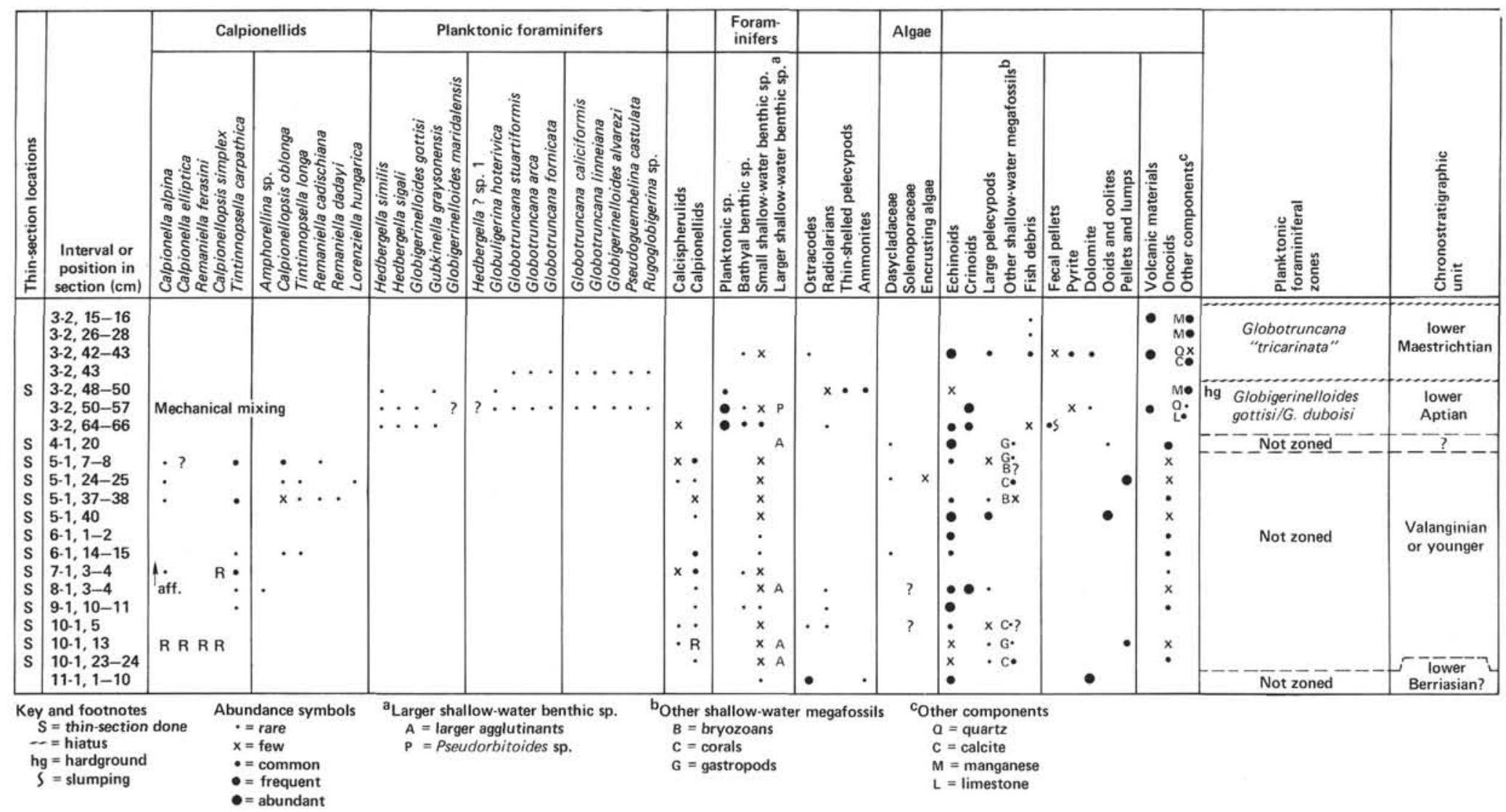

Figure 10. Distribution of Cretaceous planktonic foraminifers, calpionellids, and associated organisms from Hole 537, Leg 77. 


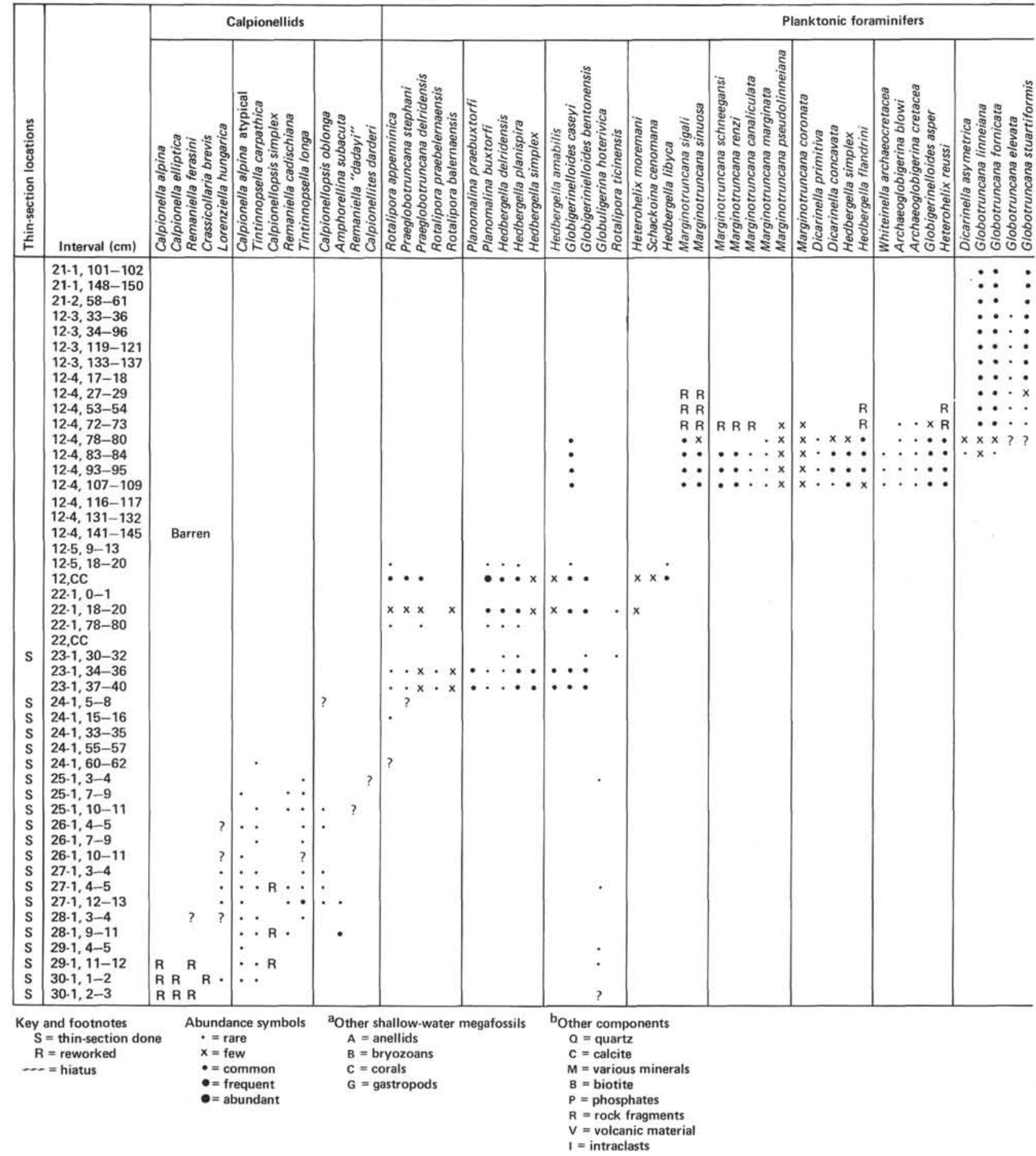

Figure 11. Distribution of Cretaceous planktonic foraminifers, calpionellids, and associated organisms from Hole 538A, Leg 77.

per part of Core $537-11$ is lowermost Cretaceous, and it was plotted accordingly in Figure 6.

The remaining sediments from 537-11-1, $138 \mathrm{~cm}$ through Core 537-13, resting on basement are devoid of fossils, and could not be dated.

\section{Site 538 (Hole 538A)}

Hole 538A, located in Catoche Knoll, a high-standing fault block to the east of Site 537 , is the only hole among those drilled during Leg 77 in which some short parts of Upper Cretaceous were recorded.

As mentioned previously, the boundary between the Cenozoic and the Mesozoic in Hole 538A is marked by a discrete hardground, with manganese-encrusted upper Paleocene planktonic foraminifers, resting on upper Maestrichtian light foraminifer-nannofossil chalk (Section 538A-21-1 at $59 \mathrm{~cm}$ ) (see Figs. 5 and 11). An apparently uniform interval of mainly foraminifer-nannofossil chalk 


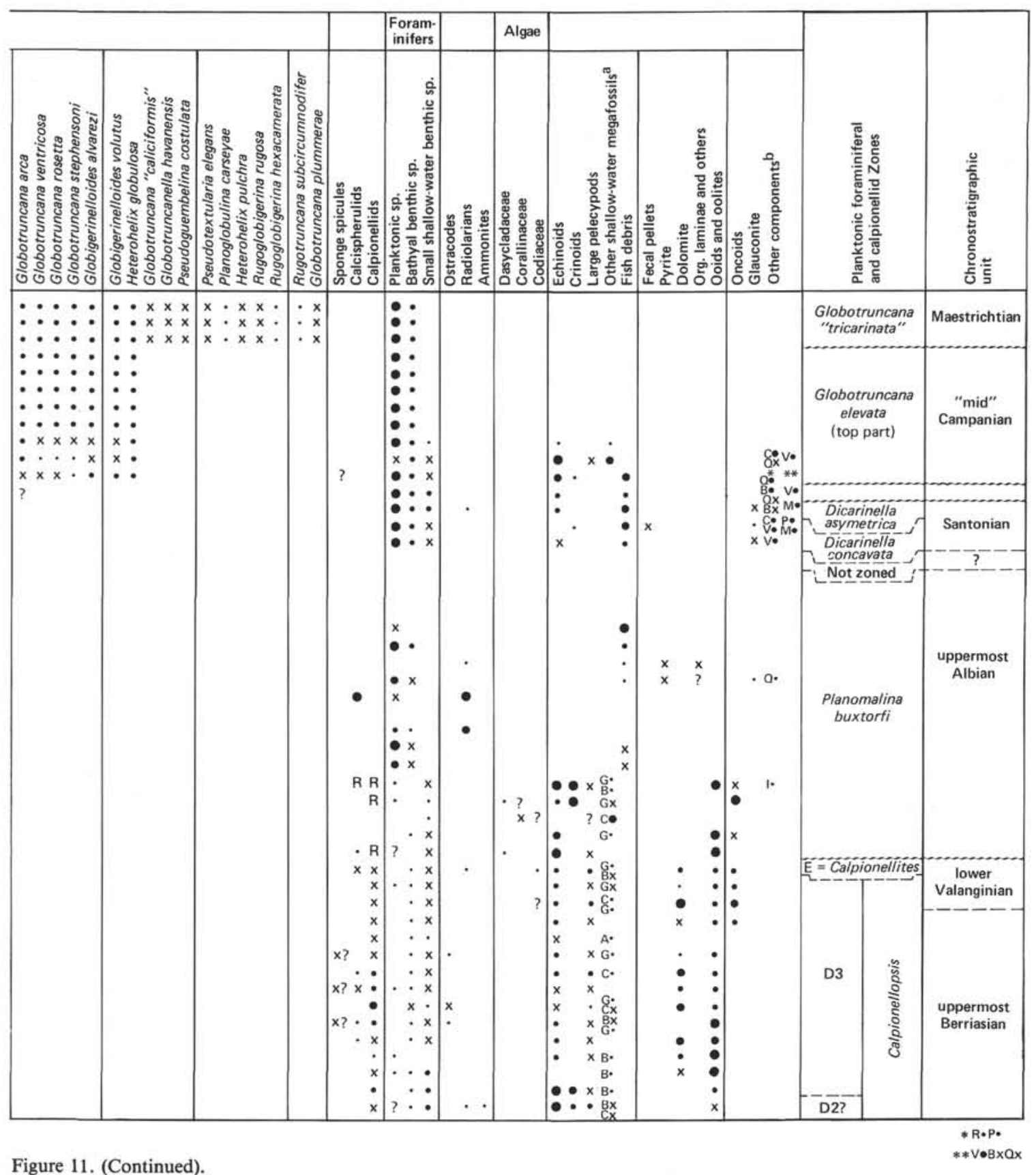

extends from the hardground at $538 \mathrm{~A}-21-1,59 \mathrm{~cm}$ to 538A-21-4, $110 \mathrm{~cm}$. However, this 5-m interval represents a condensed sequence ranging from lower Maestrichtian at the top to Santonian at the bottom and interrupted by a few hiatuses as much as several million years long. The recognized planktonic foraminiferal assemblages are as follows (from young to old).

Globotruncana tricarinata Zone, lower Maestrichtian. Interval from $538 \mathrm{~A}-21-1,60 \mathrm{~cm}$ to $538 \mathrm{~A}-21-2,125 \mathrm{~cm}$. This assemblage was correlated with the Globotruncana tricarinata Zone on the basis of the occurrence of Globotruncanella havanensis, Rugotruncana subcircumnodifer, Globotruncana plummerae, G. caliciformis, Rugoglobigerina hexacamerata, Planoglobulina carseyi, associated with $G$. arca, G. rosetta, G. stuartiformis, G. ventricosa, and Pseudotextularia elegans.
Globotruncana elevata Zone, mid-Campanian. Interval from 538A-21-2, $126 \mathrm{~cm}$ to 538A-21-4, $75 \mathrm{~cm}$. Common species in this interval are Globotruncana arca, $G$. elevata, G. fornicata, G. linneiana, G. rosetta, G. stephensoni, G. stuartiformis, and $G$. ventricosa. This assemblage characterizes the middle part of the Globotruncana elevata Zone.

No lithologic break was detectable at $125 \mathrm{~cm}$ in Section 538A-21-2 to account for the absence of the upper Campanian Globotruncana calcarata and Globotruncana subspinosa zones.

In the lowermost $65 \mathrm{~cm}$ of the Globotruncana elevata Zone (Interval 538A-21-4, 10-75 cm), mid-Campanian sediments become coarser than the overlying chalk. This graded interval contains fragments of ash layers, Campanian neritic benthic foraminifers, Lower Cretaceous 
shallow-water debris, and a few lower Santonian planktonic foraminifers, mixed within the autochthonous Campanian lower bathyal benthic and planktonic foraminifers. The allochthonous material is very abundant at the base of the layer, and decreases gradually upward to 538A-21-4, $29 \mathrm{~cm}$, where it is a minor component.

From 538A-21-4, $75 \mathrm{~cm}$ to $538 \mathrm{~A}-21-4,109 \mathrm{~cm}$, dominantly pelagic but coarser sediments alternate with a few discrete ash layers. The uppermost layer (Sample 538A-21-4, 78-81 cm) yielded a mixed assemblage consisting of a few Campanian planktonic and bathyal benthic foraminifers and abundant Santonian planktonic foraminifers, accompanied by a few obviously reworked Lower Cretaceous shallow-water benthic foraminifers and skeletal debris. It is not clear whether the Campanian foraminifers are drilling contaminants in a Santonian interval or the Santonian faunas, like the Lower Cretaceous skeletal debris, are reworked into Campanian sediments. Consequently, the oldest planktonic foraminiferal assemblage was found in Sample 538A-21-4, 75-81 $\mathrm{cm}$, and is characteristic of the upper Santonian Dicarinella asymmetrica Zone, which can be extended downward to 538A-21-4, $85 \mathrm{~cm}$. The fauna contains Dicarinella asymetrica, D. concavata, Hedbergella flandrini, Archaeoglobigerina cretacea, A. blowi, rare Globotruncana linneiana, and $G$. fornicata, and several species of marginotruncanids.

Sediments from 538A-21-4, $85 \mathrm{~cm}$ to $538 \mathrm{~A}-21-4,109$ $\mathrm{cm}$ contain planktonic foraminifers equivalent to the lower Santonian Dicarinella concavata Zone, in the absence of Dicarinella asymetrica. Planktonic assemblages are dominated by marginotruncanids associated with the index species, Dicarinella primitiva, Hedbergella flandrini, H. simplex, Heterohelix reussi, Whiteinella archaeocretacea, Archaeoglobigerina blowi, and A. cretacea, among others.

Lower Cretaceous shallow-water benthic foraminifers and skeletal debris occur in some amount throughout the interval from 538A-21-4, $78 \mathrm{~cm}$ to $538 \mathrm{~A}-21-4,109 \mathrm{~cm}$, mixed within the autochthonous planktonic and bathyal faunas.

At $100 \mathrm{~cm}$ in Section 538A-21-4, the sequence is truncated by a fault which marks another hiatus. Below the fault, from $538 \mathrm{~A}-21-4,110 \mathrm{~cm}$ to $538 \mathrm{~A}-21-5,18 \mathrm{~cm}$, sediments consist of yellowish, then green claystones, which are barren.

At $18 \mathrm{~cm}$ in Section 538A-21-5, a sharp lithologic change occurs, below which nannofossil chalks interbedded with limestone and chert are encountered downward through Core 538A-23. Soft nannofossil chalk layers yielded rich and well-diversified planktonic faunas, whereas the hard layers contain abundant recrystallized radiolarians. Planktonic foraminifers permit assignment of the whole interval to the uppermost Albian (Vraconian). In particular, planktonic assemblages are attributable to the Planomalina buxtorfi Zone, on the basis of the occurrence of the nominal species, common Rotalipor appenninica, $R$. balernaesis, Praeglobotruncana stephani, P. delrioensis, Hedbergella planispira, H. amabilis, H. simplex, and Globigerinelloids bentonensis, and fewer Planomalina praebuxtorfi and Rotalipora praeba- lernaensis in the lower levels of Core 538A-23. Fish debris is common in some layers (e.g., Sample 538A-21-5, $18-20 \mathrm{~cm})$. Few shallow-water benthic foraminifers and debris also are mixed with the autochthonous bathyal benthic and planktonic faunas of some layers.

From Core 538A-24 to 538A-30-1, $5 \mathrm{~cm}$, sediments consist of skeletal limestone, except for a thin veneer of nannofossil chalk, which coats the metamorphic rocks of the basement at $6 \mathrm{~cm}$ in Section 538A-30-1. The recovery was very poor in this interval, averaging $2.8 \%$ of the total interval, which is lower than that recorded for comparable lithology in Hole 537.

Planktonic forms are rare in this unit, but they include age-diagnostic forms. Three specimens of planktonic foraminifers were found in the matrix of grainstones in Core 538A-24, where there are also a few oncoids enveloping rare specimens of calpionellids (see Sliter and Premoli Silva, figures $8 \mathrm{~A}-8 \mathrm{C}$, this volume). The planktonic foraminifers are attributable to the $R$. appenninica and Praeglobotruncana stephani groups, suggesting that Core 538A-24 belongs to the Planomalina buxtorfi Zone of the overlying Section 538A-21-5 through Core 538A-23.

In the interval from Core $538 \mathrm{~A}-25$ to $538 \mathrm{~A}-30-1,5 \mathrm{~cm}$, calpionellids commonly occur, sometimes with few Globuligerina hoterivica and very rare radiolarians, and usually within the nannoconid micrite that appears to cement the bioclasts (see Sliter and Premoli Silva, Figure $8 \mathrm{E}-\mathrm{G}$, this volume). On the basis of calpionellids, this interval ranges from uppermost Berriasian to lowermost Valanginian, which is in agreement with the age indicated by calcareous nannofossils for the chalk veneer resting on basement rocks (see Watkins and Bowlder, this volume). Consequently, a large hiatus, spanning most of the Albian through most of the Valanginian, must occur between Core 538A-24 and Core 538A-25, even taking into account the poor recovery.

Most calpionellid assemblages of the interval belong to Subzone D3 of the Calpionellopsis Zone (Zone D), except possibly for the topmost sample, 538A-25-1, 3-4 cm, and the lowermost sample, 538A-30-1, 2-3 cm. The zonal assignment is based on the occurrence of Lorenziella hungarica, which appears in Sample 538A-30-1, 1-2 cm (see Plate 6, Fig. 5), and the absence of Calpionellites darderi (see Fig. 12). Intermittent in this interval are Tintinnopsella carpathica, T. longa, Calpionellopsis oblonga, and Remaniella cadischiana. A possible Remaniella dadayi in Sample 538A-25-1, 10-11 cm suggests that the Berriasian/Valanginian boundary falls between Cores 538A-25 and 538A-26. Calpionellids reworked from older layers are common throughout the interval. The presence of specimens attributable to Crassicollaria brevis indicates that reworking involved also uppermost Jurassic (upper Tithonian), as well as the more common lower Berriasian, forms.

A doubtful specimen of Calpionellites darderi was found in Sample 538A-25-1, 3-4 cm, suggesting that the topmost part of Core 538A-25 belongs to the lower Valanginian Calpionellites Zone (Zone E). The lowermost sample, 538A-30-1, 2-3 cm, contained a calpionellid assemblage characteristic of the lower Berriasian Calpio- 


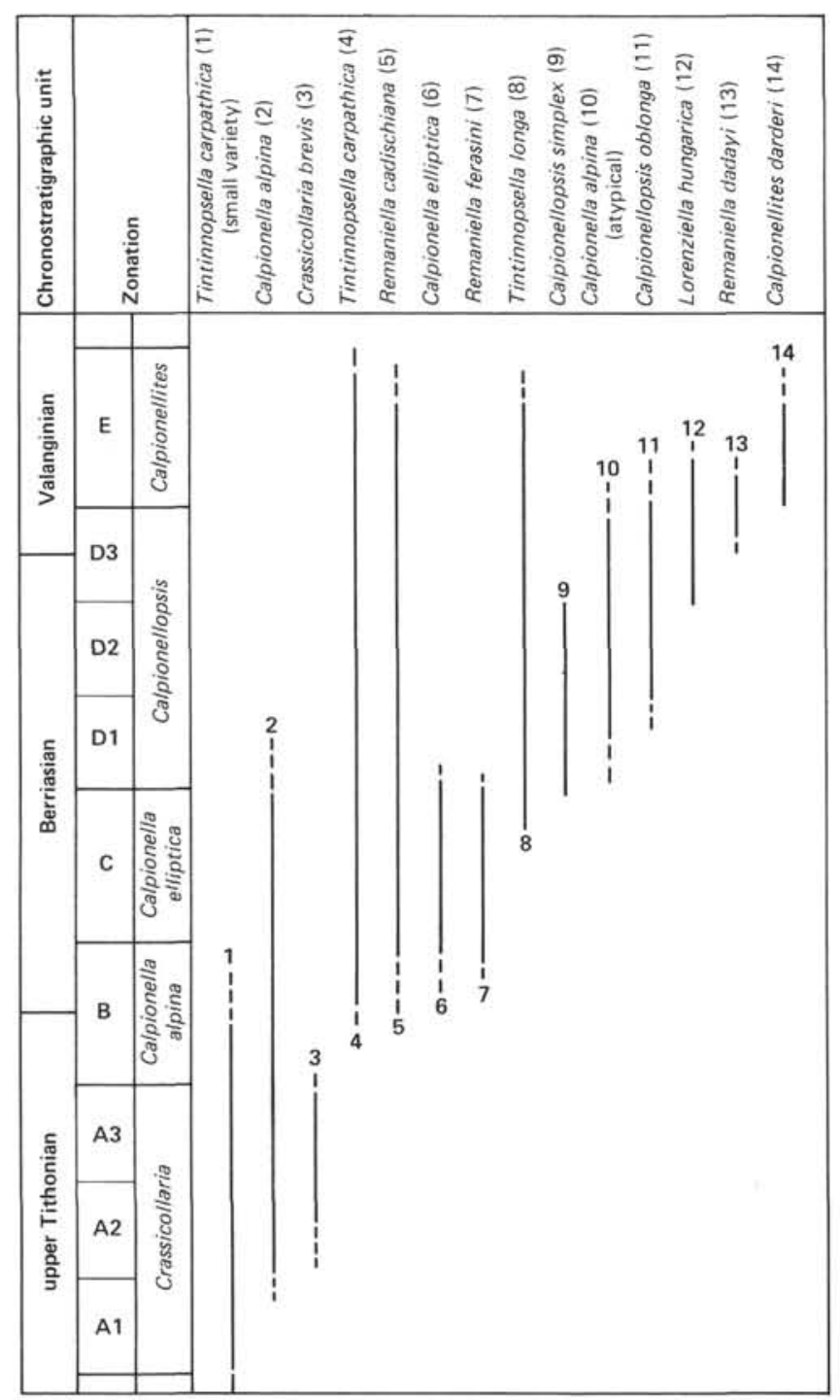

Figure 12. Distribution of selected calpionellids in Tethyan realm (compiled after Neagu, 1975; Catalano and Liguori, 1970; Remane, 1978; Sironi Cita, 1964).

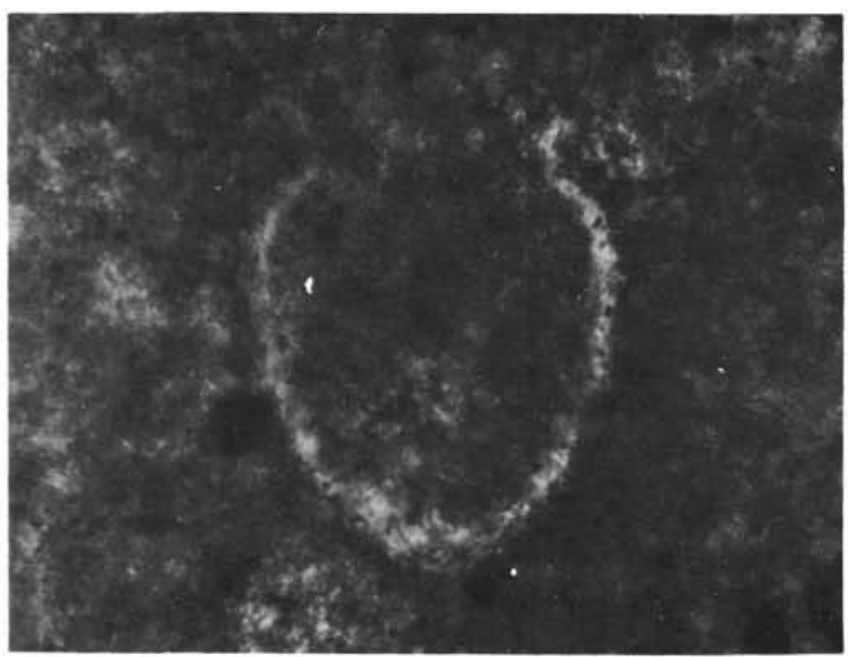

Figure 13. Lorenziella hungarica Knauer and Nagy. Sample 535-79-2, 23-28 cm, upper Berriasian; magnified $\times 600$. nella elliptica Zone (Zone C), on the basis of the occurrence of the nominal species, Calpionella alpina (typical), and Remaniella ferasini (see Fig. 12). If this zonal attribution is accepted, a hiatus spanning the upper Berriasian Subzones D2 and D1 must be inferred between samples at $1-2 \mathrm{~cm}$ and $2-3 \mathrm{~cm}$ in Section 538A-30-1. An alternative hypothesis could be that the $C$. elliptica zonal assemblage is reworked, as noted for several other species in the overlying cores, and that Sample 538A-30-1, $2-3 \mathrm{~cm}$ is in continuity with Subzone D3, is equivalent to the youngest portion of Subzone D2, and is upper Berriasian.

Contrary to the results at Site 537, the uppermost Berriasian to lower Valanginian assignment for the interval of 538A-30-1, $5 \mathrm{~cm}$ through Core 538A-25, based on calpionellids, is apparently in agreement with the age inferred from benthic foraminifers. Moreover, benthic foraminiferal content does not contradict the uppermost Albian attribution of Core 538A-24.

\section{CONCLUSIONS}

In spite of the difficulties encountered in deciphering the extremely complex sedimentological and biostratigraphic records from all sites drilled during Leg 77, a few tentative conclusions can be drawn.

1. The biostratigraphic data show that times of contemporaneous sedimentation in the area of study in the southeastern Gulf of Mexico were as few in the Cretaceous as they were during the Cenozoic.

The somewhat extended episodes were as follows:

A. Early Maestrichtian, when the Globotruncana tricarinata zonal assemblages were deposited at Sites 537, 538 (Hole 538A), and 540.

B. Latest Albian, when the Planomalina buxtorfi zonal sediments were deposted at Sites 536, 538 (Hole 538A) and 540 . Sediments of the same age were also deposited at an upslope location close to Site 535 (now reworked within Site 535 sequence).

C. Part of the late Aptian, corresponding to the Hedbergella gorbatchikae Zone, recorded at Sites 535 and 536.

D. Part of the early Aptian, corresponding to the Globigerinelloides gottisi/G. duboisi Zone, recorded at Sites 535 and 537, and possibly at an upslope location close to Site 536 (now reworked within Site 536 sequence).

E. Early Valanginian to latest Berriasian, corresponding to the Calpionellites Zone through the top of Subzone D2 at Site 535 and in Hole 538A, and at an upslope location close to Site 537 (now reworked within Site 537 sequence).

The remainder of the Cretaceous consisted of times of nondeposition at most of the drilled locations.

2. The most nearly complete Cretaceous sequence was found along the Florida transect by combining the two successions recovered at Sites 540 and 535. However, there the dominance of clastic sedimentation created severe problems of correlation between the two sequences and of age-dating important portions of them.

Several problems remain after this study:

A. The interval from $540-32-1,18 \mathrm{~cm}$ to $540-45, \mathrm{CC}$ at Site 540 and the interval from Core $535-17, \mathrm{CC}$ to 
Core 535-43-2 plus Core 535-45,CC at Site 535 seem to overlap, but the latter may belong to a giant slumping carried downslope later in the Cretaceous, postdating in any case their apparent middle Cenomanian to latest $\mathrm{Al}$ bian times of initial deposition.

B. The interval from 535-64-3, $60 \mathrm{~cm}$ to Section 535-71-3 at Site 535 may be as young as the Barremian. This would require a younger age for the overlying interval (535-48 to 535-64-3, $60 \mathrm{~cm})$. In such a circumstance a large hiatus spanning the Hauterivian and possibly the upper Valanginian would exist between Section 535-71-3 and $535-71-4,39 \mathrm{~cm}$, instead of a continuous sequence, as plotted now in Figure 6.

C. The recovery of juvenile ammonites from the Cretaceous of Site 535 causes problems in interpretation of that section (see Young, this volume).

D. All fossils of Hole 535 (including calpionellids) may be reworked (in spite of their apparent stratigraphic order). The reworking must be considered because of the persistence of shallow-water materials throughout the sedimentary sequence, even in the lowermost layer at $535-79-2,106 \mathrm{~cm}$.

E. The inferred ages presented in this study are not definite, and future drilling where sequences appear undisturbed on seismic lines may help reconstruct reliably the biostratigraphic and sedimentary record of this part of the Gulf.

3. The basal sediments of the basement sites are of different facies and age.

A. In Hole 538A a Berriasian pelagic chalk coats $\mathrm{Pa}$ leozoic metamorphic rock of the basement. At Site 537 lowermost Cretaceous is underlain by undated continental deposits, which lie on continental basement. At Site 536 the basement was not reached, but pelagic upper Aptian lies on dolomite that could predate the Cretaceous.

B. At fault-block Sites 537 and 538, open marine conditions were established by earliest Cretaceous time, and the basement had subsided earlier to bathyal depths to receive the combined shelf debris and plankton fall. Site 538 may have reached such conditions earlier, judging from the reworked Tithonian calpionellids in Hole 538A.

4. The fault blocks at Sites 537 and 538 were uplifted during the Paleogene, as indicated by the end of abundant displaced and reworked material. At Site 538 this occurred at the end of the early Eocene, after the end of the youngest slump. The lack of submarine topographic distinction at Site 536 suggests that the Tertiary uplift did not occur or was subsequently hidden by sedimentation on the Campeche Terrace.

\section{ACKNOWLEDGMENTS}

The authors thank the Deep Sea Drilling Project for the opportunity to join the Shipboard Scientific Party of Leg 77, and their respective institutions for leave of absence to participate in the cruise.

Particularly, we are indebted to the following at the University of Milan: Elisabetta Erba and Barbara Quadrio for help in drafting and checking figures, accumulating references, and many similar tasks; Gabriele Pezzi for preparation of samples, and Agostino Rizzi for
SEM photomicrographs. The study was supported in part by CNR of Italy, Comitato 05, IPS, Unità di Ricerca di Milano, Cruppo Informale "Paleontologia Stratigrafica ed Evoluzione."

For critical reading of the manuscript and the resulting improvement, we are grateful to Maria Cita of the Department of Earth Sciences, University of Milan.

\section{REFERENCES}

Blauser, W. H., and McNulty, C. L., 1980. Calpionellids and nannoconids of the Taraises Formation (Early Cretaceous) in Santa Rosa Canyon, Sierra de Santa Rosa, Nuevo Leon, Mexico. Gulf Coast Assoc. Geol. Soc. Trans., 30:263-272.

Catalano, R., and Liguori, U., 1971. Facies a Calpionelle della Sicilia occidentale. In Farinacci, A. (Ed.), Proc. II Plankt. Conf. Roma: Rome (Edizioni Tecnoscienza), 1:167-210.

Ellis, B. F., and Messina, A., 1940 et seq. Catalogue of Foraminifera: New York (Am. Mus. Nat. Hist.).

Fuchs, W., 1971. Eine alpine Foraminiferenfauna des tieferen MittelBarrême aux den Drusbergschichten vom Ranzenberg bei Hohenems in Vorarlberg. Abh. Geol. Bundes., 27.

Gorbatchik, T. N., and Poroshina, L. A., 1979. New planktonic Foraminifera from Berriasian deposits of Azerbaizhan. Paleont., 3: 22-28.

Grigelis, A., and Gorbatchik, T. N., 1980. Morphology and taxonomy of Jurassic and Early Cretaceous representatives of the superfamily Globigerinacea (Favusellidae). Foram. Res., 10(3):180-190.

Longoria, J. F., 1974. Stratigraphic, morphologic and taxonomic studies of Aptian planktonic Foraminifera. Rev. Esp. Micropaleont., (No. extra Dec. 1974): 1-134.

McNulty, C. L., 1979. Smaller Cretaceous foraminifers of Leg 43, Deep Sea Drilling Project. In Tucholke, B. E., Vogt, P.R., et al., Init. Repts. DSDP, 43: Washington (U.S. Govt. Printing Office), 487-505.

Moullade, M., 1966. Etude stratigraphique et micropaléontologique du Crétacé inférieur de la "Fosse Vocontienne". Doc. Lab. Geol. Fac. Sci. Lyon, 15:1-369.

Neagu, T., 1975. Microbiostratigraphy of the Eocretaceous from Dimbovicioara Passage and adjacent area. Guide-Book 14th Europ. Micropal. Colloquium (Inst. Geol. Geoph. Bucuresti), pp. 99-105.

Pessagno, E. A., Jr., 1967. Upper Cretaceous planktonic Foraminifera from the western Gulf Coastal Plain. Paleontogr. Am., 37:1-455.

Premoli Silva, I., and Boersma, A., 1977. Cretaceous planktonic Foraminifera of DSDP Leg 39, South Atlantic. In Supko, P. R., PerchNielsen, K., et al., Init. Repts. DSDP, 39: Washington (U.S. Govt. Printing Office), 615-641.

Remane, J., 1964. Untersuchungen zur Systematik and Stratigraphie der Calpionellen in den Jura-Kreide-Grenzschichten des Vocontischen Troges. Palaeontrographica (A), 123:1-57.

1978. Calpionellids. In Haq, B. U., and Boersma, A. (Eds.), Introduction to Marine Micropaleontology: New York (Elsevier), pp. 161-170.

Robaszynski, F., and Caron, M. (Coord.), 1979a. Atlas des Foraminifères planctoniques du Crétacé moyen (Mer Boréale et Téthys). Cah. Micropaleontol., 1:1-185.

1979b. Atlas des Foraminifères planctoniques du Crétacé moyen (Mer Boréale et Téthys). Cah. Micropaleontol., 2:1-181.

Roesler, W., Lutze, G. F., and Pflaumann, U., 1979. Some Cretaceous planktonic foraminifers (Favusella) of DSDP Site 397 (eastern North Atlantic). In von Rad, U., Ryan, W. B. F., et al., Init. Repts. DSDP , 47, Pt. 1: Washington (U.S. Govt. Printing Office), 273-281.

Ross, M. A., and McNulty, C. L., 1981. Some microfossils of the Tamaulipas Limestone (Hauterivian-Lower Albian) in Santa Rosa Canyon, Sierra de Santa Rosa, Nuevo Leon, Mexico, Gulf Coast Assoc. Geol. Soc. Trans. Suppl., 31:461-469.

Schlager, W., Buffler, R. T., and Shipboard Scientific Party, 1984. Deep Sea Drilling Project Leg 77, Southeastern Gulf of Mexico. Geol. Soc. Am. Bull., 95:226-236.

Sigal, J., 1966. Contribution à une monographie des Rosalines. 1. Le genre Ticinella Reichel, souche des Rotalipores. Eclogae Geol. Helv., 59(1):185-218.

, 1967. Contribution à une monographie des Rosalines. 2. L'éspèce Rotalipora appenninica (Renz O., 1936), origine phyletique et taxonomique. In Brönniman, P., and Renz, H. H. (Eds.), 
Proc. First Int. Conf. Plankt. Microfossils: Leiden (E. J. Brill), 2: 622-639.

1979. Chronostratigraphy and ecostratigraphy of Cretaceous formations recovered on DSDP Leg 47B, Site 398. In Sibuet, J.-C., Ryan, W. B. F., et al, Init. Repts. DSDP, 47, Pt. 2: Washington (U.S. Govt. Printing Office), 287-326.

Sironi Cita, M. B., 1964. Ricerche micropaleontologiche e stratigrafiche sui sedimenti pelagici del Giurassico superiore e del Cretaceo inferiore nella Catena del Monte Baldo. Riv. Ital. Paleont. Strat. Mem., 10.

Sliter, W. V., 1968. Upper Cretaceous Foraminifera from Southern California and North-western Baja California, Mexico. Kansas Univ. Paleont. Contr., 7:657-697.

Subbotina, N. N., 1953. Fossil Foraminifera of the USSR, Globigerinidae, Hantkeninidae, and Globorotaliidae. Trudy VNIGRI, 76.

Date of Initial Receipt: May 11, 1983

Date of Acceptance: October 7, 1983

\section{APPENDIX A}

List of Identified Species (Cretaceous) ${ }^{3}$

\section{Calpionellids}

Amphorellina subacuta Colom, 1948. See Blauser and McNulty (1980), pl. 1, fig. 1.

Calpionella alpina Lorenz, 1902. See Remane (1964), pl. 1, figs. 1-21, 24 ; pl. 5, figs. 2, 4-7.

Calpionella alpina atypica. See Remane (1978), fig. 8/17.

Calpionella elliptica Cadisch, 1932. See Remane (1964), pl. 1, figs. 27, $32-43$; pl. 5, figs. 8-11.

Calpionellites darderi (Colom, 1934) (= Calpionella darderi Colom). See Catalano and Liguori 91970), pl. 5, figs. 10-15; text-fig. 14h.

Calpionellopsis oblonga (Cadisch, 1932) (= Calpionella oblonga $\mathrm{Ca}-$ disch). See Catalano and Liguori (1970), pl. 5, figs. 3-6, 8, 9.

Calpionellopsis simplex (Colom, 1939) (= Calpionella simplex Colom). See Catalano and Liguori (1970), pl. 5, figs. 1, 2, 7.

Colomiella mexicana Bonet, 1956. See Ross and McNulty (1981), pl. 1, fig. 12; Longoria (1974), pl. 27, fig. 9.

Crassicollaria brevis Remane, 1962. See Remane (1964) pl. 2, figs. $1-18$; pl. 5, figs. 12-15.

Lorenziella hungarica Knauer and Nagy, 1963. See Catalano and Liguori (1970), pl. 5, figs. 16-19.

Remaniella cadischiana (Colom, 1948) ( = Tintinnopsella cadischiana Colom). See Catalano and Liguori (1970), pl. 3, figs. 6, 8, 13, 17; text-figs. $14 \mathrm{~b}$, c.

Remaniella "dadayi" (Knauer, 1963) (= Calpionellites dadayi Knauer). See Catalano and Liguori (1970), pl. 3,figs. 14-16; text-figs. $14 \mathrm{~d}, \mathrm{~g}$.

Remaniella ferasini (Catalano, 1965) (= Calpionellites ferasini Catalano). See Catalano and Liguori (1970), pl. 3, figs. 1-5; text-fig. 14a.

Tintinnopsella carpathica (Murgeanu and Filipescu, 1933) (= Calpionella carpathica Murgeanu and Filipescu). See Remane (1964), pl. 4 ; pl. 5, figs. 23-25; text-figs. $16,17 \mathrm{a}-\mathrm{c}$.

Tintinnopsella longa (Colom, 1939) (= Calpionella longa Colom). See Catalano and Liguori (1970), pl. 4, figs. 6, 7, 11-14.

\section{Planktonic Foraminifers}

Archaeoglobigerina blowi Pessagno, 1967. See Pessagno (1967), pl. 59, figs. 1-10; pl. 94, figs. $2,3$.

Archaeoglobigerina cretacea (d'Orbigny, 1840) (= Globigerina creta cea d'Orbigny). See Pessagno (1967), pl. 70, figs. 3-8; pl. 94, figs. 4,5 .

Dicarinella asymetrica (Sigal, 1952) (= Globotruncana asymmetrica Sigal). See Robaszynski and Caron (1979b), pls. 51, 52.

Dicarinella concavata (Brotzen, 1934) (= Rotalia concavata Brotzen). See Robaszynski and Caron (1979b), pls. 54, 55.

Dicarinella primitiva (Dalbiez, 1955) (= Globotruncana primitiva $\mathrm{Dal}$ biez). See Robaszynski and Caron (1979b), pl. 60.

\footnotetext{
3 In alphabetic order by genera and species, and listing reference illustrations.
}

Favusella tardita (Antonova). See Grigelis and Gorbatchik (1980), pl. 1 , fig. 8 .

Favusella washitensis (Carsey, 1926) (= Globigerina washitensis Carsey). See Grigelis and Gorbatchik (1980), pl. 1, fig. 9.

Globigerinelloides algerianus Cushman and Ten Dam, 1948. See Longoria (1974), pl. 6, figs. 1-18.

Globigerinelloides alvarezi (Eternod Olvera, 1959) $(=$ Planomalina alvarezi Eternod Olvera). See Sliter (1968), pl. 15, figs. 1, 2.

Globigerinelloides aptiense Longoria, 1974. See Longoria (1974), pl. 4, figs. 9, 10; pl. 8, figs. 4-6, 17, 18.

Globigerinelloides asper (Ehrenberg, 1854) (= Phanerostomum asperum Ehrenberg). See Pessagno (1967), pl. 60, figs. 4, 5.

Globigerinelloides barri (Bolli, Loeblich, and Tappan) (= Biglobigerinella barri Bolli, Loeblich, and Tappan). See Longoria (1974), pl. 4 , figs. $1-3,8$.

Globigerinelloides bentonensis (Morrow, 1934) (= Anomalina bentonensis Morrow). See Pessagno (1967), pl. 76, figs. 10, 11.

Globigerinelloides blowi (Bolli, 1959) (= Planomalina blowi Bolli). See Longoria (1974), pl. 4, figs. 15, 16; pl. 11, figs. 12, 13.

Globigerinelloides caseyi (Bolli, Loeblich, and Tappan, 1957) (= Planomalina caseyi Bolli, Loeblich, and Tappan). See Pessagno (1967), pl. 49, figs. 2-5.

Globigerinelloides duboisi (Chevalier, 1961) $(=$ Globigerinella duboisi Chevalier). See Longoria (1974), pl. 4, figs. 15, 16; pl. 11, figs. 12, 13.

Globigerinelloides ferreolensis (Moullade, 1961) ( = Biticinella ferreolensis Moullade). See Longoria (1974), pl. 5, figs. 7-8; pl. 8, figs. $1-3,8-15$; pl. 14 , figs. 7,8 ; pl. 27 , figs. $3,5,12$.

Globigerinelloides gottisi (Chevalier, 1961) (= Globigerinella gottisi Chevalier). See Longoria (1974), pl. 7, figs. 7, 8, 10-13.

Globigerinelloides maridalensis (Bolli, 1959) (= Planomalina maridalensis Bolli). See Longoria (1974), pl. 9, figs. 4-7, 10-13; pl. 27, fig. 18.

Globigerinelloides volutus (White, 1928) (= Globigerina voluta White). See Pessagno (1967), pl. 62, figs. 9-11; pl. 100, fig. 9.

Globotruncana arca (Cushman, 1926) (= Pulvinulina arca Cushman). See Pessagno (1967), pl. 79, figs. 5-8; pl. 90, figs. 6-8; pl. 96, figs. $7,8,17$.

Globotruncana caliciformis Vogler, 1941. See Ellis and Messina, as Globotruncana linnei calciformis Vogler.

Globotruncana elevata (Brotzen, 1934) (= Rotalia elevata Brotzen). See Pessagno (1967), pl. 78, figs. 12-14; pl. 80, figs. 1-6; pl. 81, figs. 9-14; pl. 93, figs. $1-5,8$.

Globotruncana fornicata Plummer, 1931. See Pessagno (1967), pl. 63, figs. $1-9$; pl. 80, figs. 7-9; pl. 96, figs. 3,4 .

Globotruncana linneiana (d'Orbigny, 1939) (= Rosalina linneiana d'Orbigny). See Pessagno (1967), pl. 72, figs. 1-4, 7-9; pl. 97, figs. 11-13.

Globotruncana plummerae Gandolfi, 1955. See Pessagno (1967), pl. 66 , figs. 3-8; pl. 96 , fig. 9.

Globotruncana rosetta (Carsey, 1926) (= Globigerina rosetta Carsey). See Pessagno (1967), pl. 70, figs. 9-12; pl. 73, figs. 5-8; pl. 98, fig. 14; pl. 97, figs. 19-23.

Globotruncana stephensoni Pessagno, 1967. See Pessagno (1967), pl. 69 , figs. 1-7; pl. 96 , figs. 5,6 .

Globotruncana stuarti (de Lapparent, 1918) (= Rosalina stuarti de Lapparent). See Pessagno (1967), pl. 81, figs. 1-6.

Globotruncana stuartiformis Dalbiez, 1955. See Pesagno (1967), pl. 80, figs. 3-6; pl. 92, fig. 13; pl. 93, figs. 6, 7.

Globotruncana subspinosa Pessagno, 1962. See Premoli Silva and Boersma (1977), pl. 1, figs. 1a, b.

Globotruncana ventricosa White, 1946. See Pessagno (1967), pl. 75, figs. 21-26; pl. 79, figs. 9-14; pl. 95, figs. 10, 11; pl. 99, fig. 2.

Globotruncanella havanensis (Voorwijk, 1937) (= Globotruncana havanensis Voorwijk). See Pessagno (1967), pl. 84, figs. 1-3.

Globuligerina caucasica Gorbatchik and Poroshina, 1979. See Gorbatchik and Poroshina (1979), pls. 2, 3.

Globuligerina hoterivica (Subbotina, 1953) (= Globigerina hoterivica Subbotina). See Subbotina (1953), pl. 1, figs. 1a-4c.

Gubkinella graysonensis (Tappan, 1940) (= Globigerina graysonensis Tappan). See Longoria (1974), pl. 1, figs. 1-12.

Hedbergella amabilis Loeblich and Tappan, 1961. See Pessagno (1967), pl. 52, figs. 6-8.

Hedbergella delrioensis (Carsey, 1926) (= Globigerina delrioensis Carsey). See Robaszynski and Caron (1979a), pls. 22, 23. 
Hedbergella flandrini Porthault, 1970. See Robaszynski and Caron (1979a), pls. 24, 25.

Hedbergella gorbatchikae Longoria, 1974. See Longoria (1974), pl. 15, figs. 1-16.

Hedbergella infracretacea (Glaessner, 1937) $(=$ Globigerina infracretacea Glaessner). See Longoria (1974), pl. 13, fig. 9.

Hedbergella libyca Barr, 1972. See McNulty (1979), pl. 3, figs. 1-6.

Hedbergella luterbacheri Longoria, 1974. See Longoria (1974), pl. 19, figs. 21-23, 24-26; pl. 26, figs. 15-17.

Hedbergella occulta Longoria, 1974. See Longoria (1974), pl. 11, figs. 1-3, 7, 8; pl. 20, figs. 5-9, 17, 18.

Hedbergella planispira (Tappan, 1940) (= Globigerina planispira Tappan). See Robaszynski and Caron (1979a), pls. 27, 28.

Hedbergella rischi Moullade, 1974 ( = Hedbergella sp. aff. infracretacea). See Moullade (1966), pl. 8, figs. 6-16.

Hedbergella sigali Moullade, 1966. See Longoria (1974), pl. 21, figs. $6-8$; pl. 22, figs. 1-13.

Hedbergella similis Longoria, 1974. See Longoria (1974), pl. 16, figs. 10-21; pl. 18, figs. 12, 13; pl. 23, figs. 14-16.

Hedbergella simplex (Morrow, 1934) (= Hastigerinella simplex Morrow). See Robaszynski and Caron (1979a), pls. 29, 30.

Hedbergella trocoidea (Gandolfi, 1942) ( = Anomalina lorneiana var. trocoidea Gandolfi). See Longoria (1974), pl. 17, figs. 1-16; pl. 18, figs. 3-5.

Heterohelix globulosa (Ehrenberg, 1840) (= Textularia globulosa Ehrenberg). See Pessagno (1967), pl. 87, figs. 5-9, 11-13.

Heterohelix moremani (Cushman, 1938) (= Guembelina moremani Cushman). See Pessagno (1967), pl. 48, figs. 10, 11; pl. 89, figs. 1, 2.

Heterohelix pulchra (Brotzen, 1936) (= Guembelina pulchra Brotzen). See Pessagno (1967), pl. 87, fig. 4.

Heterohelix reussi (Cushman, 1938) (= Guembelina reussi Cushman). See Pessagno (1967), pl. 85, figs. 1-9; pl. 86, figs. 1, 2.

Marginotruncana canaliculata (Reuss, 1854) (= Rosalina canaliculata Reuss). See Pessagno (1967), pl. 74, figs. 5-8.

Marginotruncana coronata (Bolli, 1945) (= Globotruncana lapparenti subsp. coronata Bolli). See Robaszynski and Caron (1979b), pl. 62 .

Marginotruncana marginata (Reuss, 1845) (= Rosalina marginata Reuss). See Robaszynski and Caron (1979b), pls. 63, 64.

Marginotruncana pseudolinneiana Pessagno, 1967. See Robaszynski and Caron (1979b), pls. 67, 68.

Marginotruncana renzi (Gandolfi, 1942) (= Globotruncana renzi Gandolfi). See Robaszynski and Caron (1979b), pl. 69.

Marginotruncana schneegansi (Sigal, 1952) (= Globotruncana schneegansi Sigal). See Robaszynski and Caron (1979b), pl. 71.

Marginotruncana sigali (Reichel, 1950) (= Globotruncana /Globotruncana] sigali Reichel). See Robaszynski and Caron (1979b), pl. 72.

Marginotruncana sinuosa Porthault, 1970. See Robazsynski and Caron (1979b), pls. 74, 75 .

Planoglobulina carseyae (Plummer, 1931) (= Ventilabrella carseyae Plummer). See Pessagno (1967), pl. 87, figs. 10, 15, 16.

Planomalina cheniourensis (Sigal, 1952) (= Planulina cheniourensis Sigal). See Ross and McNulty (1981), pl. 1, figs. 10, 11 .

Planomalina buxtorfi (Gandolfi, 1942) (= Planulina buxtorfi Gandolfi). See Robaszynski and Caron (1979a), pl. 1, figs. 2-4.

Planomalina praebuxtorfi Wonders, 1975. See Robaszynski and Caron (1979a), pl. 1, fig. 1.

Praeglobotruncana aumalensis (Sigal, 1952) (= Globotruncana aumalensis Sigal). See Robaszynski and Caron (1979b), pl. 42.

Praeglobotruncana delrioensis (Plummer, 1931) $(=$ Globorotalia delrioensis Plummer). See Robaszynski and Caron (1979b), pl. 43.

Praeglobotruncana gibba Klaus, 1960. See Robaszynski and Caron (1979b), pls. 44, 45.

Praeglobotruncana stephani (Gandolfi, 1942) (= Globotruncana stephani Gandolfi). See Robaszynski and Caron (1979b), pl. 48.

Pseudoguembelina costulata (Cushman, 1938) (= Guembelina costulata Cushman). See Pessagno (1967), pl. 79, fig. 1; pl. 88, figs. 8, 9; pl. 90 , fig. 3.

Pseudotextularia elegans (Rzehak, 1891) (= Cuneolina elegans Rzehak). See Pessagno (1967), pl. 75, figs. 12-17; pl. 85, figs. 10, 11; pl. 88 , figs. $14-16$; pl. 89 , figs. 10,11 ; pl. 97 , fig. 18 ; pl. 98 , figs. 19, 20.
Racemiguembelina fructicosa (Egger, 1899) (= Guembelina fructicosa Egger). See Pessagno (1967), pl. 90, figs. 14, 15.

Rotalipora appenninica (Renz, 1936) (= Globotruncana appenninica Renz). See Robaszynski and Caron (1979a), pls. 4, 5.

Rotalipora balernaensis Gandolfi, 1957. See Sigal (1967), pl. 2, figs. 2, $4,5-8$.

Rotalipora brotzeni (Sigal, 1948) (= Thalmanninella brotzeni Sigal). See Robaszynski and Caron (1979a), pl. 6.

Rotalipora greenhornensis (Morrow, 1934) (= Globorotalia greenhornensis Morrow). See Robaszynski and Caron (1979a), pls. 12, 13.

Rotalipora montsalvensis Mornod, 1950. See Robaszynski and Caron (1979a), pl. 15.

Rotalipora praebalernaensis Sigal, 1967. See Sigal (1967), pl. 1, figs. 1-12; pl. 2, figs. 1, 3.

Rotalipora subticinensis (Gandolfi, 1957) (= Ticinella subticinensis Gandolfi). See Robaszynski and Caron (1979a), pl. 19.

Rotalipora ticinensis (Gandolfi, 1942) (= Globotruncana ticinensis Gandolfi). See Robaszynski and Caron (1979a), pl. 20.

Rugoglobigerina hexacamerata Brönnimann, 1952. See Pessagno (1967), pl. 74 , fig. 4 ; pl. 91 , figs. 5-7.

Rugoglobigerina rugosa (Plummer, 1927) (= Globigerina rugosa Plummer). See Pessagno (1967), pl. 75, figs. 2, 3; pl. 101, figs. 8, 9.

Rugotruncana subcircumnodifer (Gandolfi, 1955) (= Globotruncana [Rugoglobigerina] circumnodifer subcircumnodifer Gandolfi). See Pessagno (1967), pl. 62, figs. 14-16; pl. 74, figs. 1-3.

Schackoina cenomana (Schacko, 1897) (= Siderolina cenomana Schacko). See Pessagno (1967), pl. 48, fig. 6.

Ticinella bejaouaensis Sigal, 1966. See Longoria (1974), pl. 18, figs. 1, 2; pl. 19, figs. 9-16; pl. 21, figs. 9-16.

Ticinella breggiensis (Gandolfi, 1942) (= Anomalina breggiensis Gandolfi). See Longoria (1974), pl. 25, figs. 7, 14-16.

Ticinella praeticinensis Sigal, 1966. See Sigal (1966), pl. 2, figs. 3a-8b; pl. 3 , figs. $1 \mathrm{a}-6 \mathrm{~b}$.

Ticinella primula Luterbacher, 1963. See Longoria (1974), pl. 25, figs. 1-6; pl. 26, figs. 12-14.

Ticinella raynaudi Sigal, 1966. See Sigal (1966), pl. 5, figs. 10a, b; pl. 6 , figs. 1a-5.

Ticinella roberti (Gandolfi, 1942) (= Anomalina roberti Gandolfi). See Longoria (1974), pl. 12, figs. 1-11.

Ticinella transitoria Longoria, 1974. See Longoria (1974), pl. 21, figs. 9-11, 14-16.

Whiteinella archaeocretacea Pessagno, 1967. See Pessagno (1967), pl. 51, figs. 2-4; pl. 54, figs. 19-21, 22-25; pl. 100, fig. 8 .

\section{APPENDIX B}

\section{Taxonomic Notes}

Globuligerina sp. 1. Globigerinid with a flat trochospire; outline subrectangular, compact, only very slightly lobate. Three globular chambers in the last whorl, rapidly increasing in size; inner spire very short. Sutures radial, depressed. Umbilicus obscure, but small and only slightly depressed. Aperture a low arch, umbilical, interiomarginal. This species differs from Globuligerina hoterivica (Subbotina) in having only three chambers in the last whorl, which increase rapidly in size, and a much lower trochospire. It differs from Globuligerina sp. 2 (see the following entry) in having a more compact, subrectangular outline and a smaller umbilicus.

Globuligerina sp. 2. Globigerinid with a flat trochospire, triangular in outline, and lobate. Three and one fourth subglobular chambers in the last whorl, increasing rapidly in size; inner spire very small. Sutures radial, slightly depressed. Umbilicus obscure, small. Aperture umbilical, unclear in all specimens, possibly a low arch. Globuligerina sp. 2 is similar to the form illustrated by Roesler et al. (1979) as Hedbergella? sp. aff. Clavihedbergella simplex as illustrated by Fuchs in 1971 (pl. 10, fig. 6).

Hedbergella? sp. Flat trochospire with four subglobular chambers in the last whorl, gradually increasing in size, separated by radial, slightly depressed sutures. Inner spire very short. The last chamber is displaced toward the umbilical side. Aperture a low elongate arch, umbilical-extraumbilical, straddling asymmetrically the periphery. In shape and cameral number it is similar to the holotype of Globigerinelloides primitivus Fuchs (1971) illustrated in pl. 9, fig. 27. 
Hedbergella? sp. 2. Flat trochospire with five subglobular chambers in the last whorl. Sutures radial, slightly depressed. Other properties not visible. It shows some similarities to the specimen illustrated by Sigal (1979, pl. 1, fig. 30) as Clavihedbergella eocretacica Neagu. Remarks. The species described above occur in general with Globuligerina hoterivica (Subbotina) and in some cases with Globuligerina cf. caucasica Gorbatchik and Poroshina, and specifically in two samples from Site 535, 535-57-7, 56-59 cm and 535-70-1, 110-111 cm. According to recent literature (Grigelis and Gorbatchik, 1980; Sigal, 1979; Roesler et al., 1979), the species of this group from Sample
535-57-7, 56-59 $\mathrm{cm}$ imply upper Hauterivian. This is in agreement with nannofossil data (see Watkins and Bowdler, this volume). The occurrence of the same species in Sample 535-70-1, 110-111 cm is not consistent with the lower Valanginian assignment based on both calpionellids and calcareous nannofossils. The contradiction may result from inadequate knowledge of the range of these hitherto rarely reported globigerinids, but it may be that the calpionellids and calcareous nannofossils are reworked. The latter possibility seems most unlikely, but it is in character with the repeated reworking and mixing of the entire sedimentary sequence of Hole 535 . 


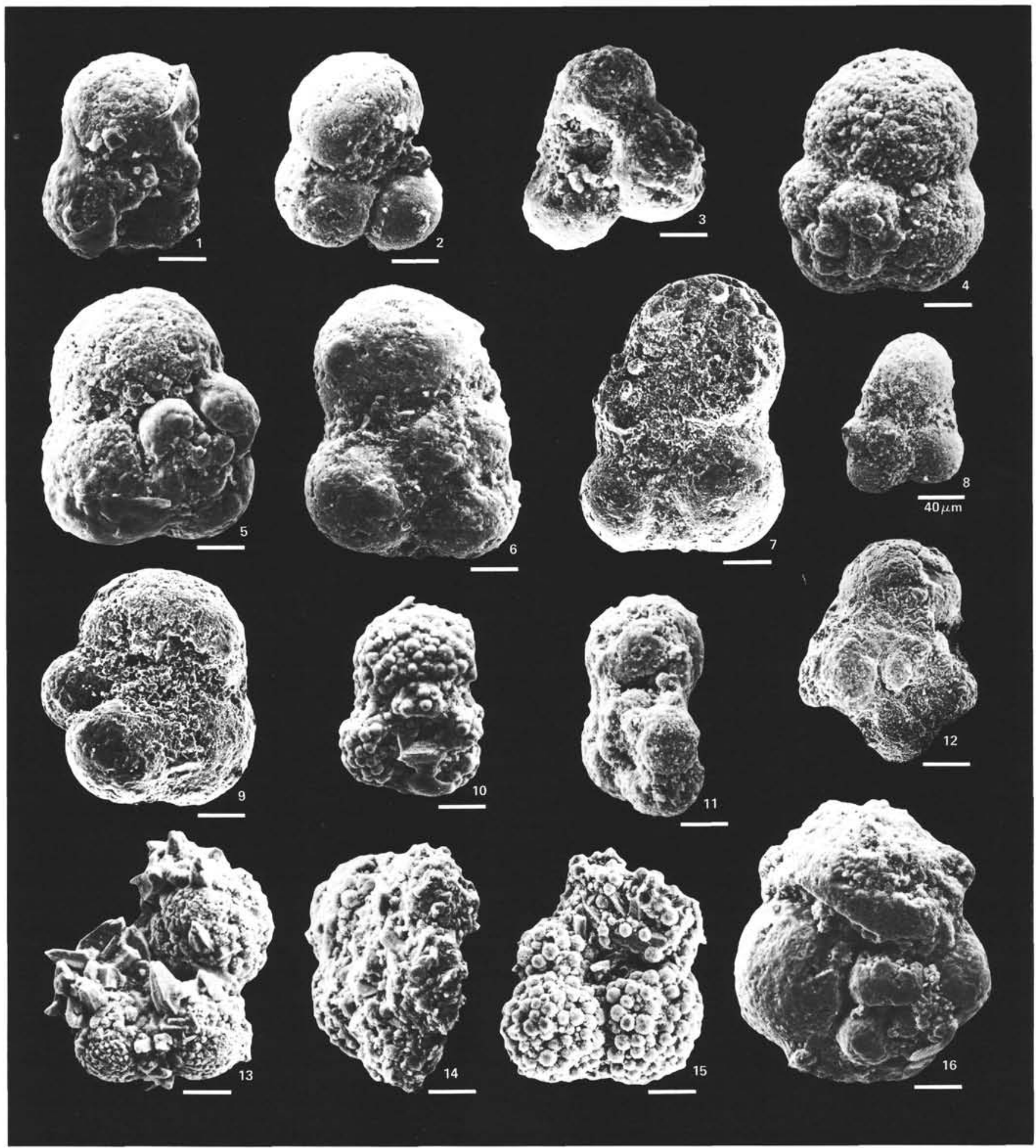

Plate 1. All specimens are pyritized internal molds, and the scale bar $=20 \mu \mathrm{m}$ unless otherwise indicated. 1, 2, 10. Globuligerina sp. 1, (1-2) Sample 535-57-7, 56-59 cm (1, spiral view; 2, umbilical view), (10) Sample 535-70-1, 110-111 cm, spiral view. 3. Globuligerina cf. caucasica Gorbatchik and Poroshina, Sample 535-57-5, 56-59 cm, umbilical view. 4, 5, 9, 16. Globuligerina hoterivica (Subbotina), Sample 535-57-7, 56-59 cm $(4,5,16)$ spiral view, (9) umbilical view. 6-8. Globuligerina sp. 2, Sample 535-57-7, 56-59 cm, (6) spiral view, (7) umbilical view, (8) umbilical view, scale bar $=40 \mu \mathrm{m}$. 11-13. Hedbergella? sp. 1, (11-12) Sample 535-57-7, 56-59 cm, (11, side view; 12, spiral view), (13) Sample 535-70-1, 110-111 cm, umbilical view. 14. Hedbergella? sp. 2, Sample 535-70-1, 110-111 cm, oblique side view. 15. Globuligerina cf. hoterivica (Subbotina), Sample 535-70-1, 110-111 cm, umbilical view. 

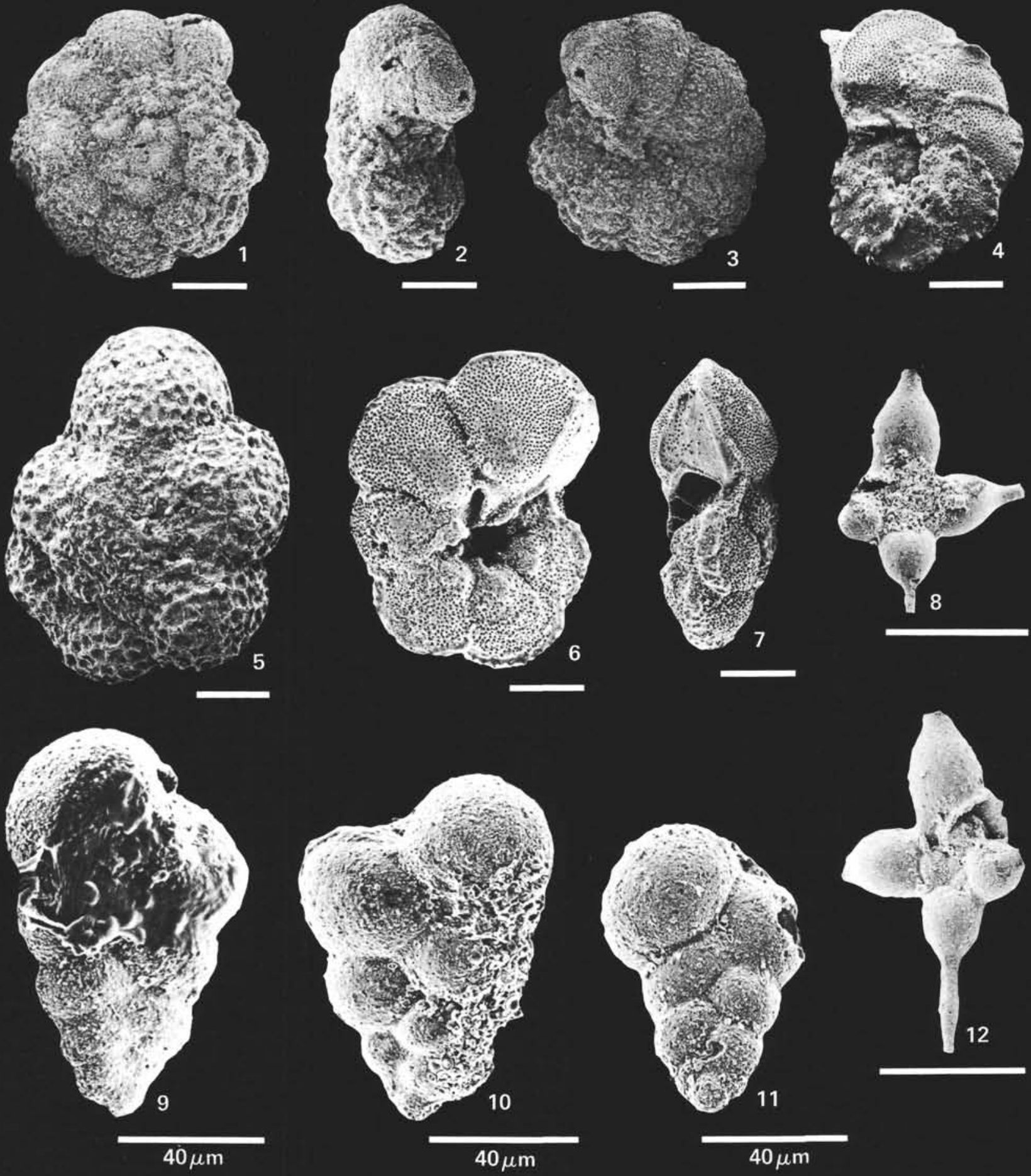

Plate 2. Scale bar $=100 \mu \mathrm{m}$ unless otherwise indicated. 1-3. Ticinella bejaouaensis Sigal, Sample 535-36-1, 80-82 cm, (1) spiral view, (2) side view, (3) umbilical view. 4. Planomalina buxtorfi (Gandolfi), Sample 538A-22-1, 18-20 cm. 5. Favusella washitensis (Carsey), Sample 535-36-1, 80-82 cm, spiral view. 6-7. Rotalipora appenninica (Renz), Sample 538A-22-1, 18-20 cm, (6) umbilical view, (7) side view. 8, 12. Schackoina cenomana (Schacko), Sample 538A-22-1, 18-20 cm. 9-11. Heterohelix moremani (Cushman), Sample 538A-22-1, 18-20 cm, scale bar $=40$ $\mu \mathrm{m}$. 


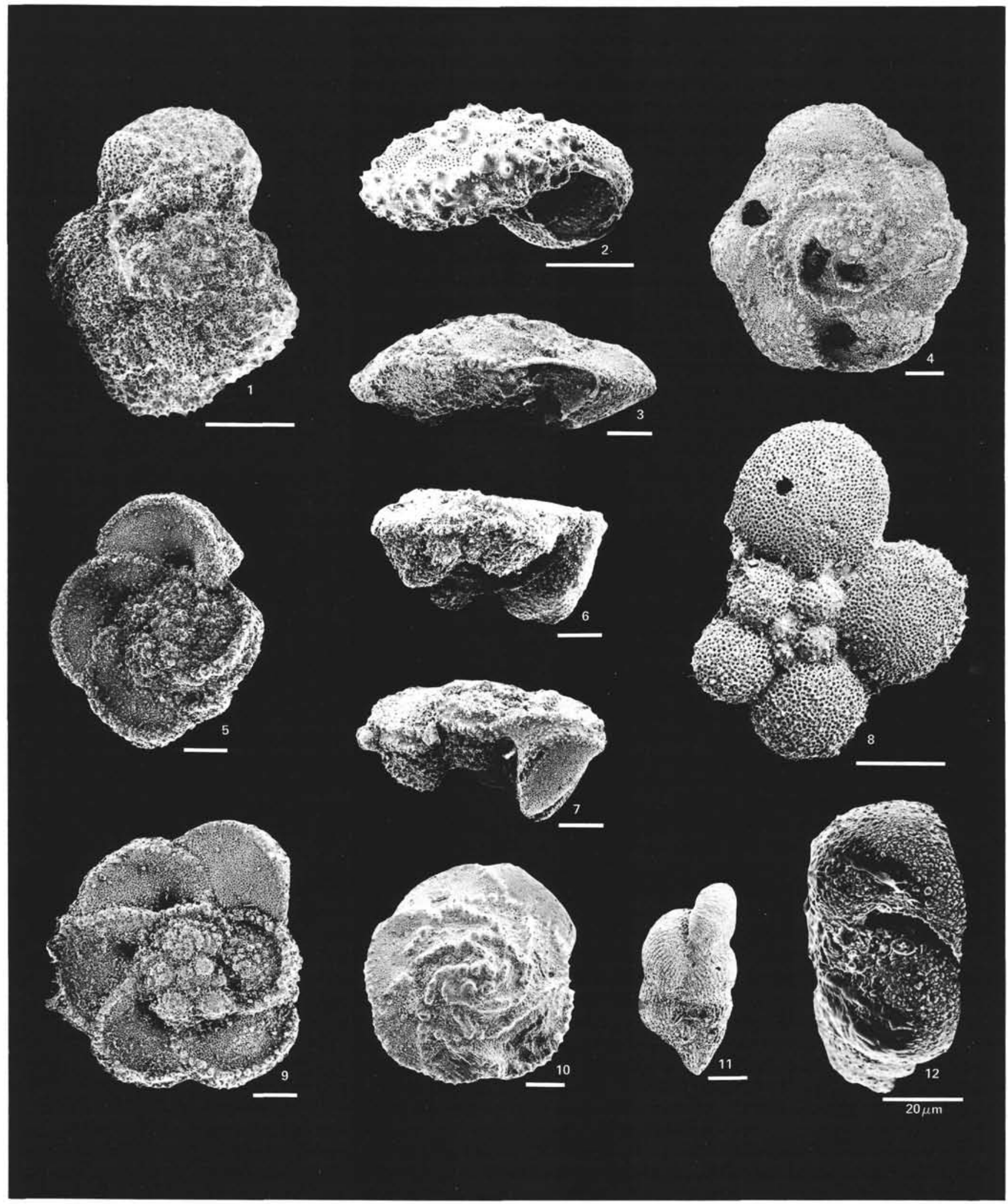

Plate 3. Scale bar $=100 \mu \mathrm{m}$ unless otherwise indicated. 1-2. Praeglobotruncana delrioensis (Plummer), Sample $538 \mathrm{~A}-22-1,18-20 \mathrm{~cm},(1) \mathrm{spiral}$ view, (2) side view. 3-4. Marginotruncana sinuosa Porthault, Sample 538A-21-4, 107-109 cm, (3) side view, (4) spiral view. 5-7, 9. Dicarinella concavata (Brotzen), Sample 538A-21-4, 78-80 cm, $(5,9)$ spiral view, $(6-7)$ side view. 8. Hedbergella flandrini Porthault, Sample 538A-21-4, 78-80 cm, spiral view. 10. Globotruncana stuartiformis Dalbiez, Sample 537-3-2, 50-52 cm, spiral view. 11. Pseudotextularia elegans (Rzehak), Sample 537-3-2, 50-52 cm. 12. Heterohelix moremani (Cushman), Sample 538A-22-1, 18-20 cm, apertural view of specimen figured in Pl. 2, Fig. 9, scale bar $=20 \mu \mathrm{m}$. 

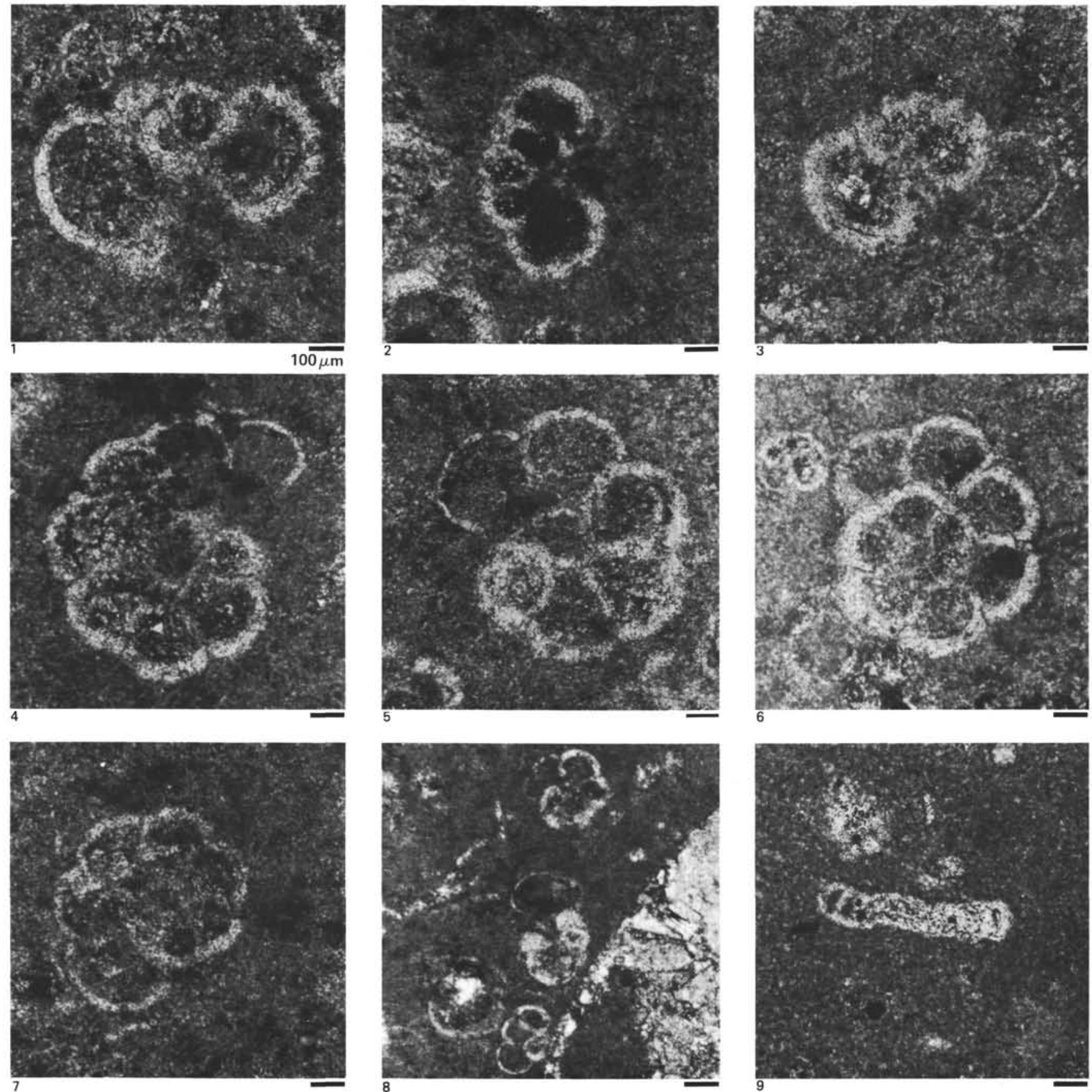

Plate 4. (Unless otherwise indicated, specimens are from Sample 535-43-3, 24-26 cm and are magnified $\times 143$.) 1. Hedbergella delrioensis (Carsey), axial section. 2. Hedbergella trocoidea (Gandolfi), axial section. 3. Ticinella bejaouaensis Sigal group, axial section. 4. Ticinella roberti (Gandolfi), umbilical section. 5. Ticinella cf. roberti (Gandolfi), umbilical section. 6-7. Ticinella bejaouensis Sigal, (6) spiral section, (7) umbilical section. 8. Hedbergellids, including H. trocoidea (Gandolfi), $\times 39$. 9. Spirillina sp., Sample 535-79-2, 25-28 cm, axial section. 


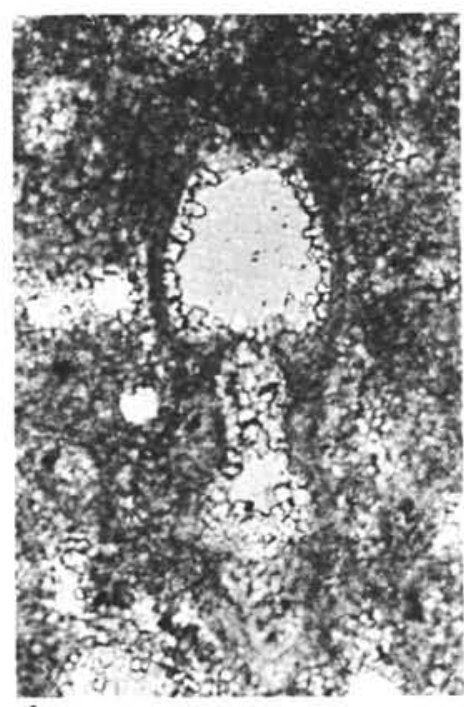

1

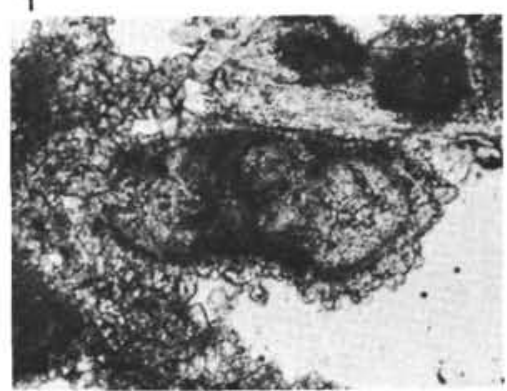

5

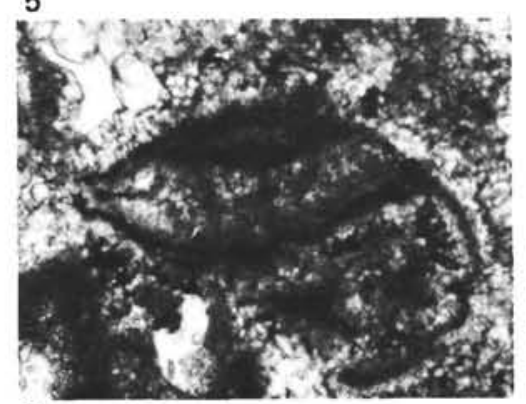

8

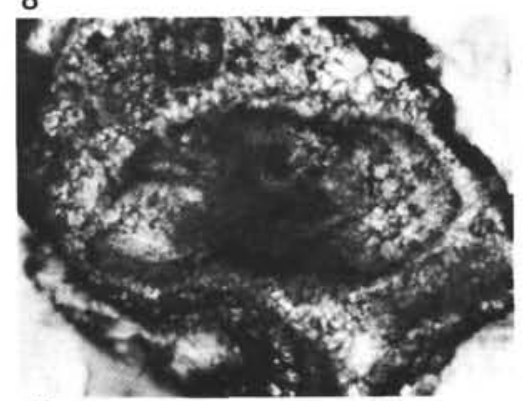

11

2
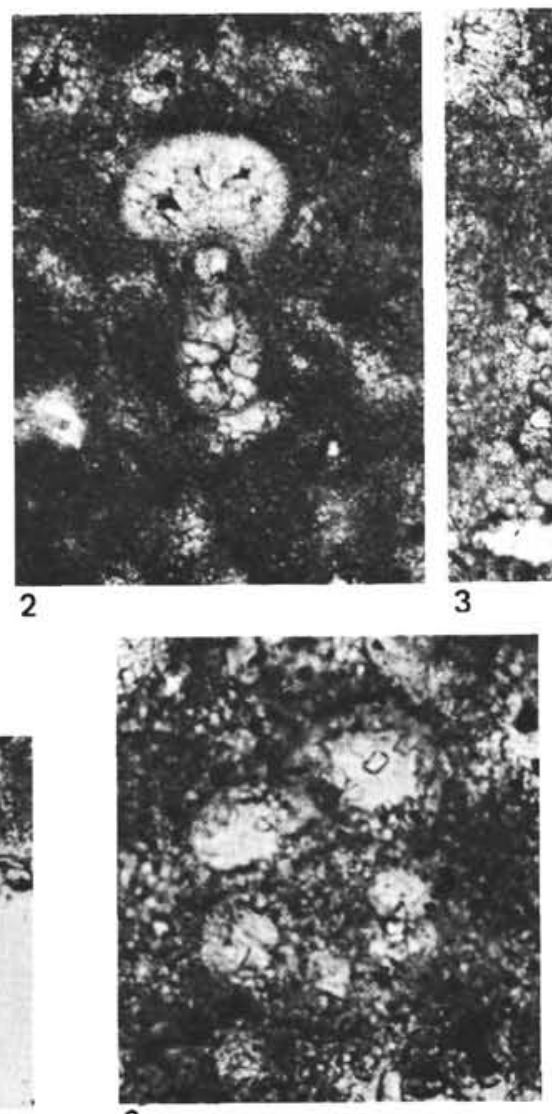

6

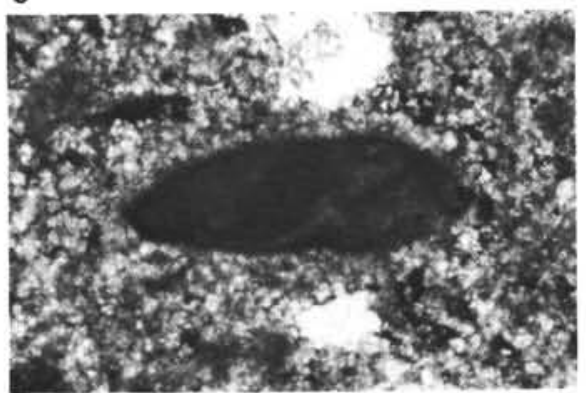

9

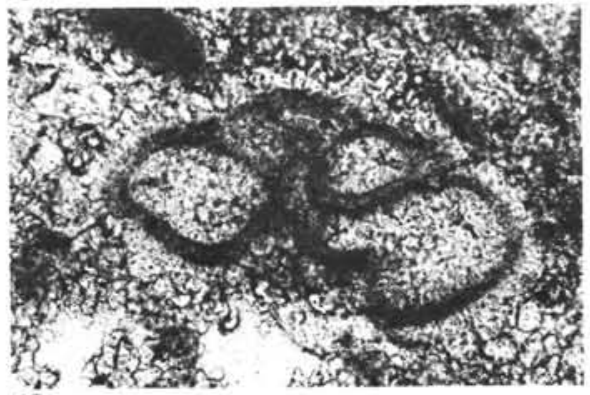

12

3
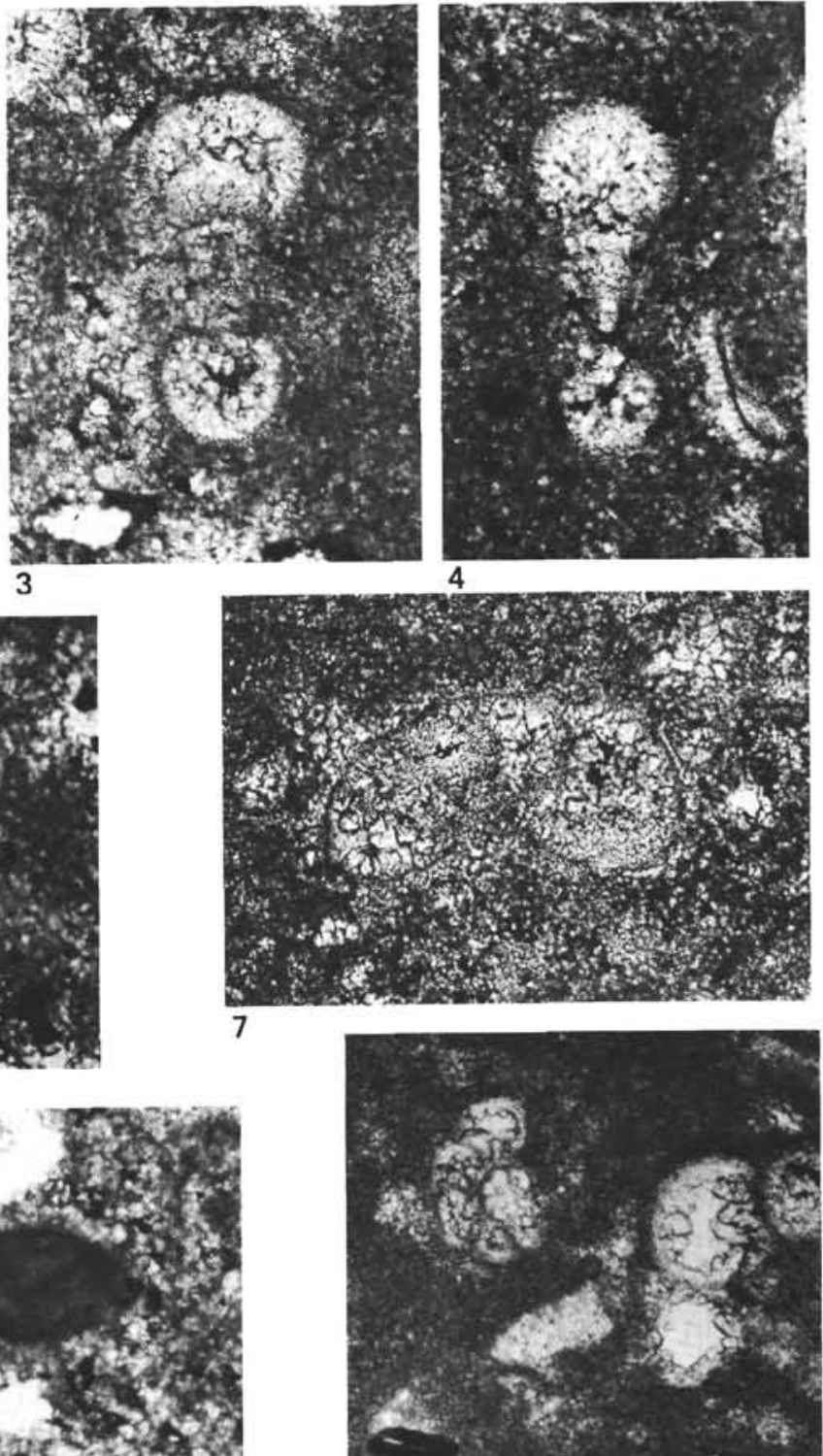

10

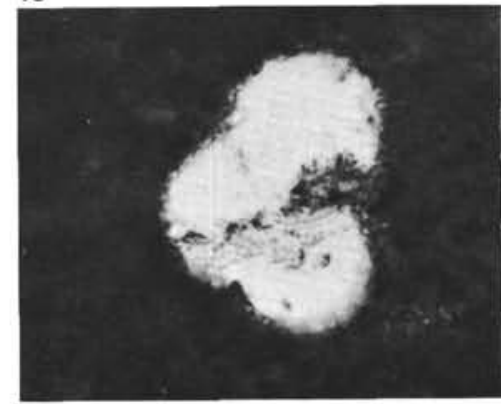

13

Plate 5. 1. Planomalina cheniourensis (Sigal), Sample $536-16-1,27-35 \mathrm{~cm}$, axial section, $\times 190$. 2-3. Globigerinelloides barri (Bolli, Loeblich and Tappan), Sample 536-16-1, 0-10 cm, (2) axial section, $\times 120,(3)$ axial section, $\times 200$. 4. Globigerinelloides ferreolensis Moullade, Sample $536-16-1,0-10 \mathrm{~cm}$, axial section, $\times 200$. 5. Rotalipora subticinensis (Gandolfi), Sample 536-11-1, 13-15 cm, axial section, $\times 75$. 6. Globigerinelloides sp., Sample 536-16-1, 27-35 cm, spiral section, $\times 300$. 7. Hedbergella? sp., Sample 536-16-1, 0-10 cm, oblique? axial section, $\times 190$. 8. Rotalipora sp. aff. $R$. ticinensis (Gandolfi), Sample 536-11-1, 13-15 cm, axial section, $\times 75$. 9. Rotalipora sp., Sample 536-11-1, $13-15 \mathrm{~cm}$, axial section, $\times 75$. 10. Hedbergellids, Sample 536-16-1, 0-10 cm, $\times 75$. 11. Rotalipora subticinensis (Gandolfi), Sample 536-11-1, $13-15 \mathrm{~cm}$, axial section, $\times 75$. 12. Praeglobotruncana stephani (Gandolfi)?, Sample 536-11-1, 13-15 cm, axial section, $\times 140$. 13. Globuligerina sp., Sample 537-9-2, 3-6 cm, $\times 300$. 


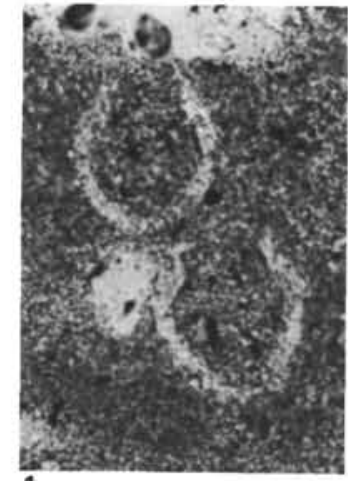

1

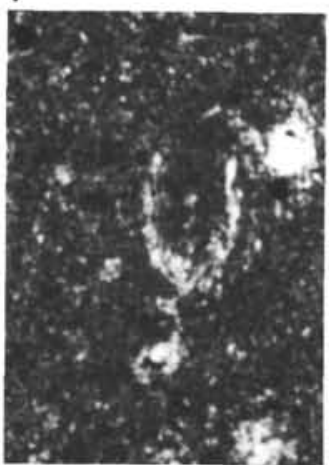

6

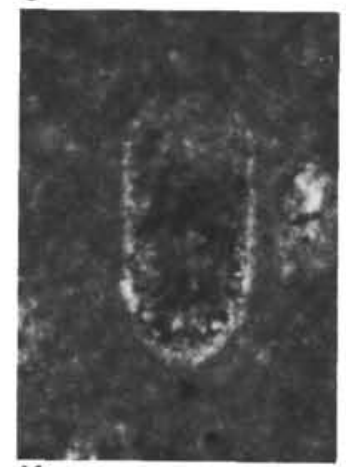

11

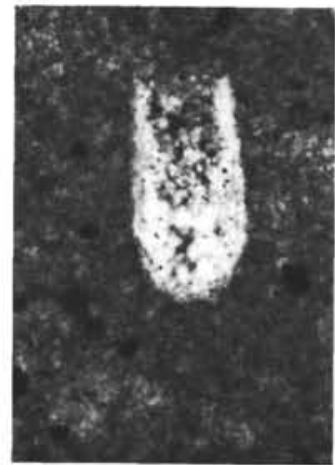

16

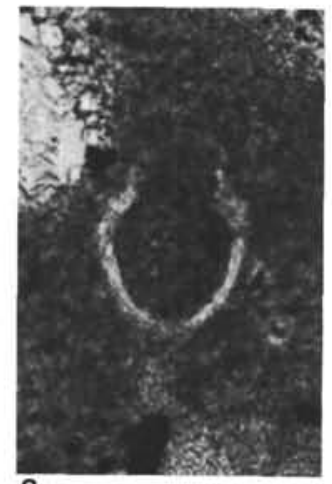

2

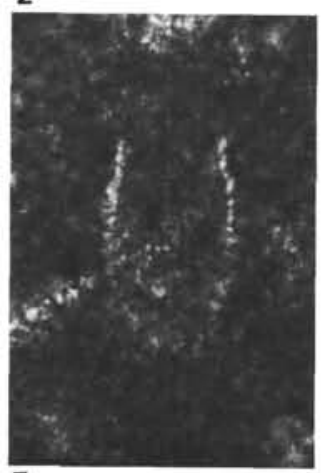

7

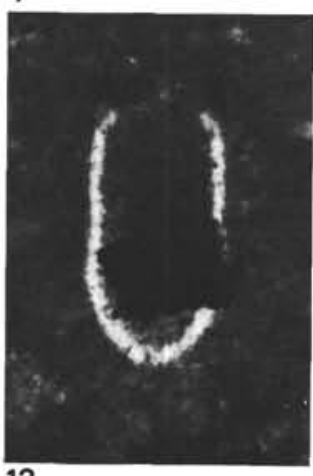

12

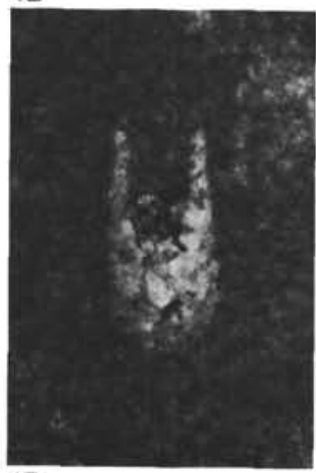

17

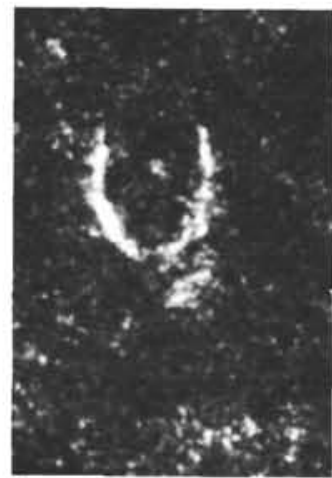

3

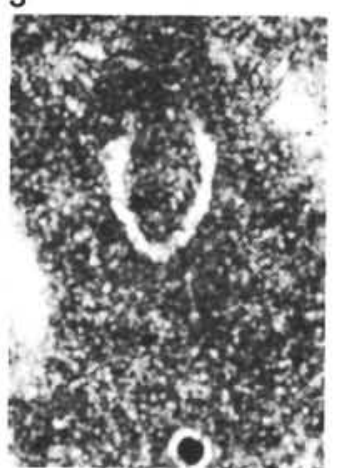

8

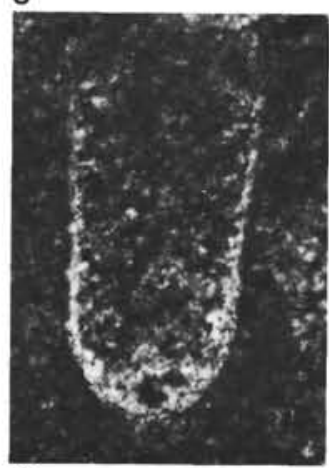

13

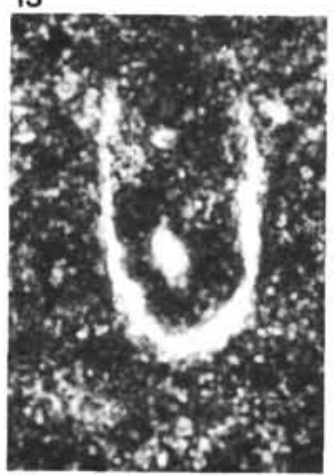

18

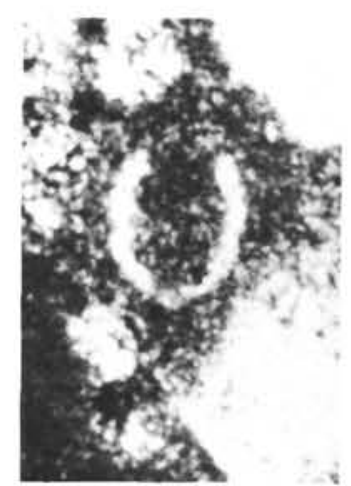

4

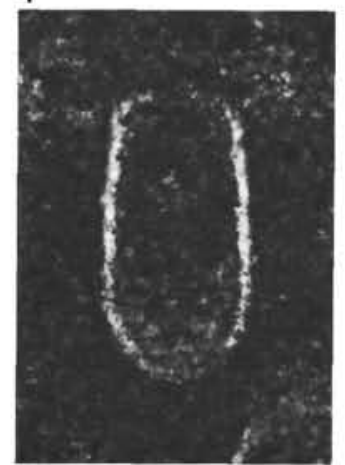

9

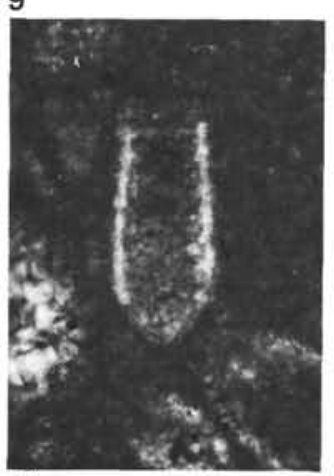

14

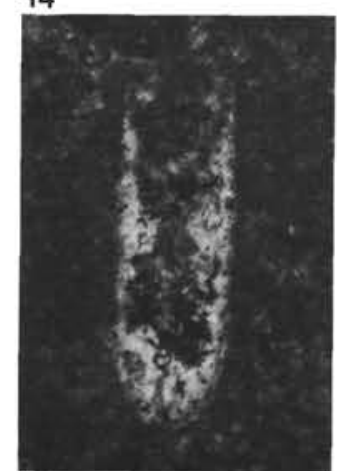

19

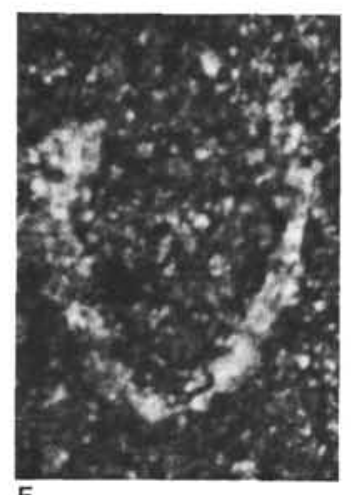

5

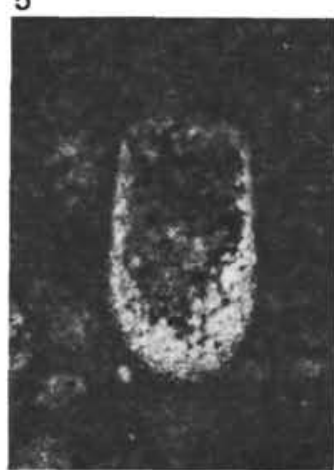

10

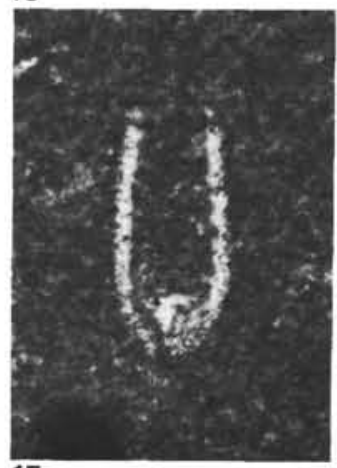

15

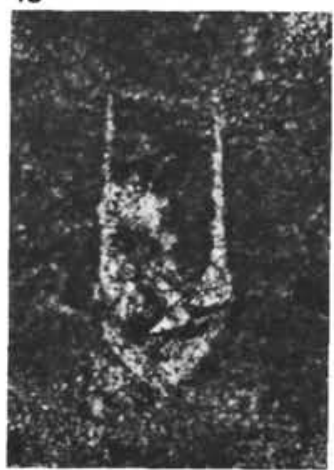

20

Plate 6. 1-2. Calpionella alpina Lorenz, $\times 300$, (1) Sample 538A-30-1, 3-4 cm, two specimens, (2) Sample 538A-30-1, 2-3 cm. 3-4. Calpionella alpina? Lorenz, $\times 300$, (3) Sample 538A-29-1, 11-12 cm, (4) Sample 538A-30-1, 2-3 cm. 5. Lorenziella hungarica Knauer and Nagy, Sample 538A-30-1, 1-2 cm, $\times 600$. 6. Calpionella elliptica Cadisch, Sample 538A-30-1, 1-2 cm, $\times 250$. 7. Calpionella elliptica? Cadisch, Sample $535-79-2,25-28 \mathrm{~cm}, \times 300$. 8. Crassicollaria brevis? Remane, Sample 538A-30-1, 1-2 cm, $\times 270$. 9-13. Calpionellopsis simplex (Colom), $\times 300$, (9-12) Sample 535-79-2, 25-28 cm, (13) Sample 535-75-3, 101-103 cm. 14-18. Calpionellopsis oblonga (Cadisch), (14-17) Sample $535-79-2,25-28 \mathrm{~cm}, \times 300,(18)$ Sample $538 \mathrm{~A}-27-1,12-13 \mathrm{~cm}, \times 380$. 19. Transitional form to Amphorellina sp., Sample 535-71-4, 39-42 cm, $\times 300$. 20. Colomiella mexicana Bonet, Sample $535-39-1,44-46 \mathrm{~cm}, \times 300$. 


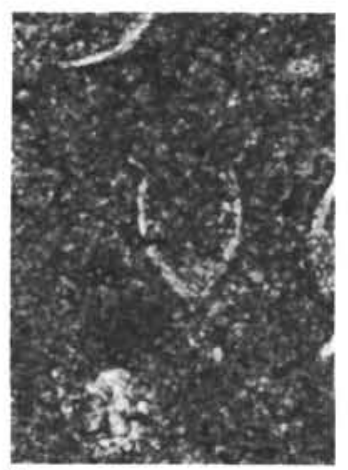

1

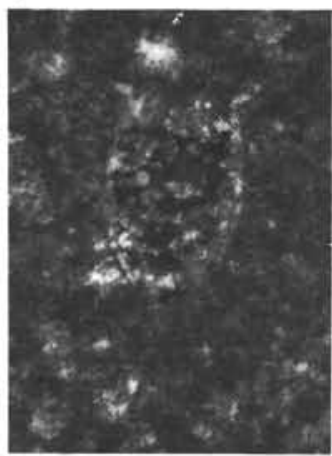

6

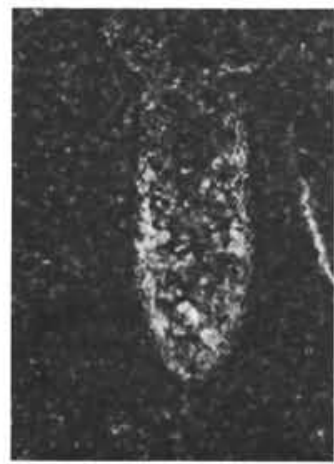

11

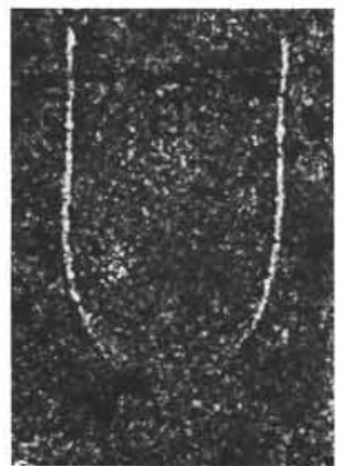

16

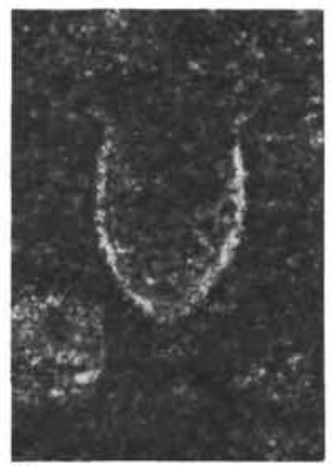

2

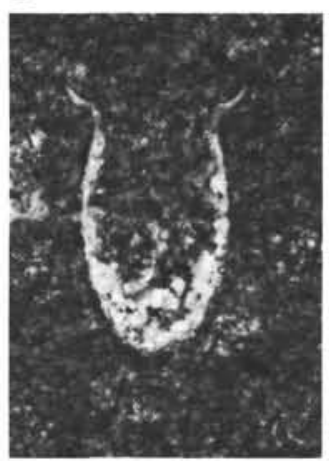

7

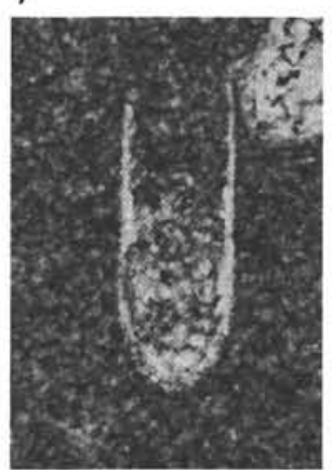

12

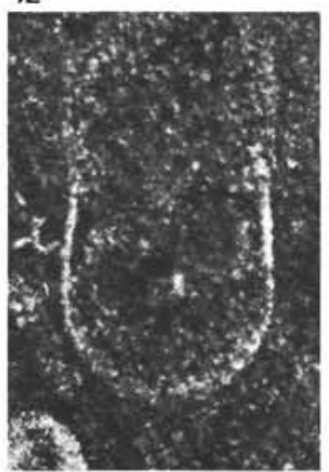

17

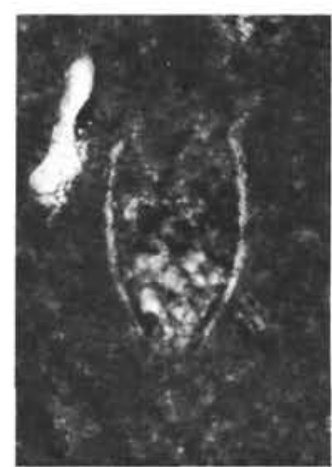

3

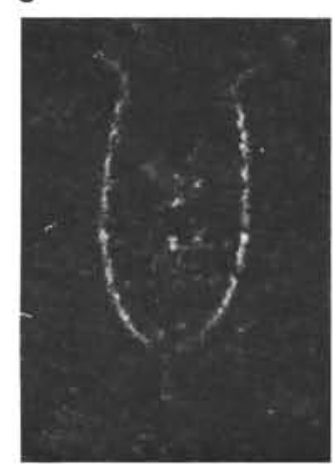

8

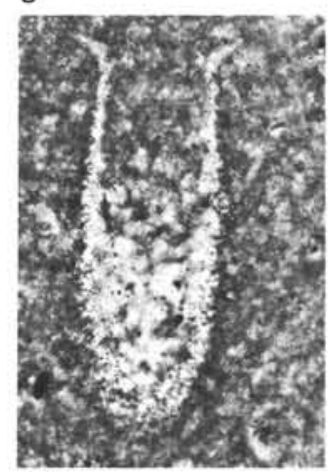

13

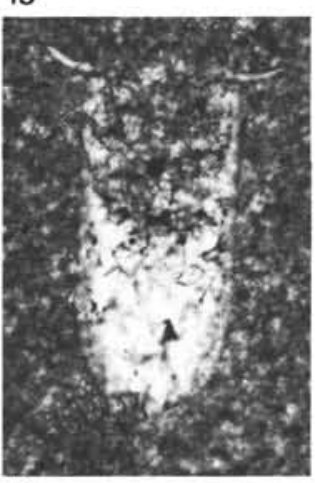

18

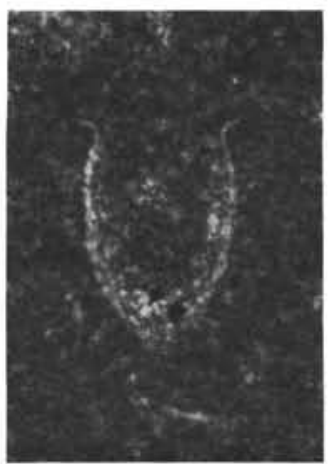

4

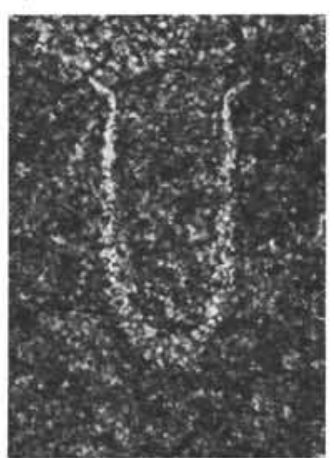

9

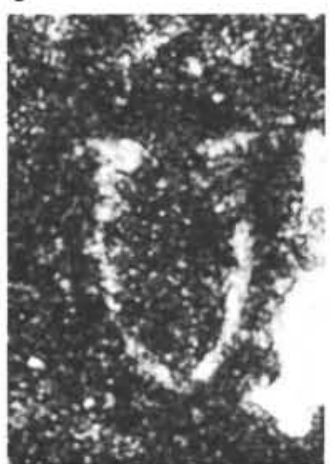

14

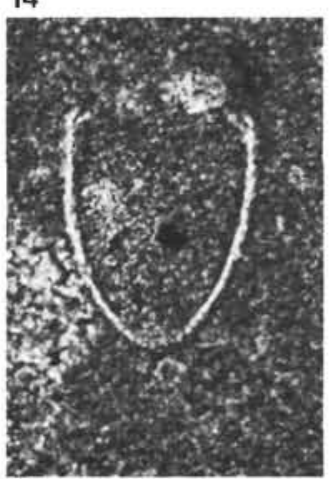

19

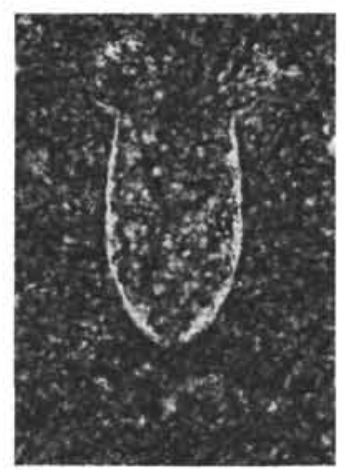

5

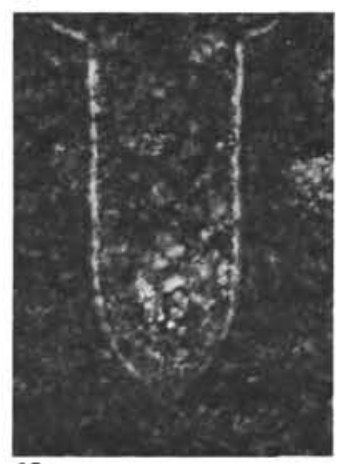

10

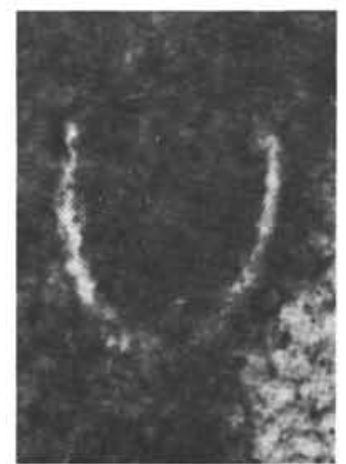

15

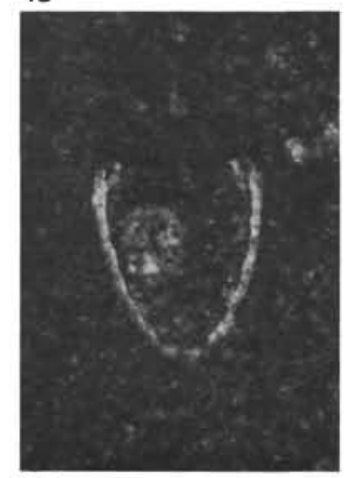

20

Plate 7. (Specimens magnified $\times 300$ unless otherwise indicated.) 1-2. Tintinnopsella cf. carpathica (Murgeanu and Filipescu), Sample 535-79-2, $25-28 \mathrm{~cm}$. 3-8. Tintinnopsella carpathica (Murgeanu and Filipescu), (3) Sample 535-70-4, 70-73 cm, (4, 8) Sample 535-79-2, 25-28 cm, (5, 7) Sample 535-71-4, 39-42 cm, (6) Sample 535-70-2, 1-5 cm. 9-12. Tintinnopsella longa (Colom), (9) Sample 535-76-1, 119-121 cm, (10-12) Sample 535-71-4, 39-42 cm. 13. Amphorellina sp., Sample 535-71-4, 39-42 cm, $\times 400$. 14. Remaniella ferasini? (Catalano), Sample 538A-29-1, 11-12 cm, $\times 400$. 15. Remaniella “dadayi" (Knauer), Sample 538A-24-1, 15-16 cm. 16-18. Remaniella cadischiana (Colom), (16-17) Sample 535-76-1, 119-121 cm, (18) Sample 535-71-4, 39-42 cm. 19-20 Calpionellites darderi (Colom), (19) Sample 535-76-1, 119-121 cm, (20) Sample $535-71-4,39-42 \mathrm{~cm}$. 